Cochrane Database of Systematic Reviews

\title{
Budesonide for maintenance of remission in Crohn's disease
} (Review)

Kuenzig ME, Rezaie A, Seow CH, Otley AR, Steinhart AH, Griffiths AM, Kaplan GG, Benchimol El

Kuenzig ME, Rezaie A, Seow CH, Otley AR, Steinhart AH, Griffiths AM, Kaplan GG, Benchimol El.

Budesonide for maintenance of remission in Crohn's disease.

Cochrane Database of Systematic Reviews 2014, Issue 8. Art. No.: CD002913.

DOI: 10.1002/14651858.CD002913.pub3.

www.cochranelibrary.com 
TABLE OF CONTENTS

ABSTRACT

PLAIN LANGUAGE SUMMARY

SUMMARY OF FINDINGS

BACKGROUND

OBJECTIVES

METHODS

RESULTS

Figure 1.

Figure 2.

DISCUSSION

AUTHORS' CONCLUSIONS

ACKNOWLEDGEMENTS

REFERENCES

\section{CHARACTERISTICS OF STUDIES}

DATA AND ANALYSES

Analysis 1.1. Comparison 1 Budesonide $6 \mathrm{mg}$ vs placebo, Outcome 1 Maintenance of clinical remission.

Analysis 1.2. Comparison 1 Budesonide $6 \mathrm{mg}$ vs placebo, Outcome 2 Change in CDAl from baseline.

Analysis 1.3. Comparison 1 Budesonide $6 \mathrm{mg}$ vs placebo, Outcome 3 Mean Time to Relapse (Days).

Analysis 1.4. Comparison 1 Budesonide $6 \mathrm{mg}$ vs placebo, Outcome 4 Withdrawals due to Treatment Failure.

Analysis 1.5. Comparison 1 Budesonide $6 \mathrm{mg}$ vs placebo, Outcome 5 Proportion of Patients with Treatment-Related Adverse Events at 12 Months.

Analysis 1.6. Comparison 1 Budesonide $6 \mathrm{mg}$ vs placebo, Outcome 6 Withdrawals due to Adverse Events.

Analysis 1.7. Comparison 1 Budesonide $6 \mathrm{mg}$ vs placebo, Outcome 7 Abnormal ACTH Stimulation Test.

Analysis 2.1. Comparison 2 Budesonide $3 \mathrm{mg}$ vs placebo, Outcome 1 Maintenance of Clinical Remission.

Analysis 2.2. Comparison 2 Budesonide $3 \mathrm{mg}$ vs placebo, Outcome 2 Change in CDAl from baseline.

Analysis 2.3. Comparison 2 Budesonide $3 \mathrm{mg}$ vs placebo, Outcome 3 Mean Time to Relapse (days).

Analysis 2.4. Comparison 2 Budesonide $3 \mathrm{mg}$ vs placebo, Outcome 4 Withdrawals due to Treatment Failure.

Analysis 2.5. Comparison 2 Budesonide $3 \mathrm{mg}$ vs placebo, Outcome 5 Proportion of Patients with Treatment-Related Adverse Events at 12 Months.

Analysis 2.6. Comparison 2 Budesonide $3 \mathrm{mg}$ vs placebo, Outcome 6 Withdrawals due to Adverse Events.

Analysis 2.7. Comparison 2 Budesonide $3 \mathrm{mg}$ vs placebo, Outcome 7 Abnormal ACTH Stimulation Test.

Analysis 3.1. Comparison 3 Withdrawals due to Adverse Events, Outcome 1 Budesonide (any dose) vs placebo.

Analysis 4.1. Comparison 4 Budesonide $6 \mathrm{mg}$ vs $3 \mathrm{mg}$, Outcome 1 Maintenance of Clinical Remissions.

Analysis 4.2. Comparison 4 Budesonide $6 \mathrm{mg}$ vs $3 \mathrm{mg}$, Outcome 2 Change in CDAl from baseline.

Analysis 4.3. Comparison 4 Budesonide $6 \mathrm{mg}$ vs $3 \mathrm{mg}$, Outcome 3 Mean Time to Relapse (days).

Analysis 4.4. Comparison 4 Budesonide $6 \mathrm{mg}$ vs $3 \mathrm{mg}$, Outcome 4 Withdrawals Due to Treatment Failure.

Analysis 4.5. Comparison 4 Budesonide $6 \mathrm{mg} v \mathrm{mg}$, Outcome 5 Proportion of Patients with Treatment-Related Adverse Events at 12 months.

Analysis 4.6. Comparison 4 Budesonide $6 \mathrm{mg} v s \mathrm{mg}$, Outcome 6 Withdrawals Due to Adverse Events.

Analysis 4.7. Comparison 4 Budesonide $6 \mathrm{mg}$ vs $3 \mathrm{mg}$, Outcome 7 Abnormal ACTH Stimulation Test.

Analysis 5.1. Comparison 5 Budesonide $9 \mathrm{mg}$ vs $6 \mathrm{mg}$, Outcome 1 Maintenance of Clinical Remission.

Analysis 5.2. Comparison 5 Budesonide $9 \mathrm{mg}$ vs $6 \mathrm{mg}$, Outcome 2 Change in CDAl from baseline.

Analysis 5.3. Comparison 5 Budesonide $9 \mathrm{mg}$ vs $6 \mathrm{mg}$, Outcome 3 Withdrawals Due to Treatment Failure.

Analysis 5.4. Comparison 5 Budesonide $9 \mathrm{mg} \mathrm{vs} 6 \mathrm{mg}$, Outcome 4 Proportion of Patients with Treatment-Related Adverse Events at 12 Months.

Analysis 5.5. Comparison 5 Budesonide $9 \mathrm{mg}$ vs $6 \mathrm{mg}$, Outcome 5 Withdrawals Due to Adverse Events.

Analysis 6.1. Comparison 6 Budesonide $9 \mathrm{mg} /$ day vs prednisolone $40 \mathrm{mg} /$ day (weaning), Outcome 1 Maintenance of Clinical Remission.

Analysis 6.2. Comparison 6 Budesonide $9 \mathrm{mg} /$ day vs prednisolone $40 \mathrm{mg} /$ day (weaning), Outcome 2 Withdrawals Due to Treatment Failure.

Analysis 6.3. Comparison 6 Budesonide $9 \mathrm{mg}$ /day vs prednisolone $40 \mathrm{mg} /$ day (weaning), Outcome 3 Withdrawals Due to Adverse Events. 
Analysis 6.4. Comparison 6 Budesonide $9 \mathrm{mg} /$ day vs prednisolone $40 \mathrm{mg} /$ day (weaning), Outcome 4 Abnormal ACTH Stimulation Test.

Analysis 7.1. Comparison 7 Budesonide $6 \mathrm{mg}$ vs mesalamine $3 \mathrm{~g} /$ day, Outcome 1 Maintenance of clinical remission.

Analysis 7.2. Comparison 7 Budesonide $6 \mathrm{mg}$ vs mesalamine $3 \mathrm{~g}$ /day, Outcome 2 Withdrawals Due to Treatment Failure. ........

Analysis 8.1. Comparison 8 Budesonide $6-9 \mathrm{mg}$ vs azathioprine $2.0-2.5 \mathrm{mg} / \mathrm{kg} / \mathrm{day}$, Outcome 1 Maintenance of clinical remission.

Analysis 8.2. Comparison 8 Budesonide 6-9 mg vs azathioprine $2.0-2.5 \mathrm{mg} / \mathrm{kg} / \mathrm{day}$, Outcome 2 Mean time to relapse.

Analysis 8.3. Comparison 8 Budesonide $6-9 \mathrm{mg}$ vs azathioprine $2.0-2.5 \mathrm{mg} / \mathrm{kg} / \mathrm{day}$, Outcome 3 Withdrawals due to treatment failure.

Analysis 8.4. Comparison 8 Budesonide $6-9 \mathrm{mg}$ vs azathioprine $2.0-2.5 \mathrm{mg} / \mathrm{kg} / \mathrm{day}$, Outcome 4 Withdrawls due to adverse events.

APPENDICES

WHAT'S NEW

HISTORY 
[Intervention Review]

\section{Budesonide for maintenance of remission in Crohn's disease}

M Ellen Kuenzig1,2, Ali Rezaie ${ }^{3}$, Cynthia H Seow 2,4 , Anthony R Otley 5 , A. Hillary Steinhart 6 , Anne Marie Griffiths 7 , Gilaad G Kaplan2,4, Eric I Benchimol1

1Division of Gastroenterology Hepatology \& Nutrition, The Children's Hospital of Eastern Ontario, Ottawa, Canada. 2Department of Community Health Sciences, University of Calgary, Calgary, Canada. ${ }^{3}$ Department of Medicine, Cedars-Sinai Medical Center, Los Angeles, California, USA. ${ }^{4}$ Department of Medicine, University of Calgary, Calgary, Canada. ${ }^{5} \mathrm{Head}$, Division of Gastroenterology, IWK Health Centre, Halifax, Canada. ${ }^{6}$ Department of Medicine, Division of Gastroenterology, Mount Sinai Hospital, Toronto, Canada. ${ }^{7}$ Division of Gastroenterology, Hepatology \& Nutrition, The Hospital for Sick Children, Toronto, Canada

Contact: Eric I Benchimol, Division of Gastroenterology Hepatology \& Nutrition, The Children's Hospital of Eastern Ontario, 401 Smyth Road, Ottawa, ON, K1H 8L1, Canada. ebenchimol@cheo.on.ca.

Editorial group: Cochrane IBD Group.

Publication status and date: Edited (no change to conclusions), published in Issue 4, 2020.

Citation: Kuenzig ME, Rezaie A, Seow CH, Otley AR, Steinhart AH, Griffiths AM, Kaplan GG, Benchimol El. Budesonide for maintenance of remission in Crohn's disease. Cochrane Database of Systematic Reviews 2014, Issue 8. Art. No.: CD002913. DOI: 10.1002/14651858.CD002913.pub3.

Copyright @ 2020 The Cochrane Collaboration. Published by John Wiley \& Sons, Ltd.

\section{A B S T R A C T}

\section{Background}

Corticosteroids are effective for induction, but not maintenance of remission in Crohn's disease. Significant concerns exist regarding the risk for adverse events, particularly when corticosteroids are used for long treatment courses. Budesonide is a glucocorticoid with limited systemic bioavailability due to extensive first-pass hepatic metabolism and is effective for induction of remission in Crohn's disease.

\section{Objectives}

To evaluate the efficacy and safety of oral budesonide for maintenance of remission in Crohn's disease.

\section{Search methods}

The following databases were searched from inception to 12 June 2014: PubMed, MEDLINE, EMBASE, CENTRAL, the Cochrane IBD/FBD Group Specialised Trial Register, and ClinicalTrials.gov. Reference lists of articles, as well as conference proceedings were manually searched.

\section{Selection criteria}

Randomized controlled trials comparing budesonide to a control treatment, or comparing two doses of budesonide, were included. The study population included patients of any age with quiescent Crohn's disease.

\section{Data collection and analysis}

Two independent investigators reviewed studies for eligibility, extracted data and assessed study quality using the Cochrane risk of bias tool. The primary outcome was maintenance of remission at various reported follow-up times during the study. Secondary outcomes included: time to relapse, mean change in CDAl, change in quality of life scores, adverse events and study withdrawal. We calculated the risk ratio (RR) and corresponding 95\% confidence interval $(95 \% \mathrm{Cl})$ for dichotomous outcomes and the mean difference (MD) and $95 \% \mathrm{Cl}$ for continuous outcomes. Data were analysed on an intention-to-treat basis. The $\mathrm{Chi}^{2}$ and $\mathrm{I}^{2}$ statistics were used to assess heterogeneity. Random-effects models were used to allow for expected clinical and statistical heterogeneity. The overall quality of the evidence supporting the primary outcome was assessed using the GRADE criteria. 


\section{Main results}

Twelve studies ( $n=1273$ patients) were included in the review: eight studies compared budesonide to placebo, one compared budesonide to 5-aminosalicylates, one compared budesonide to traditional systemic corticosteroids, one compared budesonide to azathioprine, and one compared two doses of budesonide. Nine studies used a controlled ileal release form of budesonide, while three used a pH-modified release formulation. Nine studies were judged to be at low risk of bias. Three studies were judged to be at high risk of bias due to blinding and one of these studies also had inadequate allocation concealment. Budesonide $6 \mathrm{mg}$ daily was no more effective than placebo for maintenance of remission at 3 months, 6 months or 12 months. At three months $64 \%$ of budesonide 6 mg patients remained in remission compared to $52 \%$ of placebo patients (RR $1.25,95 \% \mathrm{Cl} 1.00$ to $1.58 ; 6$ studies, 540 patients). A GRADE analysis indicated that the overall quality of the evidence for this outcome was low due to moderate heterogeneity $(12=56 \%)$ and sparse data (315 events). At six months $61 \%$ of budesonide $6 \mathrm{mg}$ patients remained in remission compared to $52 \%$ of placebo patients (RR $1.15,95 \% \mathrm{Cl} 0.95$ to $1.39 ; 5$ studies, 420 patients). A GRADE analysis indicated that the overall quality of the evidence for this outcome was moderate due to sparse data (238 events). At 12 months $55 \%$ of budesonide $6 \mathrm{mg}$ patients remained in remission compared to $48 \%$ of placebo patients (RR $1.13 ; 95 \% \mathrm{Cl} 0.94$ to $1.35 ; 5$ studies, 420 patients). A GRADE analysis indicated that the overall quality of the evidence for this outcome was moderate due to sparse data (215 events). Similarly, there was no significant benefit for budesonide $3 \mathrm{mg}$ compared to placebo at 6 and 12 months. There was no statistically significant difference in continued remission at 12 months between budesonide and weaning doses of prednisolone (RR $0.79 ; 95 \% \mathrm{Cl} 0.55$ to $1.13 ; 1$ study, 90 patients). A GRADE analysis indicated that the overall quality of the evidence supporting this outcome was low due to sparse data (51 events) and high risk of bias (no blinding). Budesonide $6 \mathrm{mg}$ was better than mesalamine $3 \mathrm{~g} /$ day at 12 months (RR 2.51, 95\% Cl 1.03 to $6.12 ; 1$ study, 57 patients). A GRADE analysis indicated that the overall quality of the evidence supporting this outcome was very low due to very sparse data (18 events) and high risk of bias (no blinding). There was no statistically significant difference in continued remission at 12 months between budesonide and azathioprine (RR $0.81 ; 95 \% \mathrm{Cl} 0.61$ to $1.08 ; 1$ study 77 patients). A GRADE analysis indicated that the overall quality of the evidence supporting this outcome was very low due to sparse data (55 events) and high risk of bias (single-blind and no allocation concealment). The use of budesonide $6 \mathrm{mg}$ resulted in slight improvements in CDAl scores when assessed at 6 months (MD -24.30, 95\% Cl -46.31 to -2.29) and 12 months (MD $-23.49,95 \% \mathrm{Cl}-46.65$ to -0.32 ) and mean time to relapse of disease (MD 59.93 days, $95 \% \mathrm{Cl} 19.02$ to 100.84). Mean time to relapse was significantly shorter for patients receiving budesonide than for those receiving azathioprine (MD -58.00, $95 \% \mathrm{Cl}-96.68$ to -19.32 ). Adverse events were not more common in patients treated with budesonide compared to placebo ( $6 \mathrm{mg}$ : RR $1.51,95 \% \mathrm{Cl} 0.90$ to $2.52 ; 3 \mathrm{mg}$ : RR $1.19,95 \% \mathrm{Cl} 0.63$ to 2.24 ). These events were relatively minor and did not result in increased rates of study withdrawal. Commonly reported treatment-related adverse effects included acne, moon facies, hirsutism, mood swings, insomnia, weight gain, striae, and hair loss. Abnormal adrenocorticoid stimulation tests were seen more frequently in patients receiving both $6 \mathrm{mg}(\mathrm{RR} 2.88,95 \% \mathrm{Cl} 1.72$ to 4.82 ) and $3 \mathrm{mg}$ daily ( $\mathrm{RR} 2.73,95 \% \mathrm{Cl} 1.34$ to 5.57$)$ compared to placebo.

\section{Authors' conclusions}

These data suggest budesonide is not effective for maintenance of remission in CD, particularly when used beyond three months following induction of remission. Budesonide does have minor benefits in terms of lower CDAI scores and longer time to relapse of disease. However, these benefits are offset by higher treatment-related adverse event rates and more frequent adrenocorticoid suppression in patients receiving budesonide.

\section{PLAIN LANGUAGE SUMARY}

\section{Budesonide for maintenance of remission in Crohn's disease}

Budesonide is a corticosteroid drug which is rapidly broken down by the liver, reducing corticosteroid-related side effects (e.g., moon face). Research showing that budesonide is effective in treating active Crohn's disease has led to clinical trials examining the effect of budesonide on reducing disease recurrence in non-active Crohn's disease.

This review identified 12 studies that included a total of 1273 participants. Eight studies compared budesonide with placebo (e.g. a sugar pill), one study compared budesonide to mesalamine (an anti-inflammatory drug), one study compared budesonide to traditional systemic corticosteroids, one compared budesonide to azathioprine (an immunosuppressive drug), and one compared two doses of budesonide. Pooled analyses show that budesonide $6 \mathrm{mg}$ daily was no more effective than placebo for maintenance of remission at 3 months ( 6 studies, 540 patients), 6 months ( 5 studies, 420 patients) or 12 months ( 5 studies, 420 patients). A pooled analysis showed that budesonide 3 mg daily was more effective than placebo for maintaining remission at 3 months (4 studies, 163 patients). However, there was no difference in continued remission rates between budesonide $3 \mathrm{mg} /$ day and placebo at 6 months ( 3 studies, 180 patients) or 12 months (5 studies, 442 patients). The overall quality of the evidence from the studies comparing budesonide to placebo was rated as moderate due to lack of precision of the results. One study (90 patients) found no difference in continued remission rates at 12 months between budesonide and prednisolone. The overall quality of the evidence from this study was rated as low due to lack of precision of results and low methodological quality. One study (77 patients) found no difference in continued remission rates at 12 months between budesonide and azathioprine.The overall quality of the evidence from this study was rated as very low due to lack of precision of results and low methodological quality. One study (57 patients) found that budesonide ( $6 \mathrm{mg} /$ day) was better than mesalamine for continued remission at 12 months. The overall quality of the evidence from this study was rated as very low due to lack of precision of results and low methodological quality. No differences in effectiveness were found for different doses or formulations of budesonide. The use of budesonide $6 \mathrm{mg} / \mathrm{day}$ resulted in slight improvements in Crohn's disease activity index (CDAI) scores when assessed at 6 months (5 studies, 420 patients) and 12 months 
(5 studies, 420 patients) and mean time to relapse of disease (4 studies, 171 patients). Mean time to relapse was significantly shorter for patients receiving budesonide than for those receiving azathioprine. Side effects were not more common in patients treated with budesonide compared to placebo. These side effects were relatively minor and did not result in increased rates of study withdrawal. Commonly reported treatment-related side effects included acne, round face, body hair growth, mood swings, insomnia, weight gain, stretch marks, and hair loss. Abnormal adrenocorticoid stimulation tests were seen more frequently in patients receiving both budesonide $6 \mathrm{mg}$ daily and $3 \mathrm{mg}$ daily compared to placebo. The results of this review suggest budesonide is not effective for maintenance of remission in Crohn's disease, particularly when used beyond three months following induction of remission. Budesonide does have minor benefits in terms of lower CDAl scores and longer time to relapse of disease. However, these benefits are offset by higher treatment-related side effect rates and more frequent adrenocorticoid suppression in patients receiving budesonide. 
SUMMARY OF FINDINGS

Summary of findings for the main comparison. Budesonide $6 \mathrm{mg}$ versus placebo for maintenance of remission in Crohn's disease

Budesonide $6 \mathrm{mg}$ versus placebo for maintenance of remission in Crohn's disease

Patient or population: patients with quiescent Crohn's disease

Settings: outpatients

Intervention: budesonide $6 \mathrm{mg}$ versus placebo

\begin{tabular}{|c|c|c|c|c|c|c|}
\hline \multirow[t]{3}{*}{ Outcomes } & \multicolumn{2}{|c|}{ Illustrative comparative risks ${ }^{\star}(95 \% \mathrm{Cl})$} & \multirow{3}{*}{$\begin{array}{l}\text { Relative effect } \\
(95 \% \mathrm{Cl})\end{array}$} & \multirow{3}{*}{$\begin{array}{l}\text { No of Partici- } \\
\text { pants } \\
\text { (studies) }\end{array}$} & \multirow{3}{*}{$\begin{array}{l}\text { Quality of the } \\
\text { evidence } \\
\text { (GRADE) }\end{array}$} & \multirow[t]{3}{*}{ Comments } \\
\hline & Assumed risk & Corresponding risk & & & & \\
\hline & Control & Budesonide $6 \mathrm{mg}$ versus placebo & & & & \\
\hline $\begin{array}{l}\text { Continued remission } \\
\text { at } 3 \text { months }\end{array}$ & 522 per $1000^{1}$ & $\begin{array}{l}\mathbf{6 5 2} \text { per } 1000 \\
(522 \text { to } 825)\end{array}$ & $\begin{array}{l}\text { RR } 1.25 \\
(1.00 \text { to } 1.58)\end{array}$ & $\begin{array}{l}540 \\
\text { (6 studies) }\end{array}$ & $\begin{array}{l}\oplus \oplus \oplus \ominus \\
\text { Low }^{2,3}\end{array}$ & \\
\hline $\begin{array}{l}\text { Continued remission } \\
\text { at } 12 \text { months }\end{array}$ & 476 per $1000^{1}$ & $\begin{array}{l}\mathbf{5 3 8} \text { per } 1000 \\
\text { ( } 447 \text { to } 643 \text { ) }\end{array}$ & $\begin{array}{l}\text { RR } 1.13 \\
\text { (0.94 to } 1.35)\end{array}$ & $\begin{array}{l}420 \\
\text { (5 studies) }\end{array}$ & $\begin{array}{l}\oplus \oplus \oplus \ominus \\
\text { Moderate }^{5}\end{array}$ & \\
\hline
\end{tabular}

${ }^{*}$ The basis for the assumed risk (e.g. the median control group risk across studies) is provided in footnotes. The corresponding risk (and its $95 \%$ confidence interval) is based on the assumed risk in the comparison group and the relative effect of the intervention (and its $95 \% \mathrm{Cl}$ ).

Cl: Confidence interval; RR: risk ratio

GRADE Working Group grades of evidence

High quality: Further research is very unlikely to change our confidence in the estimate of effect.

Moderate quality: Further research is likely to have an important impact on our confidence in the estimate of effect and may change the estimate.

Low quality: Further research is very likely to have an important impact on our confidence in the estimate of effect and is likely to change the estimate.

Very low quality: We are very uncertain about the estimate.

1 Control group risk estimates come from control arm of meta-analysis, based on included trials.

2 Unexplained heterogeneity $(12=56 \%)$

3 Sparse data (315 events).

4 Sparse data (238 events).

5 Sparse data (215 events). 
Summary of findings 2. Budesonide $3 \mathrm{mg}$ versus placebo for maintenance of remission in Crohn's disease

Budesonide $3 \mathrm{mg}$ versus placebo for maintenance of remission in Crohn's disease

Patient or population: patients with quiescent Crohn's disease

Settings: outpatients

Intervention: budesonide $3 \mathrm{mg}$ versus placebo

\begin{tabular}{|c|c|c|c|c|c|c|}
\hline \multirow[t]{3}{*}{ Outcomes } & \multicolumn{2}{|c|}{ Illustrative comparative risks* $(95 \% \mathrm{CI})$} & \multirow{3}{*}{$\begin{array}{l}\text { Relative effect } \\
(95 \% \mathrm{Cl})\end{array}$} & \multirow{3}{*}{$\begin{array}{l}\text { No of Partici- } \\
\text { pants } \\
\text { (studies) }\end{array}$} & \multirow{3}{*}{$\begin{array}{l}\text { Quality of the } \\
\text { evidence } \\
\text { (GRADE) }\end{array}$} & \multirow[t]{3}{*}{ Comments } \\
\hline & Assumed risk & Corresponding risk & & & & \\
\hline & Control & Budesonide $3 \mathrm{mg}$ versus placebo & & & & \\
\hline $\begin{array}{l}\text { Continued remission } \\
\text { at } 3 \text { months }\end{array}$ & 438 per $1000^{1}$ & $\begin{array}{l}\mathbf{5 6 5} \text { per } 1000 \\
(442 \text { to } 714)\end{array}$ & $\begin{array}{l}\text { RR } 1.29 \\
\text { (1.01 to } 1.63)\end{array}$ & $\begin{array}{l}263 \\
\text { (4 studies) }\end{array}$ & $\begin{array}{l}\oplus \oplus \oplus \ominus \\
\text { Moderate }^{2}\end{array}$ & \\
\hline $\begin{array}{l}\text { Continued remission } \\
\text { at } 12 \text { months }\end{array}$ & 400 per $1000^{1}$ & $\begin{array}{l}\mathbf{4 3 2} \text { per } 1000 \\
(348 \text { to } 536)\end{array}$ & $\begin{array}{l}\text { RR } 1.08 \\
(0.87 \text { to } 1.34)\end{array}$ & $\begin{array}{l}442 \\
\text { (5 studies) }\end{array}$ & $\begin{array}{l}\oplus \oplus \ominus \ominus \\
\text { Moderate } 4\end{array}$ & \\
\hline
\end{tabular}

*The basis for the assumed risk (e.g. the median control group risk across studies) is provided in footnotes. The corresponding risk (and its $95 \%$ confidence interval) is

based on the assumed risk in the comparison group and the relative effect of the intervention (and its $95 \% \mathrm{Cl}$ ).

Cl: Confidence interval; RR: risk ratio

GRADE Working Group grades of evidence

High quality: Further research is very unlikely to change our confidence in the estimate of effect.

Moderate quality: Further research is likely to have an important impact on our confidence in the estimate of effect and may change the estimate.

Low quality: Further research is very likely to have an important impact on our confidence in the estimate of effect and is likely to change the estimate.

Very low quality: We are very uncertain about the estimate.

${ }^{1}$ Control group risk estimates come from control arm of meta-analysis, based on included trials.

2 Sparse data (133 events).

3 Sparse data (84 events).

4 Sparse data (182 events).

Summary of findings 3. Budesonide $6 \mathrm{mg}$ versus budesonide $3 \mathrm{mg}$ for maintenance of remission in Crohn's disease

Budesonide $6 \mathrm{mg}$ versus budesonide $3 \mathrm{mg}$ for maintenance of remission in Crohn's disease 


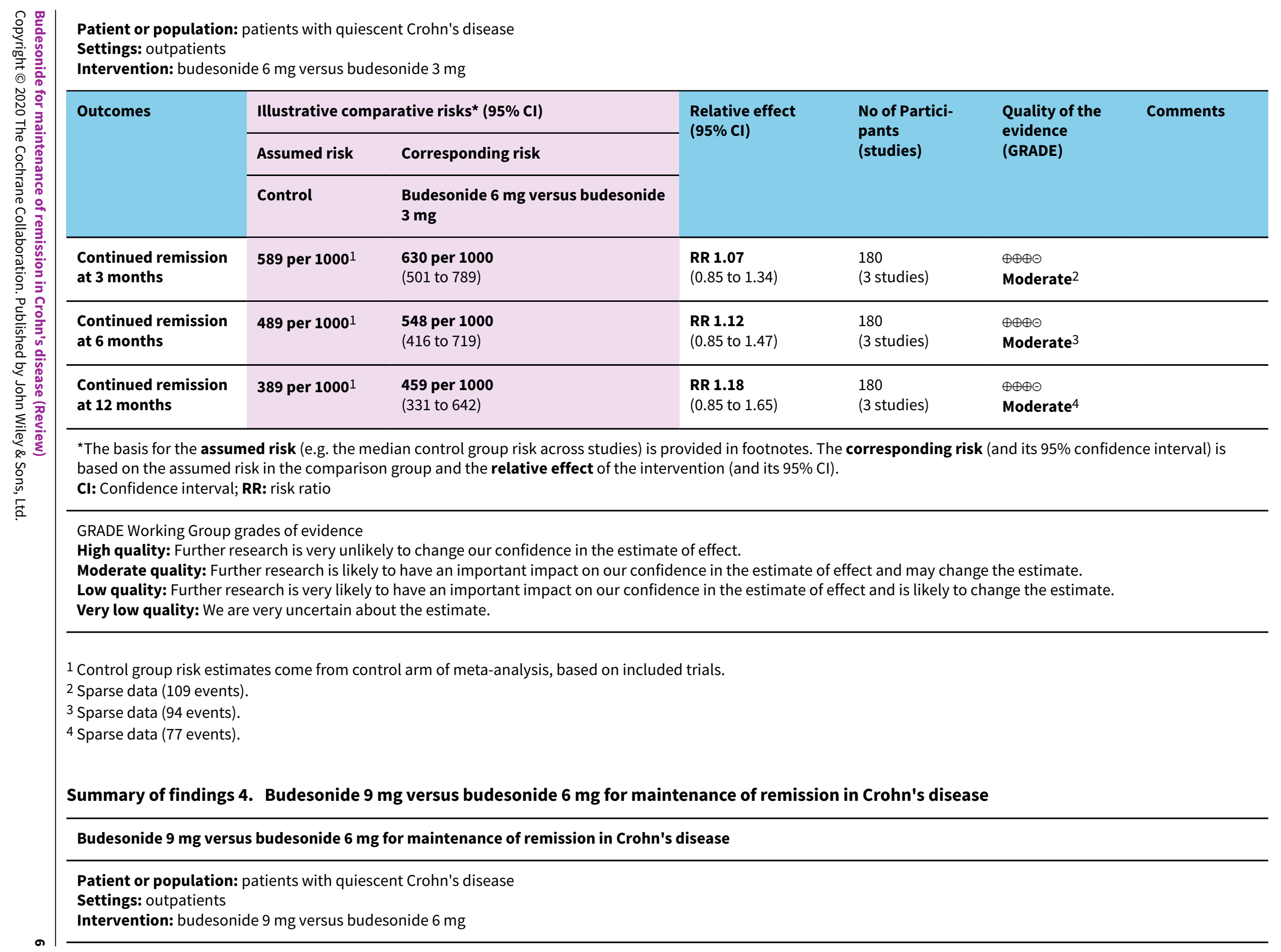




\begin{tabular}{|c|c|c|c|c|c|c|c|}
\hline \multirow{3}{*}{\multicolumn{2}{|c|}{ 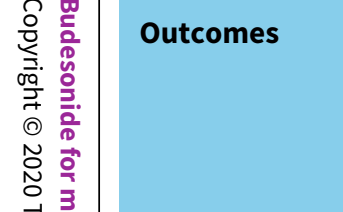 }} & \multicolumn{2}{|c|}{ Illustrative comparative risks* $(95 \% \mathrm{Cl})$} & \multirow{3}{*}{$\begin{array}{l}\text { Relative effect } \\
(95 \% \mathrm{Cl})\end{array}$} & \multirow{3}{*}{$\begin{array}{l}\text { No of Partici- } \\
\text { pants } \\
\text { (studies) }\end{array}$} & \multirow{3}{*}{$\begin{array}{l}\text { Quality of the evi- } \\
\text { dence } \\
\text { (GRADE) }\end{array}$} & \multirow[t]{3}{*}{ Comments } \\
\hline & & Assumed risk & Corresponding risk & & & & \\
\hline & & Control & Budesonide $9 \mathrm{mg}$ versus budesonide $6 \mathrm{mg}$ & & & & \\
\hline 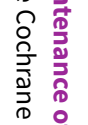 & $\begin{array}{l}\text { Continued re- } \\
\text { mission at } 12 \\
\text { months }\end{array}$ & 763 per $1000^{1}$ & $\begin{array}{l}\mathbf{8 1 6} \text { per } \mathbf{1 0 0 0} \\
(694 \text { to } 961)\end{array}$ & $\begin{array}{l}\text { RR } 1.07 \\
(0.91 \text { to } 1.26)\end{array}$ & $\begin{array}{l}157 \\
\text { (1 study) }\end{array}$ & $\begin{array}{l}\oplus \oplus \oplus \ominus \\
\text { Moderate }^{2}\end{array}$ & \\
\hline
\end{tabular}

*The basis for the assumed risk (e.g. the median control group risk across studies) is provided in footnotes. The corresponding risk (and its $95 \%$ confidence interval) is based on the assumed risk in the comparison group and the relative effect of the intervention (and its $95 \% \mathrm{Cl}$ ).

Cl: Confidence interval; RR: risk ratio

GRADE Working Group grades of evidence

High quality: Further research is very unlikely to change our confidence in the estimate of effect.

Moderate quality: Further research is likely to have an important impact on our confidence in the estimate of effect and may change the estimate.

Low quality: Further research is very likely to have an important impact on our confidence in the estimate of effect and is likely to change the estimate.

Very low quality: We are very uncertain about the estimate.

${ }^{1}$ Control group risk estimates come from control arm of meta-analysis, based on included trials.

2 Sparse data (124 events).

Summary of findings 5. Budesonide $\mathbf{9} \mathrm{mg}$ versus prednisolone $\mathbf{4 0} \mathrm{mg}$ for maintenance of remission in Crohn's disease

Budesonide $9 \mathrm{mg}$ versus prednisolone $40 \mathrm{mg}$ for maintenance of remission in Crohn's disease

Patient or population: patients with quiescent Crohn's disease

Settings: outpatients

Intervention: budesonide $9 \mathrm{mg}$ versus prednisolone $40 \mathrm{mg}$

\begin{tabular}{|c|c|c|c|c|c|c|}
\hline \multirow[t]{3}{*}{ Outcomes } & \multicolumn{2}{|c|}{ Illustrative comparative risks* $(95 \% \mathrm{CI})$} & \multirow{3}{*}{$\begin{array}{l}\text { Relative effect } \\
(95 \% \mathrm{CI})\end{array}$} & \multirow{3}{*}{$\begin{array}{l}\text { No of Partici- } \\
\text { pants } \\
\text { (studies) }\end{array}$} & \multirow{3}{*}{$\begin{array}{l}\text { Quality of the } \\
\text { evidence } \\
\text { (GRADE) }\end{array}$} & \multirow[t]{3}{*}{ Comments } \\
\hline & Assumed risk & Corresponding risk & & & & \\
\hline & Control & Budesonide $9 \mathrm{mg}$ versus prednisolone $40 \mathrm{mg}$ & & & & \\
\hline $\begin{array}{l}\text { Continued re- } \\
\text { mission at } 12 \\
\text { months }\end{array}$ & 636 per $1000^{1}$ & $\begin{array}{l}\mathbf{5 0 2} \text { per } \mathbf{1 0 0 0} \\
(350 \text { to } 719)\end{array}$ & $\begin{array}{l}\mathbf{R R} \mathbf{0 . 7 9} \\
\text { (0.55 to } 1.13 \text { ) }\end{array}$ & $\begin{array}{l}90 \\
\text { (1 study) }\end{array}$ & $\begin{array}{l}\oplus \oplus \ominus \ominus \\
\text { Low }^{2,3}\end{array}$ & \\
\hline
\end{tabular}


*The basis for the assumed risk (e.g. the median control group risk across studies) is provided in footnotes. The corresponding risk (and its $95 \%$ confidence interval) is based on the assumed risk in the comparison group and the relative effect of the intervention (and its $95 \% \mathrm{Cl}$ ).

Cl: Confidence interval; RR: risk ratio

GRADE Working Group grades of evidence

High quality: Further research is very unlikely to change our confidence in the estimate of effect.

Moderate quality: Further research is likely to have an important impact on our confidence in the estimate of effect and may change the estimate.

Low quality: Further research is very likely to have an important impact on our confidence in the estimate of effect and is likely to change the estimate.

Very low quality: We are very uncertain about the estimate.

1 Control group risk estimates come from control arm of meta-analysis, based on included trials.

2 Sparse data (51 events).

3 High risk of bias due to lack of blinding.

\section{Summary of findings 6 . Budesonide $6 \mathrm{mg}$ versus mesalamine $\mathbf{3} \mathrm{g}$ for maintenance of remission in Crohn's disease}

\section{Budesonide $6 \mathrm{mg}$ versus mesalamine $3 \mathrm{~g}$ for maintenance of remission in Crohn's disease}

Patient or population: patients with quiescent Crohn's disease

Settings: outpatients

Intervention: budesonide $9 \mathrm{mg}$ versus mesalamine $3 \mathrm{~g}$

\begin{tabular}{|c|c|c|c|c|c|c|}
\hline \multirow[t]{3}{*}{ Outcomes } & \multicolumn{2}{|c|}{ Illustrative comparative risks* $(95 \% \mathrm{CI})$} & \multirow{3}{*}{$\begin{array}{l}\text { Relative effect } \\
(95 \% \mathrm{CI})\end{array}$} & \multirow{3}{*}{$\begin{array}{l}\text { No of Partici- } \\
\text { pants } \\
\text { (studies) }\end{array}$} & \multirow{3}{*}{$\begin{array}{l}\text { Quality of the evi- } \\
\text { dence } \\
\text { (GRADE) }\end{array}$} & \multirow[t]{3}{*}{ Comments } \\
\hline & Assumed risk & Corresponding risk & & & & \\
\hline & Control & Budesonide $6 \mathrm{mg}$ versus mesalamine $\mathbf{3} \mathrm{g}$ & & & & \\
\hline $\begin{array}{l}\text { Continued re- } \\
\text { mission at } 12 \\
\text { months }\end{array}$ & 179 per $1000^{1}$ & $\begin{array}{l}\mathbf{4 4 9} \text { per } \mathbf{1 0 0 0} \\
\text { (184 to } 1096)\end{array}$ & $\begin{array}{l}\text { RR } 2.51 \\
\text { (1.03 to } 6.12 \text { ) }\end{array}$ & $\begin{array}{l}57 \\
\text { (1 study) }\end{array}$ & $\begin{array}{l}\oplus \ominus \ominus \ominus \\
\text { Very low } 2,3\end{array}$ & \\
\hline
\end{tabular}

${ }^{*}$ The basis for the assumed risk (e.g. the median control group risk across studies) is provided in footnotes. The corresponding risk (and its $95 \%$ confidence interval) is based on the assumed risk in the comparison group and the relative effect of the intervention (and its $95 \% \mathrm{Cl}$ ).

CI: Confidence interval; RR: risk ratio

GRADE Working Group grades of evidence

High quality: Further research is very unlikely to change our confidence in the estimate of effect.

Moderate quality: Further research is likely to have an important impact on our confidence in the estimate of effect and may change the estimate.

Low quality: Further research is very likely to have an important impact on our confidence in the estimate of effect and is likely to change the estimate.

Very low quality: We are very uncertain about the estimate. 
1 Control group risk estimates come from control arm of meta-analysis, based on included trials.
2 Very sparse data (18 events).

3 High risk of bias due to lack of blinding.

\section{Summary of findings 7. Budesonide 6-9 $\mathrm{mg}$ versus azathioprine 2-2.5 $\mathrm{mg} / \mathrm{kg}$ for maintenance of remission in Crohn's disease}

Budesonide 6-9 $\mathrm{mg}$ versus azathioprine 2-2.5 $\mathrm{mg} / \mathrm{kg}$ for maintenance of remission in Crohn's disease

Patient or population: patients with quiescent Crohn's disease

Settings: outpatients

Intervention: budesonide 6-9 mg versus azathioprine $2-2.5 \mathrm{mg} / \mathrm{kg}$

\begin{tabular}{|c|c|c|c|c|c|c|}
\hline \multirow[t]{3}{*}{ Outcomes } & \multicolumn{2}{|c|}{ Illustrative comparative risks* $(95 \% \mathrm{CI})$} & \multirow{3}{*}{$\begin{array}{l}\text { Relative effect } \\
(95 \% \mathrm{CI})\end{array}$} & \multirow{3}{*}{$\begin{array}{l}\text { No of Partici- } \\
\text { pants } \\
\text { (studies) }\end{array}$} & \multirow{3}{*}{$\begin{array}{l}\text { Quality of the evi- } \\
\text { dence } \\
\text { (GRADE) }\end{array}$} & \multirow[t]{3}{*}{ Comments } \\
\hline & Assumed risk & Corresponding risk & & & & \\
\hline & Control & $\begin{array}{l}\text { Budesonide 6-9 } \mathrm{mg} \text { versus azathioprine } \\
2-2.5 \mathrm{mg} / \mathrm{kg}\end{array}$ & & & & \\
\hline $\begin{array}{l}\text { Continued re- } \\
\text { mission at } 12 \\
\text { months }\end{array}$ & 789 per $1000^{1}$ & $\begin{array}{l}639 \text { per } 1000 \\
(481 \text { to } 852)\end{array}$ & $\begin{array}{l}\text { RR 0.81 } \\
\text { (0.61 to } 1.08 \text { ) }\end{array}$ & $\begin{array}{l}77 \\
\text { (1 study) }\end{array}$ & $\begin{array}{l}\oplus \odot \Theta \odot \\
\text { Very low } 2,3\end{array}$ & \\
\hline
\end{tabular}

${ }^{*}$ The basis for the assumed risk (e.g. the median control group risk across studies) is provided in footnotes. The corresponding risk (and its $95 \%$ confidence interval) is based on the assumed risk in the comparison group and the relative effect of the intervention (and its $95 \% \mathrm{Cl}$ ).

Cl: Confidence interval; RR: risk ratio

GRADE Working Group grades of evidence

High quality: Further research is very unlikely to change our confidence in the estimate of effect.

Moderate quality: Further research is likely to have an important impact on our confidence in the estimate of effect and may change the estimate.

Low quality: Further research is very likely to have an important impact on our confidence in the estimate of effect and is likely to change the estimate.

Very low quality: We are very uncertain about the estimate.

1 Control group risk estimates come from control arm of meta-analysis, based on included trials.

2 Sparse data (55 events).

3 High risk of bias due to lack of single-blind design and lack of allocation concealment. 


\section{B A C K G R O U N D}

Crohn's disease (CD) is characterized by chronic transmural inflammation of the gastrointestinal tract (Bousvaros 2007), characterized by symptoms of abdominal pain, diarrhea, and fatigue. Disease activity ranges from chronic clinical activity to a series of relapses and remissions. CD is currently thought to be caused by a cascade of immunologic reactions triggered by environmental factors in a genetically predisposed host. Corticosteroids are a mainstay of treatment for acute flares of CD in adults (Baumgart 2007), and children (Hyams 2005). Corticosteroids down-regulate production of inflammatory cytokines such as interleukin (IL)-1, IL-6, and tumour necrosis factor (TNF)-alpha by inhibiting transcription of specific genes involved in their production (Hyams 2000). Corticosteroids also inhibit protein synthesis by affecting the stability of messenger RNA (Barnes 1993). The interaction between corticosteroid receptors and NF-kB results in down regulation of NF-kB and therefore a blunting of inflammatory response (Yang 2002). Unfortunately, systemic corticosteroids are associated with adverse effects such as moon facies, acne, infection (increased risk of abdominal and pelvic abscess in CD patients), ecchymoses, hypertension, diabetes mellitus, osteoporosis, cataracts, glaucoma, and growth failure in children (Baumgart 2007). Additionally, use of systemic corticosteroids has been independently associated with mortality in patients with IBD (Lewis 2008).

Budesonide is a glucocorticoid with anti-inflammatory effects and limited systemic bioavailability due to extensive (90\%) firstpass hepatic metabolism by cytochrome p-450 enzymes. These properties theoretically limit systemic adverse effects. Budesonide is commercially available in two forms: an oral controlled ileal release (CIR) preparation designed to deliver the drug to the distal small intestine (Entocort ${ }^{\circledR}$, Astra Zeneca, London, UK; Entocir ${ }^{\circledR}$, Sofar S.p.A, Trezzano Rosa, Italy; Budecol ${ }^{\circledR}$, AstraZeneca A\&D, Lund, Sweden) and a $\mathrm{pH}$-dependent release formulation (Budenofalk ${ }^{\circledR}$ or Budeson ${ }^{\circledR}$, Dr Falk Pharma, Freiburg, Germany). The controlledileal release medication is in the form of a gelatin capsule containing acid-stable microgranules composed of an inner sugar core surrounded by a layer of budesonide in ethylcellulose and an outer acrylic-based resin coating (Eudragit $\mathrm{L} 100-55$ ) that dissolves at a $\mathrm{pH}$ higher than 5.5. The $\mathrm{pH}$-dependent release formulation is available as a capsule containing 400 pellets of budesonide coated with Eudragit resistant to a pH of less than six (Fedorak 2005).

Budesonide has been shown to be effective with minimal adverse events when used to induce clinical remission in active $C D$ affecting the distal ileum and right colon (Seow 2008). However, previous meta-analyses conducted for the Cochrane Collaboration found that budesonide was not effective for maintaining clinical remission in patients with $C D$ and did not increase the risk of adverse events (Benchimol 2009). The goal of this systematic review and meta-analysis was to update the evidence with regard to the safety and efficacy of budesonide for maintenance of remission in $C D$ based on the results of all published clinical trials, including recently conducted studies. This systematic review is an update of previously published Cochrane reviews (Benchimol 2009; Simms 2001).

\section{O B JE C T IVES}

The primary objective was to assess the efficacy and safety of budesonide therapy for maintenance of remission in CD.

\section{METHODS}

\section{Criteria for considering studies for this review}

\section{Types of studies}

Randomized controlled trials (RCTs) published in any language, were included. Studies published in abstract form only were included if enough data were provided in print or from the study authors to assess the outcome.

\section{Types of participants}

Participants included patients of any age (adults or children) with $C D$ defined by conventional clinical, radiological and endoscopic criteria, which was categorized as being in remission, as defined by a Crohn's Disease Activity Index (CDAI) $\leq 150$ (Best 1976) or Pediatric Crohn's Disease Activity Index (PCDAl) $\leq 15$ (Hyams 1991), or a validated severity index indicating quiescent disease (e.g. HarveyBradshaw Index (Harvey 1980), Van Hees Index (van Hees 1980)).

\section{Types of interventions}

RCTs of oral budesonide therapy (CIR or pH-dependent release formulations) compared to placebo, active comparators or different doses of budesonide were considered for inclusion. Co-interventions were permitted provided they were balanced between treatment and control groups.

\section{Types of outcome measures}

The primary outcome measure was the number of patients maintaining remission following initiation of maintenance therapy. Where remission rates were not reported or available from study authors, remission rates were defined as the opposite proportion ( 1 - relapse rate, or $100 \%$ - relapse rate percentage).

Secondary outcomes included:

- change in mean CDAI;

- mean time to relapse;

- adverse events, including:

- treatment-related adverse events

- abnormal ACTH test);

- withdrawal due to adverse events; or

- withdrawal due to treatment failure; and,

- change in quality of life scores (as defined by scores on either the IBD Questionnaire (IBDQ) or the IMPACT questionnaire for pediatrics).

\section{Search methods for identification of studies}

The same comprehensive search used in previous versions of this review was updated for this review (Simms 2001; Benchimol 2009). A detailed outline of the search strategy is provided in Appendix 1. We searched the following databases from inception to June 2014: PubMed, MEDLINE, EMBASE and the Cochrane Central Register of Controlled Trials (June 2014). The Cochrane Inflammatroy Bowel Disease and Functional Bowel Disorders (IBD/FBD) Group Specialised Trials Register and conference proceedings from major gastroenterology meetings (e.g. American Gastroenterology Association, British Society of Gastroenterology, United European Gastroenterology Week, Digestive Disease Week) were searched manually from 2009 onwards. Ongoing and unpublished trials were identified using ClinicalTrials.gov. We searched the reference 
lists of trials and review articles to identify additional studies. Relevant pharmaceutical companies were also contacted for further information.

\section{Data collection and analysis}

\section{Selection of studies}

Abstracts of all articles identified using the above search strategy were screened for eligibility. Studies were included in the full-text review if they were potentially eligible for inclusion or if they were relevant review articles, for manual reference search. The retrieved full text articles were then independently reviewed by MEK and AR for eligibility.

\section{Data extraction and management}

Two authors (MEK and AR) independently completed a data extraction form for each eligible study. The following data were retrieved:

1. General information: title, journal, year, published or unpublished.

2. Study information: design (e.g. who was blinded), years of enrolment, crossover or not, methods used to ensure adequacy of randomization, allocation concealment and blinding, power calculation (a priori and post hoc).

3. Intervention: formulation and dose of budesonide, type of comparison group, co-intervention.

4. Eligibility: inclusion/exclusion criteria, total number screened and randomized.

5. Baseline characteristics (in each group): age, sex, race, disease severity (and how evaluated), concurrent medications used, disease location, prior surgery, time since last surgery, CDAI/ PCDAl, length of symptoms prior to randomization.

6. Follow-up: length of follow-up, assessment of compliance, withdrawals and loss to follow-up.

7. Outcome: Remission rates at 3, 6 and 12 months following initiation of treatment or placebo, mean CDAl scores at each time point, adverse event details, IBQ quality of life score, proportion with abnormal ACTH stimulation test.

\section{Assessment of methodological quality of included studies}

The Cochrane risk of bias tool was utilized to assess the quality of included studies (Higgins 2011). The assessment of study quality included the methods used for randomization and allocation concealment (both measures of selection bias); blinding (performance and detection biases); incomplete outcome data (attrition bias); and selective reporting of study outcomes (reporting bias). Each potential source of bias was scored as low risk of bias (high quality) or high risk of bias (low quality). If a criterion could not be evaluated, that characteristic was considered to have an unclear risk of bias. The quality of included studies was assessed independently by two reviewers (MEK and AR). Disagreeements were settled by consensus. Any study with at least one aspect of study quality determined to be at high risk of bias was excluded from the analysis in a sensitivity analysis.

The overall quality of evidence was assessed using the GRADE approach (Guyatt 2008; Schünemann 2011). The GRADE approach appraises the overall quality of a body of evidence based on the extent to which one can be confident that an estimate of effect reflects the item being assessed. Randomised trials start as high quality evidence, but may be downgraded due to: risk of bias (methodological quality), indirectness of evidence, unexplained heterogeneity, imprecision (sparse data) and publication bias. The overall quality of the evidence for each outcome was determined after considering each of these factors and graded as:

- High: further research is very unlikely to change confidence in the estimate of effect;

- Moderate: further research is likely to have an important impact on confidence in the estimate of effect and may change the estimate;

- Low: further research is very likely to have an important impact on confidence in the estimate of effect and is likely to change the estimate; and

- Very low: any estimate of effect is very uncertain.

\section{STATISTICAL ANALYSIS}

Data were analyzed using Review Manager (RevMan 5.3, Copenhagen: The Nordic Cochrane Centre, The Cochrane Collaboration, 2014).

\section{Measures of treatment effect}

For dichotomous outcomes we calculated the risk ratio and corresponding 95\% confidence interval $(95 \% \mathrm{Cl})$. When relapse rates were reported in the study, the proportion of patients in remission was defined as those who did not relapse and did not withdraw from the study (i.e., intention-to-treat analysis). We calculated the mean difference and corresponding $95 \% \mathrm{Cl}$ for continuous outcomes (e.g. change in CDAl and mean time to relapse). The analysis of studies using placebo or other control interventions was conducted separately.

\section{Meta-analysis}

Data from individual studies were pooled for meta-analysis if the interventions, patient groups and outcomes were sufficiently similar (determined by consensus). Random-effects models were used to combine data to allow for expected clinical and statistical heterogeneity across studies (DerSimonian 1986).

\section{Subgroup analysis}

The following a priori subgroup analyses were attempted, governed by the number of identified studies: dose of budesonide used (in milligrams (mg)), pediatric versus adult patients (not done due to absence of pediatric studies), different formulations of budesonide (e.g., CIR versus $\mathrm{pH}$-modified form), disease location (not done due to the majority of studies including patients with disease limited to the ileum or ileocecal regions), and the method used to induce remission (e.g., medical versus surgical treatment). Subgroups were chosen based on the possibility that differing doses or formulations and disease location may impact on success of treatment success.

\section{Assessment of Heterogeneity}

Heterogeneity was assessed by calculating the 12 measure, interpreted as low heterogeneity (25\%), moderate heterogeneity (50\%) and high heterogeneity (75\%) (Higgins 2003). Cochran's Chi2 test for homogeneity ( $\mathrm{Q}$ test) was also calculated with $\mathrm{P}<0.10$ being considered statistically significant.

\section{Sensitivity analysis}

In order to assess the robustness of the eligibility criteria, a sensitivity analysis was planned to exclude poor quality studies (as defined by "high risk" in at least one quality criterion), studies 
published in abstract form only, studies not reporting methods to assess compliance and small studies ( $<50$ patients).

\section{RES U L T S}

\section{Description of studies}

The literature search conducted on 12 June 2014 identified 2732 records. After duplicates were removed, a total of 2167 studies remained for review of titles and abstracts. Two authors (MEK and AR) independently reviewed the titles and abstracts of these trials and 20 studies were selected for full text review (see Figure 1). Eight studies were excluded (See:Characteristics of excluded studies). Twelve studies ( $n=1273$ patients) met the pre-defined inclusion criteria and were included in the review (See Characteristics of included studies). These studies evaluated budesonide for maintenance of remission in patients with quiescent CD. Nine studies used CIR budesonide (Cortot 2001; Ferguson 1998; Greenberg 1996; Hanauer 2005; Hellers 1999; Lofberg 1996; Mantzaris 2003; Mantzaris 2009; Schoon 2005) and three studies used a pH-dependent formulation (de Jong 2007; Ewe 1999; Gross 1998). The included studies are described below in chronological order of publication. 
Figure 1. Study flow diagram.

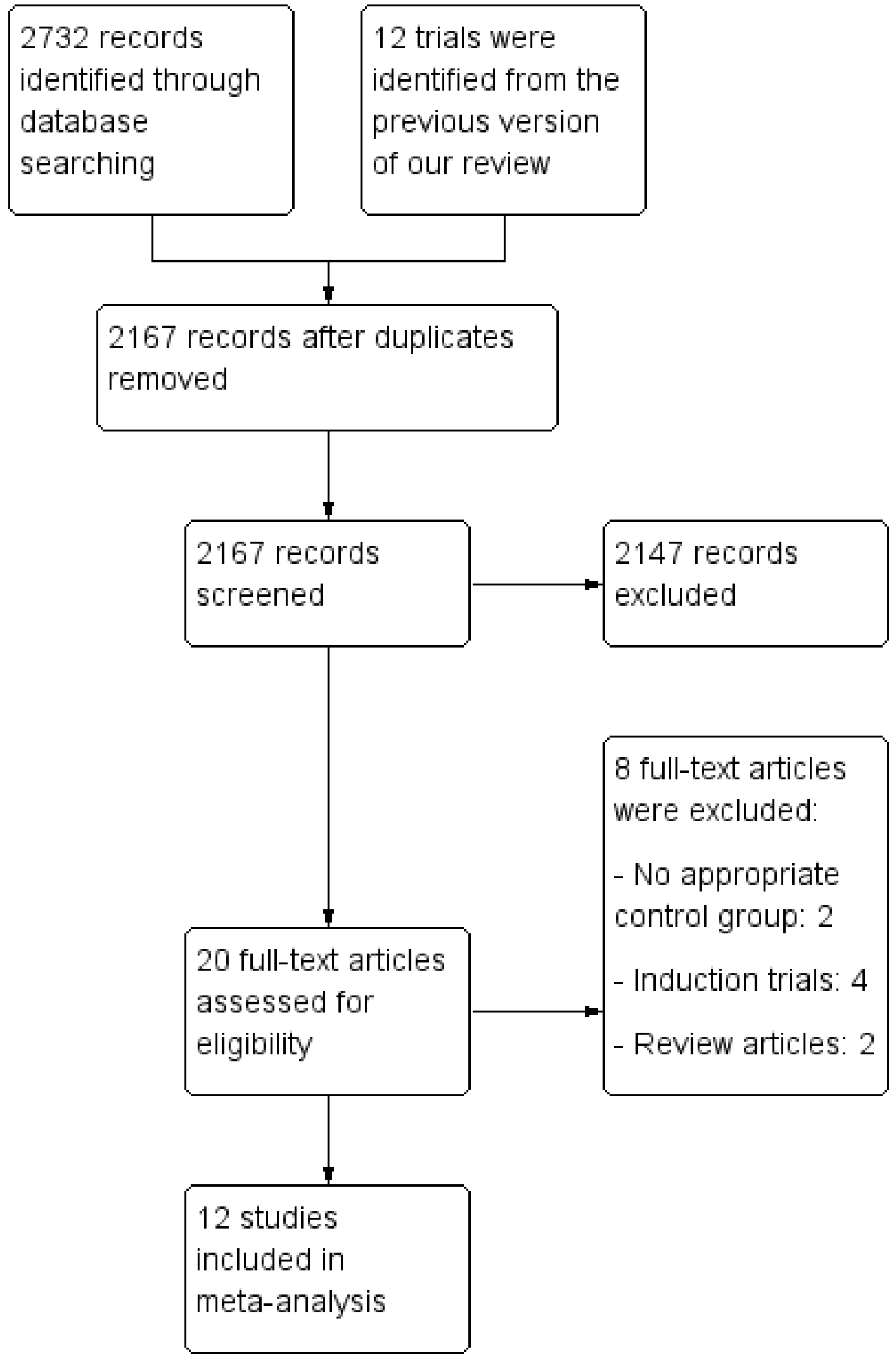


This RCT was conducted at 32 centres in Canada from January 1992 to February $1994(\mathrm{~N}=105)$. It was designed as a parallel arm trial with three arms, CIR budesonide $6 \mathrm{mg}$ compared with 3 $\mathrm{mg}$ and placebo. Induction of remission was accomplished with budesonide $15 \mathrm{mg}, 9 \mathrm{mg}, 3 \mathrm{mg}$ or placebo as part of a previously published clinical trial. Twenty-seven per cent of patients enrolled in this study had received $9 \mathrm{mg}$ of budesonide on an open label basis following withdrawal from the acute trial due to treatment failure. Patients with quiescent disease $(C D A I \leq 150)$ restricted to the ileum and proximal colon were randomized to receive either budesonide $6 \mathrm{mg}$ once daily $(\mathrm{n}=36)$, budesonide $3 \mathrm{mg}$ once daily $(n=33)$ or placebo $(n=36)$ and followed for 52 weeks. Outcomes assessed included remission rates (obtained from study sponsor), relapse rates, time to relapse (obtained from study sponsor), quality of life scores using IBDQ, change in serum C-reactive protein and ACTH stimulation test.

\section{Lofberg 1996}

This RCT was performed in multiple Swedish centres and five other European countries and compared CIR budesonide $6 \mathrm{mg}$ with $3 \mathrm{mg}$ and placebo $(\mathrm{N}=90)$. Induction of remission was accomplished with a ten-week course of either budesonide or prednisolone as part of a clinical trial. Patients with quiescent disease (CDAI $\leq 150)$ restricted to the ileum or ileocecal region were randomized to receive budesonide $6 \mathrm{mg}$ once daily $(n=32)$, budesonide $3 \mathrm{mg}$ once daily $(n=31)$, or placebo $(n=27)$ for 12 months. Outcomes assessed included remission rates (obtained from study sponsor), relapse rates, time to relapse, adverse events and ACTH stimulation test.

\section{Ferguson 1998}

With 20 centres involved, this study was performed in seven European countries and Australia $(N=75)$. Remission was induced using a 12-week course of budesonide in a clinical trial. Patients were included if their disease was in remission (CDAI $\leq 150)$ and limited to the ileum, ileocecal region, or ascending colon. Seventyfive patients were randomized to receive either CIR budesonide 3 mg twice daily $(n=22)$, CIR budesonide $3 \mathrm{mg}$ once daily $(n=26)$, or placebo $(n=27)$ for 12 months. Outcomes assessed included remission rates (obtained from study sponsor), disease relapse rates, time to relapse, adverse events, baseline plasma cortisol and ACTH stimulation test.

\section{Gross 1998}

This multicenter German trial evaluated the efficacy of a $\mathrm{pH}$ dependent release formulation of budesonide designed to release at a $\mathrm{pH}$ greater than $6.4(\mathrm{~N}=179)$. Patients were screened for this RCT when they had active disease (CDAI > 200) and placed on the identical regimen of systemic corticosteroids used in the European Cooperative Crohn's Disease Study (ECCDS, Malchow 1984), consisting of oral 6-methylprednisolone at a dose of $48 \mathrm{mg} /$ day for one week and then reduced to $32 \mathrm{mg}, 24 \mathrm{mg}, 20 \mathrm{mg}, 16 \mathrm{mg}$ and $12 \mathrm{mg}$ on a weekly basis. In order to enter the maintenance study, patients were required to be in remission (CDAI $\leq 150)$ and to have required only 5 to $10 \mathrm{mg}$ of prednisolone for the preceding eight weeks. Patients were randomized to receive budesonide 1 mg three times daily $(n=84)$, or placebo $(n=95)$ for 12 months. Outcomes included relapse rates, time to relapse and adverse events.

\section{Ewe 1999}

This multicenter German study involving three universitybased hospitals assessed a $\mathrm{pH}$-dependent release formulation of budesonide, comparing $3 \mathrm{mg} /$ day to placebo. Patients were enrolled following remission induced by surgical resection of ileal, ileocolonic or colonic disease. The location of the anastomotic site was required to be accessible by colonoscope, and no disease could be grossly visible at the resection margins. A total of 83 patients were randomized. The most common indications for surgery included: ileus, chronic obstruction, stenosis or stricture $(n=71)$, fistula, abscess or abdominal mass $(n=41)$, and failure of medical management $(n=25)$. Patients were randomized to receive either budesonide $1 \mathrm{mg}$ three times daily $(n=43)$, or placebo $(\mathrm{n}=40)$ for 12 months. The primary outcome was recurrence of CD based on endoscopic findings (Rutgeerts 1990). In cases where colonoscopy was refused, recurrence was defined as an increase in CDAl from 60 up to 200 from the first follow-up or a CDAI > 200 and signs or symptoms characteristic of active Crohn's disease. Secondary outcomes included histology scores, change in CDAI, global judgement of well-being and time to recurrence.

\section{Hellers 1999}

Patients who underwent ileocolonic resection in 13 European centres were included in this study $(\mathrm{N}=130)$. Screening and consent were obtained prior to surgery and complete resection of ileocolonic disease was verified with intraoperative endoscopy or eversion of the neoterminal ileum with direct visualization of the margins. Biopsy specimens were also obtained to confirm absence of disease. The reason for surgical resection was not detailed in the publication. Patients were randomized to $\mathrm{CIR}$ budesonide $6 \mathrm{mg}$ daily $(\mathrm{n}=63)$, or placebo $(\mathrm{n}=67)$ for 52 weeks. Outcomes included remission rates (obtained from study sponsor), endoscopic recurrence (Rutgeerts 1990), CDAl score, adverse events and ACTH stimulation test.

\section{Cortot 2001}

This study examined the utility of CIR budesonide to maintain clinical remission in corticosteroid-dependent $\mathrm{CD}$ patients $(\mathrm{N}$ $=120$ ). It was performed in 24 centres across Europe, Israel, and South Africa. All enrolled patients received prednisolone or prednisone 10 to $30 \mathrm{mg} /$ day for at least six months prior to study entry with at least two attempts to taper the dose with resulting relapsed disease. Patients had inactive CD at entry (CDAI $\leq 200$ ). Concomitant immune suppression with azathioprine was initially an exclusion criteria, however this was revised midway during the study to facilitate enrolment. Patients were permitted to enrol if they received azathioprine for a minimum of six months or 5aminosalicylates for a minimum of one month prior to entry to ensure an adequate trial of these medications and allow for further steroid weaning. Patients were randomized to CIR budesonide $6 \mathrm{mg}$ once daily ( $n=60)$, or placebo $(n=60)$ for 16 to 22 weeks. Length of treatment depended on corticosteroid dose at entry. Prednisolone was tapered by $5 \mathrm{mg}$ per week until $20 \mathrm{mg}$ and thereafter by $2.5 \mathrm{mg}$ per week until the dose was zero. Patients were assessed every four weeks while on prednisolone and then at six and 12 weeks following discontinuation. The primary outcome was rate of relapse (defined as CDAI > 200 with an increase of at least 60 points from baseline). Secondary outcomes included changes in CDAl, time to relapse, quality of life (IBDQ), and adverse events.

\section{Hanauer 2005}

This American RCT compared CIR budesonide to placebo in patients in clinical remission $(\mathrm{CDAl} \leq 150)$ with disease restricted to the distal ileum or proximal colon $(\mathrm{N}=110)$. Induction of remission was achieved using an eight week course of budesonide $9 \mathrm{mg} /$ day as part of a clinical trial. Patients were randomized to CIR 
budesonide $6 \mathrm{mg}$ once daily $(n=55)$, or placebo $(n=55)$ for 52 weeks. Outcomes included remission rates (obtained from study sponsor), disease relapse, time to relapse, adverse events and ACTH stimulation test.

\section{STUDIES COMPARING BUDESONIDE TO 5-AMINOSALICYLATES}

\section{Mantzaris 2003}

This investigator-blinded study was conducted in a single-centre in Greece $(N=57)$. Patients in clinical remission (CDAl $\leq 150$ ) were included if they were steroid-dependent, defined as having received at least two courses of oral or intravenous corticosteroids in the 12 months prior to enrolment with a relapse of disease prior to discontinuation. Patients' disease was localised to the ileum, ileocolonic region or proximal colon. Remission was achieved using systemic corticosteroids with a minimum dose of $1 \mathrm{mg} / \mathrm{kg}$ for at least 4 months prior to study entry followed by a tapering of 5 $\mathrm{mg} /$ week to the lowest dose that effectively maintained remission. Patients were randomized to CIR budesonide $6 \mathrm{mg}$ daily $(\mathrm{n}=29)$ or $\mathrm{pH}$-dependent release mesalamine (Salofalk) 1 gram three times daily ( 3 grams/day) for 1 year $(n=28)$. Outcomes included disease relapse, time to relapse, quality of life assessment using IBDQ, and adverse events.

\section{STUDIES COMPARING BUDESONIDE TO TRADITIONAL CORTICOSTEROIDS}

Schoon 2005

This RCT was performed in 34 centres in 8 European countries and Israel $(\mathrm{N}=90)$ and evaluated the efficacy of CIR budesonide at maintaining remission compared with low-dose systemic corticosteroids (prednisolone). Two categories of patients were included in this study: corticosteroid-free patients with mild to severe active $C D(C D A I \geq 150)$ who had not received steroids during the 6 months prior to enrolment; and corticosteroid-dependent patients with disease in remission $(C D A I \leq 200)$ while receiving traditional corticosteroids. Only the latter group was evaluated for this review. It is noteworthy that the full journal article referenced here evaluates the bone mineral density of patients in the two intervention groups (Schoon 2005). Efficacy outcomes for the steroid-dependent group in clinical remission are detailed in a published abstract (Stockbrugger 2003). Additional information was obtained from the study authors. Subjects were randomized to continued prednisolone therapy ( 7 to $20 \mathrm{mg} /$ day) as per a predefined regimen $(n=44)$ or CIR budesonide $9 \mathrm{mg} /$ day for 24 months with tapering of corticosteroid dose by $5 \mathrm{mg} /$ week $(\mathrm{n}=$ 46). Patients and physicians were not blinded to the intervention. Outcomes included continued remission rates, quality of life assessment using IBDQ, adverse events, ACTH stimulation test and bone mineral density using dual energy $x$-ray absorptiometry (DXA).

\section{STUDIES COMPARING BUDESONIDE TO AZATHIOPRINE}

This study was conducted in Greece between January 1998 and November $2001(\mathrm{~N}=77)$. Patients receiving 6 to $9 \mathrm{mg}$ of $\mathrm{CIR}$ budesonide $(n=39)$ were compared to patients receiving 2.0 to $2.5 \mathrm{mg}$ azathioprine $(\mathrm{n}=38)$ for one year with the option of entering a six month study extension. Dose of budesonide was based on the dose of prednisolone required to maintain remission $(\mathrm{CDAl} \leq 150)$ prior to beginning the study. Patients were steroiddependent at study onset, as defined by at least one flare in the last 6 to 12 months, followed by disease recurrence in response to tapering or withdrawal of steroids. Of note, patients were not aware that the study was a randomized controlled trial (separate consent forms were used for each trial arm) and were therefore not blinded to study treatment. Outcome measures included mucosal improvement based on the Crohn's Disease Endoscopic Index of Severity (CDEIS; Mary 1989); histologic improvement (D'Haens Score; D'Haens 1998); rates of continued clinical remission (no definition of remission is provided); withdrawals due to disease worsening and adverse events; time to treatment discontinuation; and laboratory parameters (C-reactive protein and erythrocyte sedimentation rate).

\section{STUDIES COMPARING TWO DOSES OF BUDESONIDE}

\section{de Jong 2007}

Conducted in 32 centres in Germany and the Netherlands, this RCT compared two doses of $\mathrm{pH}$-modified release budesonide $(\mathrm{N}=157)$. Patients were included if their disease was in remission for at least 3 months (defined by a CDAI < 150), and was confined to the ileum or colon, except rectal and perianal involvement. All methods of induction of remission were permitted with the exception of small bowel resection $>80 \mathrm{~cm}$ within 6 months of enrolment. Patients were randomized to budesonide three capsules of $3 \mathrm{mg}$ once daily (total $9 \mathrm{mg} /$ day; $\mathrm{n}=81$ ) or budesonide two capsules of $3 \mathrm{mg}$ plus one placebo capsule once daily (total $6 \mathrm{mg} /$ day; $\mathrm{n}=76$ ). Outcome measures included relapse of disease, time to relapse and adverse events.

\section{Risk of bias in included studies}

The results of the risk of bias analysis are summarized in Figure 2. Three studies were identified as being at a high risk of bias due to inadequate blinding (Mantzaris 2003; Mantzaris 2009; Schoon 2005). Trial participants were not blinded in two trials, increasing the risk of performance bias (Mantzaris 2003; Mantzaris 2009); the outcome assessors were not blinded in the third (Schoon 2005), increasing the risk of detection bias. Each of these three studies compared budesonide to a different comparator (Mantzaris 2003: mesalamine; Mantzaris 2009: azathioprine; Schoon 2005: prednisolone). The study comparing budesonide with azathioprine was also at high risk of selection bias due to a failure to adequately conceal allocation (Mantzaris 2009). Since no other studies made these comparisons, a sensitivity analysis excluding studies at high risk of bias could not be performed. 
Figure 2. Risk of bias summary: review authors' judgements about each risk of bias item for each included study.

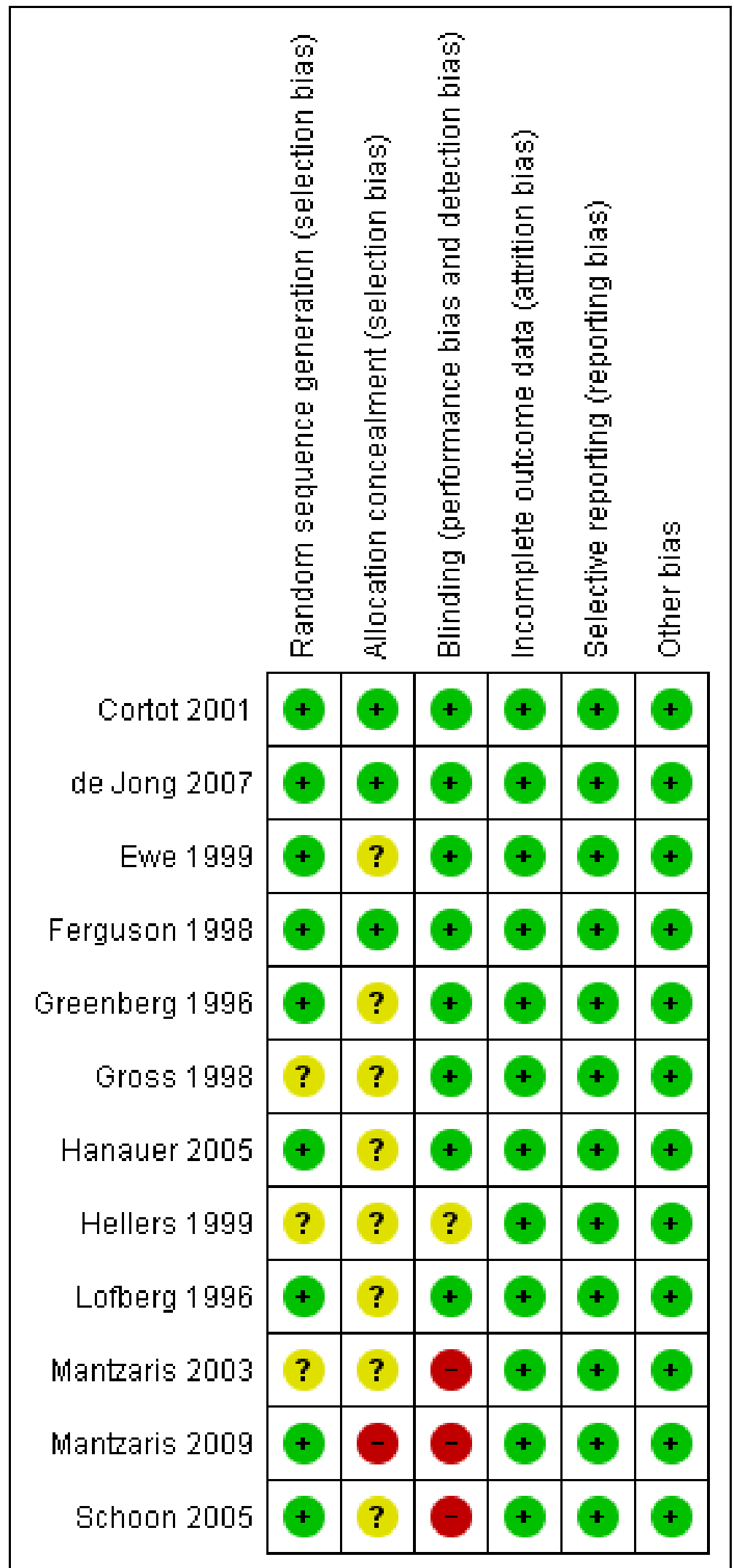




\section{Effects of interventions}

See: Summary of findings for the main comparison Budesonide $6 \mathrm{mg}$ versus placebo for maintenance of remission in Crohn's disease; Summary of findings 2 Budesonide $3 \mathrm{mg}$ versus placebo for maintenance of remission in Crohn's disease; Summary of findings 3 Budesonide $6 \mathrm{mg}$ versus budesonide $3 \mathrm{mg}$ for maintenance of remission in Crohn's disease; Summary of findings 4 Budesonide $9 \mathrm{mg}$ versus budesonide $6 \mathrm{mg}$ for maintenance of remission in Crohn's disease; Summary of findings 5 Budesonide $9 \mathrm{mg}$ versus prednisolone $40 \mathrm{mg}$ for maintenance of remission in Crohn's disease; Summary of findings 6 Budesonide $6 \mathrm{mg}$ versus mesalamine $3 \mathrm{~g}$ for maintenance of remission in Crohn's disease; Summary of findings 7 Budesonide 6-9 mg versus azathioprine 2-2.5 mg/kg for maintenance of remission in Crohn's disease

Summary of comparisons:

\section{A) MEASURES OF EFFICACY}

- Outcome 01: Maintenance of clinical remission

- Outcome 02: Change in CDAl from baseline values

- Outcome 03: Mean time to relapse of disease

- Outcome 04: Study withdrawals due to treatment failure

\section{B) MEASURES OF SAFETY AND ADVERSE EVENTS}

- Outcome 05: Proportion of patients with treatment-related adverse events at 12 months

- Outcome 06: Study withdrawals due to adverse events

- Outcome 07: Proportion of patients with abnormal ACTH stimulation test

\section{C) OTHER OUTCOMES}

- Quality of life (IBDQ)

\section{A. MEASURES OF EFFICACY}

\section{1) Maintenance of clinical remission (CDAI $\leq 150$ unless otherwise specified)}

\section{A) Budesonide $6 \mathrm{mg}$ versus placebo (Analysis 1.1)}

All studies included in this comparison used CIR budesonide compared with placebo. Cortot 2001 was the only study that compared budesonide $6 \mathrm{mg}$ to placebo among steroid-dependent patients and was the only study to demonstrate a statistically significant benefit of budesonide for maintenance of remission at three months follow-up (RR $1.90,95 \% \mathrm{Cl} 1.29$ to 2.81). None of the pooled analyses showed any statistically significant differences in continued remission rates between budesonide $6 \mathrm{mg}$ and placebo indicating that budesonide $6 \mathrm{mg}$ per day is not effective for maintenance of clinical remission in $C D$ in the long term. At three months $64 \%$ of budesonide $6 \mathrm{mg}$ patients remained in remission compared to $52 \%$ of placebo patients. The pooled risk ratio of continued remission using budesonide was $1.25(95 \% \mathrm{Cl} 1.00$ to 1.58 ; 6 studies, 540 patients) at 3 months. A GRADE analysis indicated that the overall quality of the evidence for this outcome (maintenance of clinical remission at 3 months) was low due to moderate heterogeneity $(12=56 \%)$ and sparse data ( 315 events, see Summary of findings for the main comparison). At six months $61 \%$ of budesonide $6 \mathrm{mg}$ patients remained in remission compared to
$52 \%$ of placebo patients (RR 1.15, 95\% Cl 0.95 to 1.39 ; 5 studies, 420 patients). A GRADE analysis indicated that the overall quality of the evidence for this outcome (maintenance of clinical remission at 6 months) was moderate due to sparse data (238 events, see Summary of findings for the main comparison). At 12 months 55\% of budesonide $6 \mathrm{mg}$ patients remained in remission compared to $48 \%$ of placebo patients (RR $1.13,95 \% \mathrm{Cl} 0.94$ to 1.35 ; 5 studies, 420 patients). A GRADE analysis indicated that the overall quality of the evidence for this outcome (maintenance of clinical remission at 6 months) was moderate due to sparse data (215 events, see Summary of findings for the main comparison). There was significant heterogeneity in remission rates at 3 months ( $12=56 \%$; $P$ $=0.04)$, but not at 6 months $(P=0.29 ; 12=19 \%)$ or 12 months $(P=$ $\left.0.56 ; I^{2}=0 \%\right)$. Of note, Cortot 2001 only reported 3-month data and its exclusion likely contributed to the lack of heterogeneity at 6 and 12 months and the lack of statistical significance at these later time points.

Similar results were observed when trials consisting of patients with budesonide-induced remission were included (RR 1.23, 95\% $\mathrm{Cl} 1.00$ to $1.52 ; 4$ studies, 290 patients). Removing trials of surgically-induced and steroid-dependent patients removed all heterogeneity across studies $(P=0.75 ; 12=0 \%)$. Further subgroup analyses including all patients with medically-induced remission (excluding patients who were induced surgically (Hellers 1999)) were performed for the 3 month and 12 month follow-ups. When excluding trials that induced remission surgically, budesonide was significantly better than placebo at maintaining remission at three months (RR $1.36,95 \% \mathrm{Cl} 1.11$ to 1.68 ; 5 studies, 410 patients) but there was no statistically significant difference at 12 months (RR $1.29,95 \% \mathrm{Cl} 1.00$ to $1.67 ; 4$ studies, 290 patients). There was no significant heterogeneity after excluding trials that induced remission surgically at either 3 months $\left(P=0.28 ; 1^{2}=21 \%\right)$ or 12 months $\left(P=0.28 ; 1^{2}=0 \%\right)$.

B) Budesonide $3 \mathrm{mg}$ versus placebo (Analysis 2.1)

Remission rates were defined by $\mathrm{CDAI} \leq 150$ for the $\mathrm{CIR}$ budesonide studies and as absence of disease relapse for the studies using $\mathrm{pH}$ modified release budesonide. Budesonide was better than placebo for maintaining remission when subjects were assessed at three months. Fifty-seven per cent of budesonide patients maintained remission at three months compared to $44 \%$ of placebo patients (RR 1.29, 95\% Cl 1.01 to 1.63; 4 studies, 263 patients). A GRADE analysis indicated that the overall quality of the evidence for this outcome (maintenance of clinical remission at 3 months) was moderate due to sparse data (133 events, see Summary of findings 2). There were no statistically significant differences in maintenance of remission at 6 months or 12 months. At 6 months, $49 \%$ of budesonide patients maintained remission compared to $44 \%$ of placebo patients (RR $1.12,95 \% \mathrm{Cl} 0.83$ to $1.51 ; 3$ studies, 180 patients). A GRADE analysis indicated that the overall quality of the evidence for this outcome (maintenance of clinical remission at 6 months) was moderate due to sparse data (84 events, see Summary of findings 2). At 12 months, $42 \%$ of budesonide patients maintained remission compared to $40 \%$ of placebo patients (RR $1.08,95 \% \mathrm{Cl} 0.87$ to $1.34 ; 5$ studies, 442 patients). A GRADE analysis indicated that the overall quality of the evidence for this outcome (maintenance of clinical remission at 12 months) was moderate due to sparse data (182 events, see Summary of findings 2). There was no significant heterogeneity across trials at any time point ( 3 months: $\mathrm{P}=0.87, \mathrm{I}^{2}=0 \% ; 6$ months: $\mathrm{P}=0.80, \mathrm{I}^{2}=0 \% ; 12$ months: 
$P=0.80,12=0 \%)$. Subgroup analyses were conducted to determine the efficacy of each budesonide formulation relative to placebo. Neither the $\mathrm{pH}$-modified formulation (RR $1.13,95 \% \mathrm{Cl} 0.84$ to 1.51 ; 2 studies, 262 patients) nor the CIR formulation (RR $1.00,95 \% \mathrm{Cl}$ 0.70 to 1.42 ; 3 studies, 180 patients) were effective for maintaining remission at 12 months of follow-up. There was no significant heterogeneity for either the $\mathrm{pH}$-modified formulation $\left(\mathrm{P}=0.28 ; \mathrm{I}^{2}\right.$ $=14 \%$ ) or the $\mathrm{CIR}$ formulation $\left(\mathrm{P}=0.64 ; \mathrm{I}^{2}=0.0 \%\right)$. A subgroup analysis including medically-induced patients was performed for the 3 month and 12 month follow-ups. There was no statistically significant difference between budesonide and placebo at either 3 months (RR $1.22,95 \% \mathrm{Cl} 0.93$ to 1.60; 3 studies, 180 patients) or 12 months (RR $0.98,95 \% \mathrm{Cl} 0.75$ to $1.28 ; 4$ studies, 359 patients). There was no significant heterogeneity at either 3 months $\left(P=0.94 ; 1^{2}=\right.$ $0 \%)$ or 12 months ( $P=0.82 ; 1^{2}=0 \%$, .

C) Budesonide $6 \mathrm{mg}$ versus budesonide $3 \mathrm{mg}$ (Analysis 4.1)

Remission rates in patients receiving $6 \mathrm{mg}$ budesonide were not significantly different from those receiving $3 \mathrm{mg}$ at 3 months, 6 months or 12 months. Fifty-six per cent of budesonide $6 \mathrm{mg}$ patients maintained remission at 3 months compared to $59 \%$ of patients in the budesonide $3 \mathrm{mg}$ group (RR 1.07; 95\% Cl 0.85 to $1.34 ; 3$ studies, 180 patients). At 6 months $56 \%$ of patients in the budesonide $6 \mathrm{mg}$ group maintained remission compared to $49 \%$ of patients in the budesonide $3 \mathrm{mg}$ group (RR $1.12,95 \% \mathrm{Cl} 0.85$ to $1.47 ; 3$ studies, 180 patients). At 12 months $47 \%$ of patients in the budesonide $6 \mathrm{mg}$ group maintained remission compared to $39 \%$ of patients in the budesonide $3 \mathrm{mg}$ group (RR $1.18,95 \% \mathrm{Cl} 0.85$ to 1.65 3 studies, 180 patients). There was no significant heterogeneity across trials at any time point ( 3 months: $P=0.78,1^{2}=0 \% ; 6$ months: $\mathrm{P}=0.40, \mathrm{I}^{2}=0 \% ; 12$ months: $\mathrm{P}=0.58, \mathrm{I}^{2}=0 \%, \mathrm{)}$. GRADE analyses indicated that the overall quality of the evidence for these outcomes (maintenance of clinical remission at 3, 6 and 12 months) were moderate due to sparse data (109 events, 94 events and 77 events respectively, see Summary of findings 3 ).

\section{D) Budesonide $9 \mathrm{mg}$ versus budesonide $6 \mathrm{mg}$ (Analysis 5.1)}

One study (157 patients) compared parallel groups of $\mathrm{pH}$-modified release budesonide $9 \mathrm{mg}$ versus $6 \mathrm{mg}$ in patients who were induced by any means except surgical resection (de Jong 2007). Remission rates (defined here as the absence of disease relapse) were not significantly different between groups. At 12 months, $82 \%$ of patients in the budesonide $9 \mathrm{mg}$ group maintained remission compared to $76 \%$ of patients in the budesonide $6 \mathrm{mg}$ group (RR $1.07,95 \% \mathrm{Cl} 0.91$ to $1.26 ; \mathrm{P}=0.43$ ). A GRADE analysis indicated that the overall quality of the evidence for this outcome (maintenance of clinical remission at 12 months) was moderate due to sparse data (124 events, see Summary of findings 4).

E) Budesonide $9 \mathrm{mg}$ versus traditional corticosteroids (Analysis 6.1) One study (90 patients) compared CIR budesonide $9 \mathrm{mg}$ to prednisolone $40 \mathrm{mg} /$ day with a weaning schedule (Schoon 2005). Remission rates (defined by CDAl $\leq 200$ ) were not significantly different at 3 months, 6 months or 12 months. Fifty-nine per cent of patients in the budesonide group maintained remission at 3 months compared to $73 \%$ of prednisolone patients (RR 0.81 , $95 \mathrm{Cl} 0.60$ to 1.09). At 6 months, $52 \%$ of budesonide patients maintained remission compared to $66 \%$ of prednisolone patients (RR $0.79,95 \% \mathrm{Cl} 0.56$ to 1.12 ). At 12 months, $50 \%$ of budesonide patients maintained remission compared to $64 \%$ of prednisolone patients (RR $0.79,95 \% \mathrm{Cl} 0.55$ to 1.13 ). A GRADE analysis indicated that the overall quality of the evidence supporting this outcome (maintenance of clinical remission at 12 months) was low due to sparse data (51 events) and high risk of bias (lack of blinding, see Summary of findings 5).

\section{F) Budesonide $6 \mathrm{mg}$ versus mesalamine $3 \mathrm{~g}$ (Analysis 7.1)}

One study (57 patients) compared budesonide to $\mathrm{pH}$-dependent release mesalamine in patients with steroid-dependent $C D$ (Mantzaris 2003). Remission rates after one year of treatment (defined as the absence of disease relapse) were significantly higher in the budesonide group compared with mesalamine. Forty-five per cent $(13 / 29)$ of budesonide patients maintained remission at 12 months compared to $18 \%(5 / 28)$ of mesalamine patients (RR 2.51, $95 \% \mathrm{Cl} 1.03$ to 6.12 ). A GRADE analysis indicated that the overall quality of the evidence supporting this outcome (maintenance of clinical remission at 12 months) was very low due to very sparse data (18 events) and high risk of bias (no blinding, see Summary of findings 6$)$.

G) Budesonide 6 to $9 \mathrm{mg}$ versus azathioprine 2.0 to $2.5 \mathrm{mg} / \mathrm{kg}$ (Analysis 8.1)

One study (77 patients) compared CIR budesonide to azathioprine in patients with steroid-dependent CD (Mantzaris 2009). At 12 months, remission rates were not significantly different in the two treatment arms. Sixty-four per cent of budesonide patients maintained remission compared to $79 \%$ of azathioprine patients (RR $0.81,95 \% \mathrm{Cl} 0.61$ to 1.08 ). A GRADE analysis indicated that the overall quality of the evidence supporting this outcome (maintenance of clinical remission at 12 months) was very low due to sparse data (55 events) and high risk of bias (single-blind design and lack of allocation concealment, see Summary of findings 7).

\section{2) Change in CDAI from baseline values}

\section{A) Budesonide $6 \mathrm{mg}$ versus placebo (Analysis 1.2)}

Budesonide provided a modest benefit over placebo (as defined by a lower CDAl score) after 6 months (MD $-24.30,95 \% \mathrm{Cl}-46.31$ to -2.29 ) and 12 months (MD $-23.49,95 \% \mathrm{Cl}-46.65$ to -0.32 ). The change in CDAI scores was not significantly different after 3 months (MD -15.06, 95\% Cl -46.31 to 5.93; $\mathrm{P}=0.16$ ). Hellers 1999 enrolled patients with surgically induced remission and CDAl was assessed after 6 weeks of treatment or placebo. As such, changes in CDAI score were more modest in this study, and this may have accounted for the mild statistical heterogeneity noted at all three time points (3 months: $P=0.11,1^{2}=46 \% ; 6$ months: $P=0.10,1^{2}=48 \%$; 12 months: $\left.P=0.14,1^{2}=43 \%\right)$. A subgroup analysis including medically-induced patients resulted in the elimination of statistical heterogeneity ( 3 months: $P=0.59, \mathrm{I}^{2}=0 \% ; 6$ months: $\mathrm{P}=0.82, \mathrm{I}^{2}=$ $0 \% ; 12$ months: $P=0.40,12=0 \%)$ and a slight benefit in terms of the change in CDAl score at 3 months (MD $-25.27,95 \% \mathrm{Cl}-43.61$ to -6.94 ), 6 months (MD $-36.56,95 \% \mathrm{Cl}-55.50$ to -17.62 ), and 12 months (MD $-34.76,95 \% \mathrm{Cl}-55.42$ to -14.10$)$.

\section{B) Budesonide $3 \mathrm{mg}$ versus placebo (Analysis 2.2)}

The pooled analysis showed no significant benefit for change in CDAl score at 3 months (MD $-0.27,95 \% \mathrm{Cl}-15.19$ to 14.66 ), 6 months (MD $-4.70,95 \% \mathrm{Cl}-17.99$ to 8.60 ), or 12 months (MD $17.66,95 \%$ $\mathrm{Cl}-3.07$ to 38.39$)$. There was no heterogeneity across studies at 3 months $\left(P=0.52 ; 1^{2}=0.0 \%\right)$ or 6 months $\left(P=0.59 ; 1^{2}=0.0 \%\right)$ and low heterogeneity at 12 months $\left(P=0.28 ; 1^{2}=22 \%\right)$.

C) Budesonide $6 \mathrm{mg}$ versus budesonide $3 \mathrm{mg}$ (Analysis 4.2) 
The pooled analysis comparing $6 \mathrm{mg}$ to $3 \mathrm{mg}$ of CIR budesonide did not show any statistically significant difference in CDAI scores at 3 months (MD $-15.11,95 \% \mathrm{Cl}-41.10$ to 10.88 ) or 12 months (MD $-26.42,95 \% \mathrm{Cl}-69.55$ to 16.70 ). There was a slight benefit to $6 \mathrm{mg}$ compared with $3 \mathrm{mg}$ when CDAl score was assessed after 6 months of treatment (MD $-27.44,95 \% \mathrm{Cl}-52.09$ to -2.79 ). There was no significant heterogeneity across trials at either 3 months $(P=0.25$; $\left.1^{2}=37 \%\right)$ or 6 months $\left(P=0.29 ; 1^{2}=19 \%\right)$; there was significant heterogeneity across trials at 12 months $\left(P=0.05 ; 1^{2}=68 \%\right)$.

D) Budesonide $9 \mathrm{mg}$ versus budesonide $6 \mathrm{mg}$ (Analysis 5.2) Improvement in CDAl score was not significantly different between the groups treated with $9 \mathrm{mg}$ or $6 \mathrm{mg}$ of budesonide when assessed at 12 months (MD $-18.00,95 \% \mathrm{Cl}-41.06$ to 5.06 ). CDAl scores at 3 months and 6 months were also presented in the original article (de Jong 2007) and show no significant differences between the two doses at the latter two time points.

\section{E) Budesonide $9 \mathrm{mg}$ versus traditional corticosteroids}

In the study comparing CIR budesonide to prednisolone (Schoon 2005), baseline CDAl scores were similar between groups (137 in the budesonide group, 130 in the prednisolone group). Standard deviations were not available for these values at baseline, and the MD could not be calculated. However, CDAl scores at 3, 6 and 12 months were available and demonstrated no significant difference between groups. At 3 months, mean CDAl scores were $144 \pm 105$ in the budesonide group and $104 \pm 66$ in the prednisolone group. At 6 months, mean CDAl was $136 \pm 94$ in the budesonide group and 114 \pm 70 in the prednisolone group. At 12 months, mean CDAI was 144 \pm 102 in the budesonide group, and $125 \pm 76$ in the prednisolone group (data obtained from study author).

\section{F) Budesonide $6 \mathrm{mg}$ versus mesalamine $3 \mathrm{~g}$}

The study authors stated that CDAI was significantly lower in the budesonide group than in the mesalamine group at all time points (Mantzaris 2003), however the data were not presented in numerical form. The study authors could not be reached to provide further information.

\section{G) Budesonide 6 to $9 \mathrm{mg}$ versus azathioprine 2.0 to $2.5 \mathrm{mg} / \mathrm{kg}$}

Mantzaris 2009 was the only study to compare budesonide to azathioprine and did not report the change in CDAI.

\section{3) Mean time to relapse of disease}

A) Budesonide $6 \mathrm{mg}$ versus placebo (Analysis 1.3)

Budesonide $6 \mathrm{mg}$ significantly increased mean time to relapse relative to placebo (MD 59.93 days to relapse, $95 \% \mathrm{Cl} 19.02$ to 100.84). Statistically significant heterogeneity was found when studies were pooled $\left(P=0.07 ; 1^{2}=58 \%\right)$. Remission was induced as part of a clinical trial for all participating studies.

B) Budesonide $3 \mathrm{mg}$ versus placebo (Analysis 2.3)

When pooled, budesonide $3 \mathrm{mg}$ showed significant benefit over placebo for mean time to relapse (MD 30.80 days, $95 \% \mathrm{Cl} 8.88$ to $52.71)$, with no significant heterogeneity $\left(P=0.39 ;\left.\right|^{2}=2 \%\right)$.

C) Budesonide $6 \mathrm{mg}$ versus budesonide $3 \mathrm{mg}$ (Analysis 4.3) Mean time to relapse was not significantly different in patients who received $6 \mathrm{mg}$ compared with $3 \mathrm{mg}$ (MD 29.67 days; $95 \% \mathrm{Cl}-4.83$ to 64.18), with no significant heterogeneity $\left(P=0.51 ; 1^{2}=0 \%\right)$.
D) Budesonide $9 \mathrm{mg}$ versus budesonide $6 \mathrm{mg}$

The primary outcome of the study reporting this comparison was relapse-free survival (de Jong 2007). The published article reported median days to relapse with $95 \% \mathrm{Cl}$. The median time to relapse in the $6 \mathrm{mg}$ group was 809 days $(95 \% \mathrm{Cl} 360$ to 1259 days) and the median time to relapse in the $9 \mathrm{mg}$ group was 1049 days (95\% $\mathrm{Cl} 384$ to 1713 days). The study authors concluded there was no statistically significant difference between groups.

\section{E) Budesonide $9 \mathrm{mg}$ versus traditional corticosteroids} Schoon 2005 did not report the mean time to relapse.

\section{F) Budesonide $6 \mathrm{mg}$ versus mesalamine $3 \mathrm{~g}$}

Mantzaris 2003 did not report the mean time to relapse.

G) Budesonide 6 to $9 \mathrm{mg}$ versus azathioprine 2.0 to $2.5 \mathrm{mg} / \mathrm{kg}$ (Analysis 8.2)

The mean time to relapse was significantly shorter among those receiving budesonide as compared to those receiving azathioprine (MD -58.00; 95\% Cl-96.68 to -19.32).

\section{4) Study withdrawals due to treatment failure}

\section{A) Budesonide $6 \mathrm{mg}$ versus placebo (Analysis 1.4)}

Study withdrawals due to treatment failure were reported in six studies ( Cortot 2001; Ferguson 1998; Greenberg 1996; Hanauer 2005; Hellers 1999; Lofberg 1996). Two studies found a significant benefit for budesonide over placebo as defined by fewer withdrawals in the budesonide group: Cortot 2001 (RR 0.41, $95 \% \mathrm{Cl} 0.25$ to 0.69 ) and Hanauer 2005 (RR $0.57,95 \% \mathrm{Cl} 0.32$ to 1.00). The remaining studies found no significant difference. The pooled analysis showed no statistically significant difference in study withdrawals due to treatment failure between budesonide and placebo (RR $0.75,95 \% \mathrm{Cl} 0.55$ to 1.03 ). There was significant heterogeneity when studies were pooled $\left(P=0.05 ;\left.\right|^{2}=54 \%\right)$.

\section{B) Budesonide $3 \mathrm{mg}$ versus placebo (Analysis 2.4)}

There was no significant difference in study withdrawals due to treatment failure between budesonide and placebo (RR 1.02, 95\% $\mathrm{Cl} 0.84$ to 1.23$)$. There was no heterogeneity when studies were pooled $\left(P=0.38 ; 1^{2}=4 \%\right)$.

C) Budesonide $6 \mathrm{mg}$ versus budesonide $3 \mathrm{mg}$ (Analysis 4.4: Comparison 03, Outcome 04)

There was no significant difference in study withdrawals due to treatment failure between budesonide $6 \mathrm{mg}$ and budesonide $3 \mathrm{mg}$ (RR $0.89,95 \% \mathrm{Cl} 0.68$ to 1.16 ). There was no heterogeneity when studies were pooled $\left(P=0.37 ; 1^{2}=0 \%\right)$.

D) Budesonide $9 \mathrm{mg}$ versus budesonide $6 \mathrm{mg}$ (Analysis 5.3)

No significant difference was seen between $9 \mathrm{mg}$ and $6 \mathrm{mg}$ of budesonide when assessing study withdrawals due to treatment failure (RR $0.99,95 \% \mathrm{Cl} 0.55$ to 1.78 ).

E) Budesonide $9 \mathrm{mg}$ versus traditional corticosteroids (Analysis 6.2) Schoon 2005 reported study withdrawals due to disease deterioration or lack of improvement and these groups were considered to be withdrawals due to treatment failure for the purposes of this review. No significant difference in withdrawal rates between groups were noted (RR $1.65,95 \% \mathrm{Cl} 0.89$ to 3.06 ).

F) Budesonide $6 \mathrm{mg}$ versus mesalamine $3 g$ (Analysis 7.2)

In the single study comparing budesonide to mesalamine (Mantzaris 2003), patients receiving budesonide were less likely to 
withdraw from the study due to treatment failure (RR $0.67,95 \% \mathrm{Cl}$ 0.46 to 0.97 ).

G) Budesonide 6 to $9 \mathrm{mg}$ versus azathioprine 2.0 to $2.5 \mathrm{mg} / \mathrm{kg}$ (Analysis 8.3)

There were fewer withdrawals due to treatment failure among those receiving azathioprine compared to budesonide, but this difference was not statistically significant (RR $2.27,95 \% \mathrm{Cl} 0.98$ to 5.30).

\section{B. MEASURES OF SAFETY AND ADVERSE EVENTS}

\section{5) Proportion of patients with treatment-related adverse events at 12 months}

\section{A) Budesonide $6 \mathrm{mg}$ versus placebo (Analysis 1.5)}

Patients treated with budesonide $6 \mathrm{mg}$ had more treatment-related (as defined by the study physician) adverse events than those who received placebo. However, this difference was not statistically significant (RR $1.51,95 \% \mathrm{Cl} 0.90$ to 2.19 ). There was no significant heterogeneity when pooling these studies $(P=0.20 ; 12=34 \%)$.

B) Budesonide $3 \mathrm{mg}$ versus placebo (Analysis 2.5)

There was no significant difference in the proportion of patients experiencing adverse events in patients using budesonide $3 \mathrm{mg}$ compared to placebo (RR $1.19,95 \% \mathrm{Cl} 0.63$ to 2.24). There was significant heterogeneity when these studies were pooled $(P=0.09$; $\left.\mathrm{p}^{2}=50 \%\right)$.

C) Budesonide $6 \mathrm{mg}$ versus budesonide $3 \mathrm{mg}$ (Analysis 4.5) There was no significant difference in the proportion of patients experiencing adverse events in patients using budesonide $6 \mathrm{mg}$ compared to those receiving $3 \mathrm{mg}$ (RR $1.18,95 \% \mathrm{Cl} 0.60$ to 2.32; $\mathrm{P}$ $=0.64)$. There was no significant heterogeneity when these studies were pooled $\left(P=0.16 ; 1^{2}=45 \%\right)$.

D) Budesonide $9 \mathrm{mg}$ versus budesonide $6 \mathrm{mg}$ (Analysis 5.4) In the study comparing $9 \mathrm{mg}$ to $6 \mathrm{mg}$ of budesonide, there was no statistically significant difference in the proportion of patients experiencing at least one adverse event (RR $1.12,95 \% \mathrm{Cl} 0.89$ to 1.42).

\section{E) Budesonide $9 \mathrm{mg}$ versus traditional corticosteroids}

Schoon 2005 did not report the proportion of patients with treatment-related adverse events. However there was no difference between budesonide and weaning prednisolone groups in the proportion of patients with any adverse event (96\% versus $98 \%$ ), or serious adverse events ( $35 \%$ versus $29 \%$ ). There was a significantly lower rate of treatment-emergent corticosteroid adverse events in the budesonide group compared with prednisolone-treatment patients $(51 \%$ versus $71 \%$; $P<0.001)$.

\section{F) Budesonide $6 \mathrm{mg}$ versus mesalamine $3 \mathrm{~g}$}

Mantzaris 2003 did not report the proportion of patients experiencing at least one treatment-related adverse event. Three budesonide patients developed steroid-related adverse events (acne and moon facies). Steroid-related adverse events were reduced in both groups after discontinuation of the systemic corticosteroid.

G) Budesonide 6-9 mg versus azathioprine $2.0-2.5 \mathrm{mg} / \mathrm{kg}$
Mantzaris 2009 did not report the proportion of patients in each group with a treatment-related adverse event. There were 112 adverse events reported among participants receiving azathioprine and 83 among those receiving budesonide. Among those receiving budesonide, one patient developed acne, five developed moon face, and one experienced hair loss. Two patients were withdrawn from the azathioprine arm of the trial due to the development of pancreatitis and leukopenia; an additional two patients developed paresthesias, one developed hair loss, and one had elevated transaminases.

\section{6) Study withdrawals due to adverse events}

A) Budesonide $6 \mathrm{mg}$ versus placebo (Analysis 1.6)

There was no significant increase in the proportion of patients withdrawing from studies due to adverse events in the budesonide groups compared to placebo (RR $1.08,95 \% \mathrm{Cl} 0.60$ to 1.95). There was no heterogeneity when studies were pooled $\left(P=0.62 ; 1^{2}=0 \%\right)$.

B) Budesonide $3 \mathrm{mg}$ versus placebo (Analysis 2.6)

There was no significant increase in the proportion of patients withdrawing from studies due to adverse events in the budesonide groups compared with placebo ( $\mathrm{RR} 0.66,95 \% \mathrm{Cl} 0.20$ to 2.17 ). There was no heterogeneity when studies were pooled $(P=0.62,12=0 \%)$.

C) Budesonide $6 \mathrm{mg}$ versus budesonide $3 \mathrm{mg}$ (Analysis 4.6)

In the two studies that compared budesonide $6 \mathrm{mg}$ with $3 \mathrm{mg}$ and placebo, Lofberg 1996 reported no withdrawals due to adverse events and Ferguson 1998 reported one withdrawal due to adverse events in each trial arm (RR $1.18,95 \% \mathrm{Cl} 0.08$ to 17.82). There was no heterogeneity across studies $\left(P>0.99 ; 1^{2}=0 \%\right)$.

D) Budesonide $9 \mathrm{mg}$ versus budesonide $6 \mathrm{mg}$ (Analysis 5.5)

In the study examining $9 \mathrm{mg}$ and $6 \mathrm{mg}$ of budesonide (de Jong 2007), there was no significant difference between groups in withdrawals due to adverse events (RR $0.31,95 \% \mathrm{Cl} 0.03$ to 2.94 ).

E) Budesonide $9 \mathrm{mg}$ versus traditional corticosteroids (Analysis 6.3) In the study comparing budesonide to weaning prednisolone (Schoon 2005), there were no withdrawals in the steroid group compared with four withdrawals in the budesonide group, however, this difference was not statistically significant (RR 8.62, $95 \% \mathrm{Cl} 0.48$ to 155.52 ).

F) Budesonide $6 \mathrm{mg}$ versus mesalamine $3 \mathrm{~g}$

Mantzaris 2003 did not report any withdrawals due to adverse events.

G) Budesonide 6 to $9 \mathrm{mg}$ versus azathioprine 2.0 to $2.5 \mathrm{mg} / \mathrm{kg}$ (Analysis 8.4)

In Mantzaris 2009, there were no withdrawals due to adverse events in the budesonide arm and two in the azathioprine arm (RR 0.19, $95 \% \mathrm{Cl} 0.01$ to 3.93$)$.

H) Sensitivity Analysis - Any dose or formulation of budesonide compared with placebo (Analysis 3.1)

When all studies comparing budesonide (any dose or formulation) to placebo were pooled, there was no statistically significant difference in study withdrawals due to adverse events between patients receiving active treatment compared to placebo (RR 0.81 , $95 \% \mathrm{Cl} 0.48$ to 1.36$)$. There was no heterogeneity when studies were pooled $\left(P=0.71 ;\left.\right|^{2}=0 \%\right)$. 
7) Proportion of patients with abnormal ACTH stimulation test Note: The definition of an 'abnormal' test is reported for each study in the table 'Characteristics of included studies'.

\section{A) Budesonide $6 \mathrm{mg}$ versus placebo (Analysis 1.7)}

Patients receiving CIR budesonide $6 \mathrm{mg}$ per day had significantly higher rates of abnormal ACTH stimulation tests than those receiving placebo ( $\mathrm{RR} 2.72,95 \% \mathrm{Cl} 1.62$ to 4.58). There was no heterogeneity when the studies were pooled $\left(P=0.37 ; 1^{2}=5 \%\right)$. No studies in this comparison used the $\mathrm{pH}$-dependent formulation.

\section{B) Budesonide $3 \mathrm{mg}$ versus placebo (Analysis 2.7)}

Patients receiving CIR budesonide $3 \mathrm{mg}$ per day had higher rates of abnormal ACTH stimulation tests than those receiving placebo (RR $1.89,95 \% \mathrm{Cl} 0.76$ to 4.69 ). There was low heterogeneity when the studies were pooled $\left(P=0.26 ; 1^{2}=27 \%\right)$. No studies in this comparison used the $\mathrm{pH}$-dependent formulation.

C) Budesonide $6 \mathrm{mg}$ versus budesonide $3 \mathrm{mg}$ (Analysis 4.7: Comparison 03, Outcome 07)

There was no significant difference in abnormal ACTH stimulation tests between $6 \mathrm{mg}$ and $3 \mathrm{mg}$ CIR budesonide (RR 1.49, 95\% Cl 1.00 to 2.24). There was no heterogeneity when studies were pooled ( $P$ $=0.96 ; 1^{2}=0 \%$ ).

D) Budesonide $9 \mathrm{mg}$ versus budesonide $6 \mathrm{mg}$

de Jong 2007 did not report the proportion of patients with abnormal ACTH stimulation.

E) Budesonide $9 \mathrm{mg}$ versus traditional corticosteroids (Analysis 6.4) There was no significant difference in ACTH stimulation test between budesonide and prednisolone, although there was a trend towards increased abnormal tests in the prednisolone group (RR $0.60,95 \% \mathrm{Cl} 0.36$ to 1.00$)$.

F) Budesonide $6 \mathrm{mg}$ versus mesalamine $3 \mathrm{~g}$

Mantzaris 2003 did not report on ACTH stimulation tests.

\section{G) Budesonide 6 to $9 \mathrm{mg}$ versus azathioprine 2.0 to $2.5 \mathrm{mg} / \mathrm{kg}$}

Mantzaris 2009 reported significant decreases in cortisol levels following treatment with budesonide, but mean cortisol levels remained within the normal range. No numerical values are provided and the proportion of patients with abnormal ACTH stimulation tests in each arm was not reported.

\section{OTHER OUTCOMES}

\section{Quality of life (IBDQ)}

Most studies did not report quality of life measures. The remaining studies were not pooled to analyze change in IBDQ scores because each study compared budesonide to a different control and some scores and standard deviations were not reported.

\section{A) Budesonide versus placebo}

Greenberg 1996 reported no significant group differences in the change of IBDQ at any time point. Baseline IBDQ scores were $181 \pm$ 19 in the placebo group, $185 \pm 21$ in the budesonide $3 \mathrm{mg}$ group and $184 \pm 24$ in the budesonide $6 \mathrm{mg}$ group. After one year, the placebo group had a mean IBDQ score of $150 \pm 38$, the $3 \mathrm{mg}$ group had a mean score of $156 \pm 39$ and the $6 \mathrm{mg}$ group had a mean score of 161 \pm 36 .
Cortot 2001 described a significant difference in mean IBDQ scores after 13 weeks of treatment with similar baselines, citing a P-value of 0.025 . Cortot 2001 also administered the SF-36 questionnaire and found a significant improvement in the physical component for the budesonide group, but no difference between groups in the mental component. Raw data on IBDQ and SF-36 questionnaires were not available after contact with study authors.

\section{B) Budesonide versus prednisolone}

Schoon 2005 reported no significant differences in mean IBDQ scores at 6 months (168 \pm 37 in the budesonide group, $164 \pm 34$ in the prednisolone group) or 12 months ( $172 \pm 36$ in the budesonide group, $167 \pm 36$ in the prednisolone group).

\section{C) Budesonide versus mesalamine}

Mantzaris 2003 reported a significantly better IBDQ score in the budesonide group compared to mesalamine. At baseline, mean IBDQ scores were similar ( $188 \pm 18$ in the budesonide group, $186 \pm 12$ in the mesalamine group), but after one year the budesonide group had significantly higher IBDQ scores than the mesalamine group (150 \pm 44 in the budesonide group, $113 \pm 33$ in the mesalamine group, $\mathrm{P}<0.0001$ ).

\section{DISCUSSION}

Oral budesonide is a corticosteroid designed to be topically released in the small intestine with a high first-pass effect, limiting systemic adverse events. It is effective for induction of remission in $C D$ with fewer adverse effects than traditional corticosteroids (Seow 2008). However, the results of this review suggest that budesonide is not effective for maintaining remission in $C D$ patients compared to placebo in the long-term. For the placebo-controlled studies a GRADE analysis rated the overall quality of the evidence for continued remission at 6 and 12 months as moderate due to sparse data (See Summary of findings for the main comparison). However, budesonide significantly increased the mean time to relapse compared to placebo. This is true of both drug formulations (CIR or pH-dependent) and for both methods used to induce remission (pharmacological or surgical). Additionally, although adverse events did not appear to be more common than placebo in the studies reviewed, the risk of budesonide affecting the adrenocorticoid axis is demonstrated by higher rates of abnormal ACTH stimulation tests.

At three months, budesonide demonstrated a modest benefit over placebo at doses of both $3 \mathrm{mg}$ and $6 \mathrm{mg}$, but this benefit was not sustained at 6 and 12 months. Significant heterogeneity was observed among the trials comparing $6 \mathrm{mg}$ of budesonide to placebo. Removing trials of surgically-induced patients decreased between-study heterogeneity and removing studies of both surgically-induced and steroid-dependent patients completely removed statistical heterogeneity. When the trial of surgicallyinduced patients was excluded, budesonide demonstrated significant benefit over placebo. This effect was likely driven by the one trial of steroid-dependent patients that found a significant benefit of budesonide $6 \mathrm{mg}$ over placebo but only followed patients for three months (Cortot 2001). Therefore the benefit seen at three months following enrolment may have been influenced by the methods used to induce remission prior to study enrolment. These findings support suggestions that $C D$ may not be one disease but in fact a broad spectrum of diseases, as indicated by the 
different patient populations in the different trials (Ruel 2014). Budesonide may have different efficacy across different subtypes of CD. Comparison of budesonide $3 \mathrm{mg}$ to placebo identified no statistical heterogeneity across trials; this comparison included one trial of surgically-induced patients (Ewe 1999), and no trial of steroid-dependent patients.

The four studies which compared different doses of budesonide (6 mg versus $3 \mathrm{mg}$ in three studies:Ferguson 1998, Greenberg 1996, and Lofberg 1996 and 9 mg versus $6 \mathrm{mg}$ in one study: de Jong 2007) did not demonstrate any benefit for higher doses of budesonide. While no study has compared budesonide $9 \mathrm{mg}$ to placebo for maintenance of remission, this higher dose has been shown to be effective for induction of remission in CD patients (Seow 2008). Nevertheless, there is no evidence that higher doses are more effective than lower doses.

The definition of remission was not consistent across all studies. Most studies defined sustained remission as a CDAl of less than or equal to 150 at each follow-up time point. Other studies reported only relapse rates defined as a CDAl of greater than 150 or 200 with a minimum 60 point increase from baseline (Cortot 2001; de Jong 2007; Ewe 1999; Gross 1998; Mantzaris 2003). Clinical remission was not defined in the study comparing budesonide to azathioprine (Mantzaris 2009). For the purposes of this review, in the cases where remission rates were not reported or obtainable from study authors, the proportion of patients in remission at each time point was defined as the inverse of the relapse rate at that time point. Only one study comparing budesonide $6 \mathrm{mg}$ to placebo reported relapse rates (Cortot 2001). This study was the only one to include steroid-dependent patients and had higher rates of remission relative to those that included patients induced as part of a clinical trial. Prednisolone was tapered over time and may have prolonged remission and contributed to both the magnitude of the effect and heterogeneity across studies. Relapse rates were reported after only 13 weeks of treatment. The different inclusion criteria compared to other studies in the analysis and the short follow-up time may have accounted for the benefit attributed to budesonide. The results of the studies comparing $3 \mathrm{mg}$ to placebo reported only relapse rates (Ewe 1999; Gross 1998), and were consistent with the studies reporting remission rates. No appreciable heterogeneity was detected when studies were pooled. The subgroup analysis of studies using the $\mathrm{pH}$-modified form of budesonide reported relapse rates only and budesonide had no benefit over placebo.

Budesonide decreased CDAl scores relative to placebo at the $6 \mathrm{mg}$ daily dose. This benefit amounts to less than 40 points on the CDAI scale at all assessed time points and is unlikely to be clinically significant. Most clinical trials consider changes in CDAl score of 70 to 100 points to be the minimum clinically important change (Sands 2005; Su 2007). Among patients that relapse, budesonide $6 \mathrm{mg}$ extends the time to disease recurrence by 60 days and $3 \mathrm{mg}$ extends the time to disease recurrence by 30 days.

Budesonide was also compared to conventional steroids (weaning dose of prednisolone) in a single unblinded trial. The results of this study should be interpreted with caution as a GRADE analyses rated the overall quality of the evidence for continued remission at 12 months as low due to high risk of bias (i.e. no blinding) and sparse data. The results of this study may have been subject to detection bias. Despite issues related to study quality, there were no differences between budesonide and prednisolone both in terms of efficacy (i.e., maintenance of remission) or safety (withdrawals due to adverse events). However, budesonide was safer than prednisolone in terms of impact on the adrenocortical axis with significantly less budesonide-patients experiencing abnormal ACTH stimulation tests than those treated with prednisolone.

One small study found budesonide to be superior to mesalamine for maintenance of remission, and was associated with fewer withdrawals due to adverse events. The results of this study should be interpreted with caution as a GRADE analysis rated the overall quality of the evidence for continued remission at 12 months as very low due to high risk of bias (i.e. no blinding) and very sparse data (18 events). There was no significant difference in continued remission at 12 months between azathioprine and budesonide. Azathioprine increased the time to disease recurrence among patients who relapsed. The results of this study should be interpreted with caution as a GRADE analysis rated the overall quality of the evidence for continued remission at 12 months as very low due to high risk of bias (i.e. single-blind design and lack of allocation concealment) and sparse data. The failure to blind trial participants leads to performance bias and may partly explain the results of these trials. The failure to adequately conceal allocation in the trial comparing budesonide to azathioprine may have exaggerated the differences between budesonide and azathioprine (Egger 2001).

While budesonide did not increase the risk of adverse events relative to placebo or any active comparators, any dose increased the risk of an abnormal ACTH test compared to placebo. However, there does appear to be dose-dependent suppression of the adrenocortical axis, with those receiving $6 \mathrm{mg}$ being numerically more likely to have an abnormal ACTH stimulation test than those receiving $3 \mathrm{mg}$. This comparison was not available for the study comparing $9 \mathrm{mg}$ to $6 \mathrm{mg}$. Abnormal ACTH stimulation tests were less common among patients receiving budesonide compared to conventional steroids.

These results demonstrate that budesonide, when used for long periods, has systemic effects. This could have important implications for at risk patients including growing children and adults with osteopenia or osteoporosis, although these systemic effects appear to be less pronounced with budesonide than conventional steroids. Schoon 2005 compared budesonide to conventional steroids, with the primary outcome being bone mineral density (as measured by DXA). Among corticosteroid-naive patients, decreases in bone mineral density were less pronounced following treatment with budesonide than prednisolone. However, the effect of budesonide on bone mineral density remains inconclusive (Cino 2002). No randomized clinical trial has compared changes in bone mineral density between budesonide and placebo. The risk of systemic corticosteroid effects in light of these limited benefits make the use of budesonide for maintenance of remission difficult to justify. Additionally, selection bias may also play a role in these minor benefits, as patients were often included in maintenance trials only if they had previously responded to budesonide during a trial for induction of remission.

The reasons for budesonide's lack of efficacy for maintenance of remission in CD are not entirely clear. There is evidence that the use of systemic corticosteroids may contribute to the loss of immune tolerance, potentially due to reduced immune cell apoptosis (Towers 2005). The early use of corticosteroids may, in fact, propagate the abnormal immune response in patients with 
$C D$ resulting in repeated episodes of inflammation and tissue damage, as well as decreased efficacy of corticosteroids with repeated or long-term use (Van Den Brande 2002). It is also possible that the location of disease in patients receiving budesonide who relapse is outside of the location of budesonide's greatest effect (the ileocecal region). Only two studies reported endoscopic recurrence both reporting only recurrences at the neo-terminal ileum or anastomotic site in patients who had a surgically-induced remission (Ewe 1999; Hellers 1999).

\section{AUTHORS' CONCLUSIONS}

\section{Implications for practice}

These data suggest budesonide is not effective for maintenance of remission in $C D$, particularly when used beyond three months following induction of remission. However, it has a modest benefit in terms of decreasing the CDAl score and prolonging time to relapse. Any mild benefits are outweighed by the risk of adrenocorticoid suppression when using budesonide for extended periods of time. Patients receiving $6 \mathrm{mg}$ daily of budesonide for extended periods of time experienced a higher rate of treatmentrelated adverse events, although these events did not result in study withdrawal and therefore may have been relatively mild.

\section{Implications for research}

The results of this review demonstrated no benefit for budesonide for the maintenance of remission in CD. Studies included in this review examined different doses $(9 \mathrm{mg}, 6 \mathrm{mg}$, and $3 \mathrm{mg}$ daily), formulations (CIR and $\mathrm{pH}$-dependent release) and modes of remission induction (e.g., systemic corticosteroids, budesonide and surgical resection). Additionally, higher doses of budesonide (9 $\mathrm{mg}$ vs. $6 \mathrm{mg}$ or $6 \mathrm{mg}$ vs. $3 \mathrm{mg}$ ) do not appear to provide any additional benefit. The only comparison lacking amongst these studies is that of budesonide $9 \mathrm{mg}$ compared with placebo for maintenance of remission. However, considering the lack of benefit of $9 \mathrm{mg}$ over $6 \mathrm{mg}$ (de Jong 2007), and the higher rates of adrenocorticoid axis suppression such a trial is unlikely to be undertaken. Further information on the long-term implications of budesonide on bone mineral density would be beneficial.

\section{ACKNOWLEDGEMENTS}

The authors are grateful to Ms. Lorinda Simms who conducted the original meta-analysis on this subject matter for the Cochrane Collaboration. The authors would also like to thank Dr. Tore Persson (Astra Zeneca R\&D, Lund, Sweden) Dr. Erik Schoon (Department of Gastroenterology, Catharina Hospital, Eindhoven, The Netherlands) and Dr. Roland Greinwald (Dr. Falk Pharma $\mathrm{GmbH}$, Freiburg, Germany) for providing unpublished raw data from the studies described above.

Funding for the IBD/FBD Review Group (September 1, 2010 - August $31,2015)$ has been provided by the Canadian Institutes of Health Research (CIHR) Knowledge Translation Branch (CON - 105529) and the CIHR Institutes of Nutrition, Metabolism and Diabetes (INMD); and Infection and Immunity (III) and the Ontario Ministry of Health and Long Term Care (HLTC3968FL-2010-2235).

Miss Ila Stewart has provided support for the IBD/FBD Review Group through the Olive Stewart Fund. 


\section{RE F E R E N C E S}

\section{References to studies included in this review}

Cortot 2001 \{published data only\}

Cortot A, Colombel JF, Rutgeerts P, Lauritsen K, Malchow H, Hamling J, et al. Switch from systemic steroids to budesonide in steroid dependent patients with inactive Crohn's disease. Gut 2001;48(2):186-90.

\section{de Jong 2007 \{published data only\}}

de Jong DJ, Bac DJ, Tan G, de Boer SY, Grabowsky IL, Jansen JB, et al. Maintenance treatment with budesonide $6 \mathrm{mg}$ versus 9 $\mathrm{mg}$ once daily in patients with Crohn's disease in remission. Netherlands Journal of Medicine 2007;65(9):339-45.

\section{Ewe 1999 \{published data only\}}

Ewe K, Bottger T, Buhr HJ, Ecker KW, Otto HF. Low-dose budesonide treatment for prevention of postoperative recurrence of Crohn's disease: a multicentre randomized placebo-controlled trial. German Budesonide Study Group. European Journal of Gastroenterology and Hepatology 1999;11(3):277-82.

\section{Ferguson 1998 \{published and unpublished data\}}

Ferguson A, Campieri M, Doe W, Persson T, Nygard G. Oral budesonide as maintenance therapy in Crohn's disease-results of a 12-month study. Global Budesonide Study Group. Alimentary Pharmacology and Therapeutics 1998;12(2):175-83.

Greenberg 1996 \{published and unpublished data\} Greenberg GR, Feagan BG, Martin F, Sutherland LR, Thomson AB, Williams CN, et al. Oral budesonide as maintenance treatment for Crohn's disease: a placebocontrolled, dose-ranging study. Canadian Inflammatory Bowel Disease Study Group. Gastroenterology 1996;110(1):45-51.

Gross 1998 \{published and unpublished data\}

Gross V, Andus T, Ecker KW, Raedler A, Loeschke K, Plauth M, et al. Low dose oral $\mathrm{pH}$ modified release budesonide for maintenance of steroid induced remission in Crohn's disease. The Budesonide Study Group. Gut 1998;42(4):493-6.

Hanauer 2005 \{published and unpublished data\}

Hanauer S, Sandborn WJ, Persson A, Persson T. Budesonide as maintenance treatment in Crohn's disease: a placebocontrolled trial. Alimentary Pharmacology and Therapeutics 2005;21(4):363-71.

\section{Hellers 1999 \{published and unpublished data\}}

Hellers G, Cortot A, Jewell D, Leijonmarck CE, Lofberg R, Malchow $\mathrm{H}$, et al. Oral budesonide for prevention of postsurgical recurrence in Crohn's disease. The IOIBD Budesonide Study Group. Gastroenterology 1999;116(2):294-300.

\section{Lofberg 1996 \{published and unpublished data\}}

Lofberg R, Rutgeerts P, Malchow H, Lamers C, Danielsson A, Olaison $\mathrm{G}$, et al. Budesonide prolongs time to relapse in ileal and ileocaecal Crohn's disease. A placebo controlled one year study. Gut 1996;39(1):82-6.
Mantzaris 2003 \{published data only\}

Mantzaris GJ, Petraki K, Sfakianakis M, Archavlis E, Christidou A, Chadio-lordanides $\mathrm{H}$, et al. Budesonide versus mesalamine for maintaining remission in patients refusing other immunomodulators for steroid-dependent Crohn's disease. Clinical Gastroenterology and Hepatology 2003;1(2):122-8.

Mantzaris 2009 \{published data only\}

Mantzaris GJ, Christidou A, Sfakianakis M, Roussos A, Koilakou S, Petraki K, Polyzou P. Azathioprine is superior to budesonide in achieving and maintaining mucosal healing and histologic remission in steroid-dependent Crohn's disease. Inflammatory Bowel Diseases 2009;15(3):375-82.

Schoon 2005 \{published and unpublished data\}

Schoon EJ, Bollani S, Mills PR, Israeli E, Felsenberg D, Ljunghall $\mathrm{S}$, et al. Bone mineral density in relation to efficacy and side effects of budesonide and prednisolone in Crohn's disease. Clinical Gastroenterology and Hepatology 2005;3(2):113-21.

\section{References to studies excluded from this review}

Dignass 2014 \{published data only\}

Dignass A, Stoynov S, Dorofeyev AE, Grigorieva GA, Tomsova E, Altorjay I, et al. Once versus three times daily dosing of oral budesonide for active Crohn's disease: A double-blind, double-dummy, randomized trial. Journal of Crohn's and Colitis 2014 Feb 14. pii: S1873-9946(14)00040-3. doi: 10.1016/ j.crohns.2014.01.021. [Epub ahead of print].

Ecker 2003 \{published data only\}

Ecker KW, Stallmach A, Seitz G, Gierend M, Greinwald R, Achenbach U. Oral budesonide significantly improves water absorption in patients with ileostomy for Crohn disease. Scandinavian Journal of Gastroenterology 2003;38(3):288-93.

Green 2001 \{published data only\}

Green JR, Lobo AJ, Giaffer M, Travis S, Watkins HC, Freedom Investigator Group. Maintenance of Crohn's disease over 12 months: fixed versus flexible dosing regimen using budesonide controlled ileal release capsules. Alimentary Pharmacology and Therapeutics 2001;15(9):1331-41.

Levine 2009 \{published data only\}

Levine A, Kori M, Dinari G, Broide E, Shaoul R, Yerushalmi B, et al. Comparison of two dosing methods for induction of response and remission with oral budesonide in active pediatric Crohn's disease: a randomized placebo-controlled trial. Inflammatory Bowel Diseases Jul 2009;15(7):1055-61.

Pohl 1997 \{published data only\}

Pohl C, Kruis W. Oral budesonide - A further step in the prevention of relapse in Crohn's disease? [German]. Leber, Magen, Darm 1997;27(4):235-9. 
Sandborn 2005 \{published data only\}

Sandborn WJ, Lofberg R, Feagan BG, Hanauer SB, Campieri M, Greenberg GR. Budesonide for maintenance of remission in patients with Crohn's disease in medically induced remission: a predetermined pooled analysis of four randomized, double-blind, placebo-controlled trials. American Journal of Gastroenterology 2005;100(8):1780-7.

\section{Suzuki 2013 \{published data only\}}

Suzuki Y, Motoya S, Takazoe M, Kosaka T, Date M, Nii M, et al. Efficacy and tolerability of oral budesonide in Japanese patients with active Crohn's disease: a multicentre, doubleblind, randomized, parallel-group phase II study. Journal of Crohn's and Colitis 2013;7(3):239-47.

Tromm 2011 \{published data only\}

Tromm A, Bunganic I, Tomsova E, Tulassay Z, Lukas M, Kykal J, et al. Budesonide $9 \mathrm{mg}$ is at least as effective as mesalamine 4.5 $\mathrm{g}$ in patients with mildly to moderately active Crohn's disease. Gastroenterology 2011;140(2):425-34.

\section{References to ongoing studies}

NCT01453946 \{published data only\}

Safety and maintenance study of entocort for children with Crohn's disease. Ongoing study December 2011.

\section{Additional references}

\section{Barnes 1993}

Barnes PJ, Adcock I. Anti-inflammatory actions of steroids: molecular mechanisms. Trends in Pharmacological Sciences 1993;14(12):436-41.

\section{Baumgart 2007}

Baumgart DC, Sandborn WJ. Inflammatory bowel disease: clinical aspects and established and evolving therapies. Lancet 2007;369(9573):1641-57.

\section{Best 1976}

Best WR, Becktel JM, Singleton JW, Kern F Jr. Development of a Crohn's disease activity index. National Cooperative Crohn's Disease Study. Gastroenterology 1976;70(3):439-44.

\section{Bousvaros 2007}

Bousvaros A, Antonioli DA, Colletti RB, Dubinsky MC, Glickman JN, Gold BD, et al. Differentiating ulcerative colitis from Crohn disease in children and young adults: report of a working group of the North American Society for Pediatric Gastroenterology, Hepatology, and Nutrition and the Crohn's and Colitis Foundation of America. Journal of Pediatric Gastroenterology and Nutrition 2007;44(5):653-74.

\section{Cino 2002}

Cino M, Greenberg GR. Bone mineral density in Crohn's disease: a longitudinal study of budesonide, prednisone, and nonsteroid therapy. American Journal of Gastroenterology 2002;97(4):915-21.

\section{D'Haens 1998}

D'Haens GR, Geboes K, Peeters M, Baert F, Pennickx F, Rutgeerts $P$. Early lesions of recurrent Crohn's disease caused by infusion of intestinal contents in excluded ileum. Gastroenterology 1998;114(2):262-7.

\section{DerSimonian 1986}

DerSimonian R, Laird N. Meta-analysis in clinical trials. Controlled Clinical Trials 1986;7(3):177-88.

\section{Egger 2001}

Juni P, Altman DG, Egger M. Assessing the quality of randomised controlled trials. In: Egger M, Smith GD, Altman DG editor(s). Systematic reviews in health care: meta-analysis in context. London: BMJ Publishing Group, 2001.

\section{Fedorak 2005}

Fedorak RN, Bistritz L. Targeted delivery, safety, and efficacy of oral enteric-coated formulations of budesonide. Advanced Drug Delivery Reviews 2005;57(2):303-16.

\section{Guyatt 2008}

Guyatt GH, Oxman AD, Vist GE, Kunz R, Falck-Ytter Y, AlonsoCoello $P$, et al. GRADE: an emerging consensus on rating quality of evidence and strength of recommendations. $B M J$ 2008;336(7650):924-6.

\section{Harvey 1980}

Harvey RF, Bradshaw JM. A simple index of Crohn's-disease activity. Lancet 1980;1(8167):514.

\section{Higgins 2003}

Higgins JP, Thompson SG, Deeks JJ, Altman DG. Measuring inconsistency in meta-analyses. BMJ 2003;327(7414):557-60.

\section{Higgins 2011}

Higgins JPT, Altman DG, Sterne JAC (editors). Chapter 8: Assessing risk of bias in included studies. Cochrane Handbook for Systematic Reviews of Interventions Version 5.1.0 (updated March 2011). The Cochrane Collaboration, 2011. Available from www.cochrane-handbook.org.

\section{Hyams 1991}

Hyams JS, Ferry GD, Mandel FS, Gryboski JD, Kibort PM, Kirschner BS, et al. Development and validation of a pediatric Crohn's disease activity index. Journal of Pediatric Gastroenterology and Nutrition 1991;12(4):439-47.

\section{Hyams 2000}

Hyams JS. Corticosteroids in the treatment of gastrointestinal disease. Current Opinion in Pediatrics 2000;12(5):451-5.

\section{Hyams 2005}

Hyams JS. Inflammatory bowel disease. Pediatrics in Review 2005;26(9):314-20.

\section{Lewis 2008}

Lewis JD, Gelfand JM, Troxel AB, Forde KA, Newcomb C, Kim H, et al. Immunosuppressant medications and mortality in inflammatory bowel disease. American Journal of Gastroenterology 2008;103(6):1428-35; quiz 1436. 


\section{Malchow 1984}

Malchow H, Ewe K, Brandes JW, Goebell H, Ehms H, Sommer H, et al. European Cooperative Crohn's Disease Study (ECCDS): results of drug treatment. Gastroenterology 1984;86(2):249-66.

\section{Mary 1989}

Mary JY, Modigliani R. Development and validation of an endoscopic index of severity of Crohn's disease: a prospective multicentre study. Groupe d'Etudes Thérapeutiques des Affections Inflammatoires du Tube Digestif (GETAID). Gut 1989;30(7):983-9.

\section{Ruel 2014}

Ruel J, Ruane D, Mehandru S, Gower-Rousseau C, Colombel JF. IBD across the age spectrum-is it the same disease?. Nature Reviews. Gastroenterology and Hepatology 2014;11(2):88-98.

\section{Rutgeerts 1990}

Rutgeerts P, Geboes K, Vantrappen G, Beyls J, Kerremans R, Hiele M. Predictability of the postoperative course of Crohn's disease. Gastroenterology 1990;99(4):956-63.

\section{Sands 2005}

Sands BE, Abreu MT, Ferry GD, Griffiths AM, Hanauer SB, Isaacs KL, et al. Design issues and outcomes in IBD clinical trials. Inflammatory Bowel Diseases 2005;11(Suppl 1):S22-8.

\section{Schünemann 2011}

Schünemann HJ, Oxman AD, Vist GE, Higgins JPT, Deeks JJ, Glasziou P, et al. Chapter 12: Interpreting results and drawing conclusions. In: Higgins JPT, Green S editor(s). Cochrane Handbook for Systematic Reviews of Interventions Version 5.1.0 (updated March 2011). The Cochrane Collaboration, 2011. Available from www.cochrane-handbook.org.

\section{Seow 2008}

Seow CH, Benchimol El, Griffiths AM, Otley AR, Steinhart AH. Budesonide for induction of remission in Crohn's disease. Cochrane Database of Systematic Reviews 2008, Issue 3. [DOI: 10.1002/14651858.CD000296.pub3]

\section{Stockbrugger 2003}

Stockbrugger RW, Schoon E, Bollani S, Israeli E, Persson T, Bengtsson $\mathrm{B}$, et al. Budesonide versus prednisolone in the

\section{CHARACTERISTICS OF STUDIES}

Characteristics of included studies [ordered by study ID] management of Crohn's disease: a randomized multi-national 2-year study. Gastroenterology 2003;124(4 Supp 1):A26.

\section{Su 2007}

Su C, Lewis JD, Goldberg B, Brensinger C, Lichtenstein GR. A meta-analysis of the placebo rates of remission and response in clinical trials of active ulcerative colitis. Gastroenterology 2007;132(2):516-26.

\section{Towers 2005}

Towers R, Naftali T, Gabay G, Carlebach M, Klein A, Novis B. High levels of glucocorticoid receptors in patients with active Crohn's disease may predict steroid resistance. Clinical and Experimental Immunology 2005;141(2):357-62.

\section{Van Den Brande 2002}

Van Den Brande JM, Peppelenbosch MP, Van Deventer SJ. Treating Crohn's disease by inducing T lymphocyte apoptosis. Annals of the New York Academy of Sciences 2002;973:166-80.

\section{van Hees 1980}

van Hees PA, van Elteren PH, van Lier HJ, van Tongeren JH. An index of inflammatory activity in patients with Crohn's disease. Gut 1980;21(4):279-86.

\section{Yang 2002}

Yang YX, Lichtenstein GR. Corticosteroids in Crohn's disease. American Journal of Gastroenterology 2002;97(4):803-23.

\section{References to other published versions of this review}

\section{Benchimol 2009}

Benchimol El, Seow CH, Otley AR, Steinhart AH. Budesonide for maintenance of remission in Crohn's disease. Cochrane Database of Systematic Reviews 2009, Issue 1. [DOI: 10.1002/14651858.CD002913.pub2]

\section{Simms 2001}

Simms L, Steinhart AH. Budesonide for maintenance of remission in Crohn's disease. Cochrane Database of Systematic Reviews 2001, Issue 1. [DOI: 10.1002/14651858.CD002913]

Cortot 2001

Methods Randomized, controlled, double-blind, multicenter trial

Participants

Patients $>18$ years of age with $\mathrm{CDAI} \leq 200$ who were steroid-dependent $(\mathrm{N}=120)$

Patients received azathioprine for a minimum of 6 months and 5-aminosalicylates for a minimum of 1 month

METHOD OF INDUCTION OF REMISSION: All patients had been receiving prednisolone or prednisone 10-30 mg/day, six months prior to the study with at least two attempts to taper the dose with subsequent relapses resulting 
Cortot 2001 (Continued)

EXCLUSION CRITERIA: 1) Pregnant or breast-feeding women, 2) Patients allergic to corticosteroids, 3) Rectal CD or active fistulae, 4) Septic/infectious complications, 5) Perforations, 6) Previous ileostomy, pouch procedure, colostomy or ileal resection $>100 \mathrm{~cm}, 7$ ) Requirement for immediate surgery
Group 1: CIR budesonide (Entocort) 6 mg once daily for $16-22$ weeks $(n=60)$

Group 2: Placebo for $16-22$ weeks
1) Successful weaning and discontinuation of systemic corticosteroids without relapse (defined as CDAI $>200$ with an increase of 60 points from baseline)
2) Quality of life measured by IBDQ
3) Adverse events

\section{Notes}

\section{Risk of bias}

\begin{tabular}{lll}
\hline Bias & Authors' judgement & Support for judgement \\
\hline $\begin{array}{l}\text { Random sequence genera- } \\
\text { tion (selection bias) }\end{array}$ & Low risk & Randomization was completed in blocks, separately by centre \\
\hline $\begin{array}{l}\text { Allocation concealment } \\
\text { (selection bias) }\end{array}$ & Low risk & Sealed, opaque envelopes were used to assign treatment \\
\hline $\begin{array}{l}\text { Blinding (performance } \\
\text { bias and detection bias) } \\
\text { All outcomes }\end{array}$ & Low risk & Described as double blind \\
& $\begin{array}{l}\text { Appearance of placebo was identical to that of the study mediation } \\
\text { Blinding of outcome assessors was not described; however, the primary out- } \\
\text { come (based on the CDAl) is predominately based on patient reports (diary) } \\
\text { and is consequently at low risk of bias. }\end{array}$ \\
\hline
\end{tabular}

\begin{tabular}{lll}
$\begin{array}{l}\text { Incomplete outcome data } \\
\text { (attrition bias) } \\
\text { All outcomes }\end{array}$ & Low risk & Withdrawals were similar across groups \\
\hline $\begin{array}{l}\text { Selective reporting (re- } \\
\text { porting bias) }\end{array}$ & Low risk & All key outcomes included \\
\hline Other bias & Low risk & No additional sources of bias were identified \\
\hline
\end{tabular}

\section{de Jong 2007}

\begin{tabular}{ll}
\hline Methods & Randomized, double-blind, parallel group, multicenter trial \\
\hline Participants & Patients 18-75 years old with CD confined to ileum or colon in remission for 3-18 months (N = 157) \\
METHOD OF INDUCTION OF REMISSION: Any, except no small bowel resections $>80 \mathrm{~cm}$ within 6 \\
months of enrollment (remission defined as CDAI < 150) \\
EXCLUSION CRITERIA: 1 ) Rectal or perianal disease, 2) Bowel surgery within 6 months of enrollment, 3) \\
History of small bowel resections $>80 \mathrm{~cm}, 4)$ Disease locations proximal to ileum, 5) Severe hepatic/re- \\
nal disease, 6 ) Contraindication to corticosteroids, 7 ) Need for parenteral nutrition, 8) Presence of ac- \\
tive infection, 9) Pregnancy or inadequate use of contraception
\end{tabular}


de Jong 2007 (Continued)

Group 2: $\mathrm{pH}$-modified release budesonide (Budenofalk) $9 \mathrm{mg}$ once daily for 52 weeks ( $\mathrm{n}=81$ )
1) Relapse of disease (defined as CDAI > 150 and an increase of at least 60 points from baseline)

2) Time to relapse

3) Adverse events

Notes

\section{Risk of bias}

\begin{tabular}{lll}
\hline Bias & Authors' judgement & Support for judgement \\
\hline $\begin{array}{l}\text { Random sequence genera- } \\
\text { tion (selection bias) }\end{array}$ & Low risk & Patients were randomized using a computer-generated list \\
\hline $\begin{array}{l}\text { Allocation concealment } \\
\text { (selection bias) }\end{array}$ & Low risk & Sealed, opaque envelopes were used to assign treatment \\
\hline $\begin{array}{l}\text { Blinding (performance } \\
\text { bias and detection bias) } \\
\text { All outcomes }\end{array}$ & Low risk & Described as double blind \\
& $\begin{array}{l}\text { Appearance of placebo was identical to that of the study mediation } \\
\text { Blinding of outcome assessors was not described; however, the primary out- } \\
\text { come (based on the CDAl) is predominately based on patient reports (diary) } \\
\text { and is consequently at low risk of bias }\end{array}$
\end{tabular}

\begin{tabular}{lll}
\hline $\begin{array}{l}\text { Incomplete outcome data } \\
\text { (attrition bias) } \\
\text { All outcomes }\end{array}$ & Low risk & Withdrawals were similar across groups \\
\hline $\begin{array}{l}\text { Selective reporting (re- } \\
\text { porting bias) }\end{array}$ & Low risk & All key outcomes included \\
\hline Other bias & Low risk & No additional sources of bias were identified \\
\hline
\end{tabular}

\section{Ewe 1999}

\begin{tabular}{ll}
\hline Methods & Randomized, double-blind, placebo-controlled, multicenter trial \\
\hline Participants & $\begin{array}{l}\text { Patients with ileal, ileo-colonic or colonic CD ( } \mathrm{N}=83) \\
\text { METHOD OF INDUCTION OF REMISSION: 'Curative' surgical resection, without visible disease at resec- } \\
\text { tion margins and had an anastomosis accessible to colonoscopy } \\
\text { EXCLUSION CRITERIA: None listed, but five patients excluded due to lack of compliance, intraoperative } \\
\text { ileostomy, or error in diagnosis }\end{array}$ \\
\hline Interventions & $\begin{array}{l}\text { Group 1: } \mathrm{pH} \text {-modified release budesonide (Budenofalk) } 1 \mathrm{mg} \text { three times daily (3 mg/day) for } 12 \\
\text { months }(\mathrm{n}=43)\end{array}$ \\
Group 2: Placebo for 12 months $(\mathrm{n}=40)$
\end{tabular}
Outcomes
1) Recurrence of $C D$ based on endoscopic findings
2) A rise in CDAl from 60 up to 200 from the first follow-up or a CDAI > 200 and signs or symptoms char- acteristic of $C D$ were taken as recurrence if colonoscopy was refused
2) Histology scores 
Ewe 1999 (Continued)
3) CDAI
4) Global judgement of well-being
5) Time to relapse

\section{Notes}

\section{Risk of bias}

\begin{tabular}{lll}
\hline Bias & Authors' judgement & Support for judgement \\
\hline $\begin{array}{l}\text { Random sequence genera- } \\
\text { tion (selection bias) }\end{array}$ & Low risk & Patients were randomized using a computer-generated list \\
\hline $\begin{array}{l}\text { Allocation concealment } \\
\text { (selection bias) }\end{array}$ & Unclear risk & Allocation concealment is not discussed \\
\hline $\begin{array}{l}\text { Blinding (performance } \\
\text { bias and detection bias) } \\
\text { All outcomes }\end{array}$ & Low risk & Described as double blind \\
& $\begin{array}{l}\text { Appearance of placebo was identical to that of the study mediation } \\
\text { Blinding of outcome assessors was not described; however, the primary out- } \\
\text { come (based on the CDAl) is predominately based on patient reports (diary) } \\
\text { and is consequently at low risk of bias }\end{array}$ \\
\hline
\end{tabular}

\begin{tabular}{|c|c|c|}
\hline $\begin{array}{l}\text { Incomplete outcome data } \\
\text { (attrition bias) }\end{array}$ & Low risk & Withdrawals were similar across groups \\
\hline
\end{tabular}

All outcomes

Selective reporting (re- Low risk All key outcomes were included
porting bias)

Other bias Low risk No additional sources of bias were identified

Ferguson 1998

Methods Randomized, double-blind, placebo-controlled, multicenter study with three parallel groups

Participants Patients 18-65 years old with CD limited to the ileal or ileocecal region or ascending colon, in clinical remission defined by a $\mathrm{CDAI} \leq 150(\mathrm{~N}=75)$

METHOD OF INDUCTION OF REMISSION: 12-week course of budesonide in a clinical trial

EXCLUSION CRITERIA: 1) Ileostomy or previous small bowel resection $>100 \mathrm{~cm}, 2$ ) Pregnant or breastfeeding, 3) History of drug/alcohol abuse, 4) Active infection, 5) Active fistulae, 6) Rectal inflammation, 7) Hyperglycemia, 8) Significant hepatic/renal/cardiovascular disease, 9) Significant mental abnormality, 10) Any other steroid therapy, cholestyramine, azathioprine, 6-mercaptopurine, methotrexate, cyclosporine, metronidazole, tinidazole, sulfasalazine, other aminosalicylates, H2-blockers, proton pump inhibitors or parenteral, enteral or polymeric nutrition

Group 1: CIR budesonide (Entocort) $3 \mathrm{mg}$ twice daily $(6 \mathrm{mg} /$ day) for 12 months $(\mathrm{n}=22)$
Group 2: CIR budesonide (Entocort) 3 mg once daily for 12 months $(n=26)$
Group 3: Placebo for 12 months $(n=27)$

Outcomes
1) Proportion of patients with disease in remission defined as CDAI $<150$ at specific time points
2) Time to relapse of disease (defined as CDAI > 150 and an increase of at least 60 points from baseline) 
Ferguson 1998 (Continued)
3) CDAl changes
4) Adverse events
5) Baseline plasma cortisol
6) ACTH test

\begin{tabular}{lll}
\hline Notes & Additional unpublished data obtained from study sponsor \\
\hline Risk of bias & & \\
\hline Bias & Authors' judgement & Support for judgement \\
\hline $\begin{array}{l}\text { Random sequence genera- } \\
\text { tion (selection bias) }\end{array}$ & Low risk & Randomization was completed in blocks \\
\hline $\begin{array}{l}\text { Allocation concealment } \\
\text { (selection bias) }\end{array}$ & Low risk & Sealed, opaque envelopes were used to assign treatment \\
\hline $\begin{array}{l}\text { Blinding (performance } \\
\text { bias and detection bias) } \\
\text { All outcomes }\end{array}$ & Low risk & $\begin{array}{l}\text { Described as double blind } \\
\text { Appearance of placebo was identical to that of the study mediation }\end{array}$ \\
& $\begin{array}{l}\text { Blinding of outcome assessors was not described; however, the primary out- } \\
\text { come (based on the CDAl) is predominately based on patient reports (diary) } \\
\text { and is consequently at low risk of bias }\end{array}$ \\
\hline
\end{tabular}

Incomplete outcome data Low risk $\quad$ Withdrawals were similar across groups
(attrition bias)

All outcomes

Selective reporting (re- Low risk All key outcomes were included

porting bias)

Other bias Low risk No additional sources of bias were identified

Greenberg 1996

\begin{tabular}{ll}
\hline Methods & Randomized, multicenter, placebo-controlled dose-finding study \\
\hline Participants & $\begin{array}{l}\text { Patients }>18 \text { years of age with CD restricted to the ileum and colon proximal to the hepatic flexure, in } \\
\text { clinical remission defined by a CDAI } \leq 150 \text { ( } \mathrm{N}=105)\end{array}$ \\
& METHOD OF INDUCTION OF REMISSION: 8 week course of budesonide or placebo in a clinical trial \\
& which assessed $15 \mathrm{mg}, 9 \mathrm{mg}, 3 \mathrm{mg}$ or placebo to induce remission \\
& $27 \%$ of patients received $9 \mathrm{mg}$ of budesonide for 8 weeks in an open-label study after withdrawal from \\
the induction trial & \\
& EXCLUSION CRITERIA: 1) Ileostomy or surgical bowel resection more extensive than that of the terminal \\
& ileum or right colon, 2) Diabetes mellitus, 3) Active infection, 4) Peptic ulcer disease, 5) Cancer, 6) Sig- \\
nificant cardiac or hepatic disease, 7) Pregnancy or breast-feeding
\end{tabular}

Interventions

Group 1: CIR budesonide (Entocort) $6 \mathrm{mg}$ once daily for 52 weeks $(n=36)$

Group 2: CIR budesonide (Entocort) $3 \mathrm{mg}$ once daily for 52 weeks $(n=33)$ 
Greenberg 1996 (Continued)

Group 3: Placebo for 52 weeks $(n=36)$

1) Proportion of patients with disease in remission defined as CDAI < 150 at specific time points
2) Time to relapse of disease (defined as CDAI > 150 and an increase of at least 60 points from baseline)
3) Quality of life using IBDQ
4) Change in serum C-reactive protein
5) Corticotrophin stimulation test (normal response defined as baseline plasma cortisol concentration
$>200 \mathrm{nmol} / \mathrm{L}$ and an increment above baseline of at least $200 \mathrm{nmol} / \mathrm{L}$ or an absolute value of more than
$500 \mathrm{nmol} / \mathrm{L}$ at 30 or 60 minutes)

Notes

Additional unpublished data obtained from study sponsor

\section{Risk of bias}

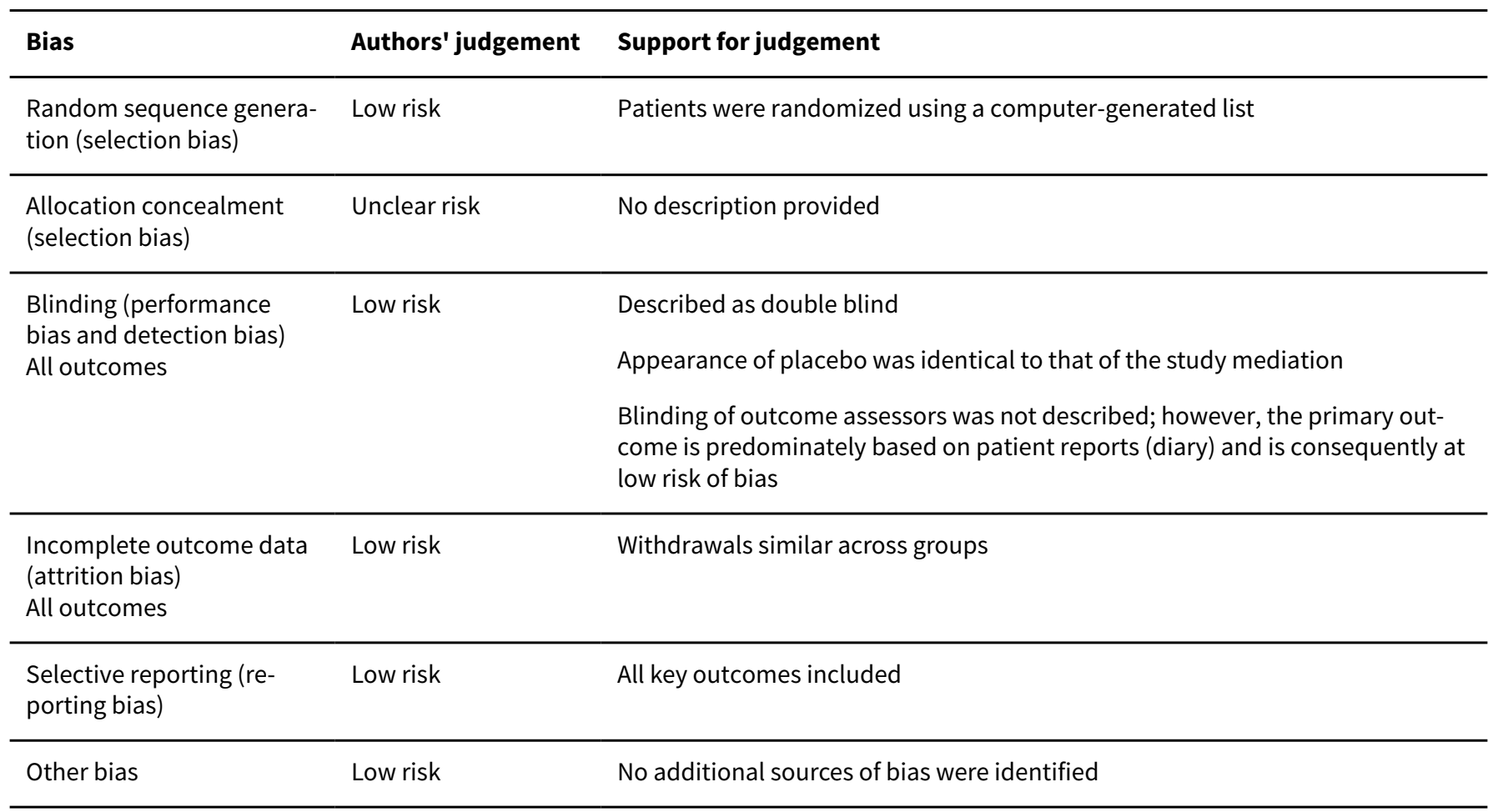

\section{Gross 1998}

\begin{tabular}{ll}
\hline Methods & Randomized, double-blind, placebo-controlled multicenter trial \\
\hline Participants & Patients 18-70 years old with active CD defined by a CDAI > 200 who then entered remission (defined by \\
CDAI $<150)$ following corticosteroid-treatment ( $=179)$ \\
METHOD OF INDUCTION OF REMISSION: Systemic corticosteroid therapy using the dosing regimen \\
from the European Cooperative Crohn's Disease study (Malchow 1984), consisting of methylpred- \\
nisolone 48 mg daily for one week, followed by a weekly wean \\
EXCLUSION CRITERIA: None listed, but no other method of treatment allowed
\end{tabular}

Interventions

Group 1: $\mathrm{pH}$-modified release budesonide (Budenofalk) $1 \mathrm{mg}$ three times daily ( $3 \mathrm{mg} /$ day) for 12 months $(n=84)$

Group 2: Placebo for 12 months $(\mathrm{n}=95)$ 
Gross 1998 (Continued)

Outcomes

1) Relapse of disease (defined as CDAI > 150 for more than two subsequent weeks, or a CDAI > 150 at the end of the study or at last documented visit)

2) Time to relapse

3) Adverse events

Notes

Study halted because it was shown to be statistically highly unlikely to prove hypothesis (superiority of budesonide compared with placebo for maintenance of remission)

Additional unpublished data obtained from study sponsor

\section{Risk of bias}

\begin{tabular}{lll}
\hline Bias & Authors' judgement & Support for judgement \\
\hline $\begin{array}{l}\text { Random sequence genera- } \\
\text { tion (selection bias) }\end{array}$ & Unclear risk & No description provided \\
\hline $\begin{array}{l}\text { Allocation concealment } \\
\text { (selection bias) }\end{array}$ & Unclear risk & No description provided \\
\hline $\begin{array}{l}\text { Blinding (performance } \\
\text { bias and detection bias) } \\
\text { All outcomes }\end{array}$ & Low risk & Described as double blind \\
& $\begin{array}{l}\text { Appearance of placebo was identical to that of the study mediation } \\
\text { Blinding of outcome assessors was not described; however, the primary out- } \\
\text { come (based on the CDAl) is predominately based on patient reports (diary) } \\
\text { and is consequently at low risk of bias }\end{array}$ \\
\hline
\end{tabular}

Incomplete outcome data Low risk

Withdrawals were similar across groups

(attrition bias)

All outcomes

Selective reporting (re- Low risk $\quad$ All key outcomes were included
porting bias)

\begin{tabular}{|c|c|c|}
\hline Other bias & Low risk & No additional sources of bias were identified \\
\hline
\end{tabular}

Hanauer 2005

\begin{tabular}{ll}
\hline Methods & Randomized, double-blind, placebo-controlled, multicenter trial \\
\hline Participants & Patients $>18$ years of age with CD restricted to the distal ileum or proximal colon, in clinical remission \\
defined by a CDAI $\leq 150(\mathrm{~N}=110)$ & METHOD OF INDUCTION OF REMISSION: 8 week course of treatment with budesonide $9 \mathrm{mg} / \mathrm{day}$ in a \\
& clinical trial \\
& EXCLUSION CRITERIA: 1) Previous ileostomy, colostomy, gastric surgery or ileal resection $>100 \mathrm{~cm}, 2)$ \\
& Active infection, 3) Peptic ulcer disease, 4) Cancer, 5) Uncontrolled diabetes, 6$)$ Significant hepatic, re- \\
& nal, cardiovascular, endocrinologic, neurologic or psychiatric disease, 7) Immunosuppression for 90 \\
& days prior to baseline induction study, 8) corticosteroids 14 days prior to baseline induction study, 9) \\
& Mesalamine or NSAIDs $>3$ consecutive days, 10) Magnesium-containing antacids, 11) Any anti-inflam- \\
& matory or immunomodulator drugs for CD (other than budesonide)
\end{tabular}

Interventions

Group 1: CIR budesonide (Entocort) 6 mg once daily for 52 weeks $(n=55)$

Group 2: Placebo for 52 weeks $(n=55)$ 
Hanauer 2005 (Continued)

Outcomes $\quad$ 1) Proportion of patients with disease in remission defined as CDAI $<150$ at specific time points

2) Time to relapse of disease (defined as CDAI > 150 and an increase of at least 60 points from baseline)

3) ACTH stimulation test (normal response defined as baseline plasma cortisol concentration $\geq 150$ $\mathrm{nmol} / \mathrm{L}$ and a concentration of $\geq 400 \mathrm{nmol} / \mathrm{L}$ or an increase of at least $200 \mathrm{nmol} / \mathrm{L}$ at 30 or 60 minutes)

Notes Additional unpublished data obtained from study sponsor

\section{Risk of bias}

\begin{tabular}{lll}
\hline Bias & Authors' judgement & Support for judgement \\
\hline $\begin{array}{l}\text { Random sequence genera- } \\
\text { tion (selection bias) }\end{array}$ & Low risk & Patients were randomized using a computer-generated list \\
\hline $\begin{array}{l}\text { Allocation concealment } \\
\text { (selection bias) }\end{array}$ & Unclear risk & No description provided \\
\hline $\begin{array}{l}\text { Blinding (performance } \\
\text { bias and detection bias) } \\
\text { All outcomes }\end{array}$ & Low risk & Described as double blind \\
& $\begin{array}{l}\text { Appearance of placebo was identical to that of the study mediation } \\
\text { Blinding of outcome assessors was not described; however, the primary out- } \\
\text { come (based on the CDAl) is predominately based on patient reports (diary) } \\
\text { and is consequently at low risk of bias }\end{array}$
\end{tabular}

\begin{tabular}{lll}
$\begin{array}{l}\text { Incomplete outcome data } \\
\text { (attrition bias) } \\
\text { All outcomes }\end{array}$ & Low risk & Withdrawals similar across groups \\
\hline $\begin{array}{l}\text { Selective reporting (re- } \\
\text { porting bias) }\end{array}$ & Low risk & All key outcomes were included \\
\hline Other bias & Low risk & No additional sources of bias were detected \\
\hline
\end{tabular}

\section{Hellers 1999}

\begin{tabular}{ll}
\hline Methods & Randomized, parallel-group, double-blind, placebo-controlled, multicenter trial \\
\hline Participants & $\begin{array}{l}\text { Patients scheduled for surgical resection of ileocolonic CD }(\mathrm{N}=130) \\
\text { METHOD OF INDUCTION OF REMISSION: Surgical resection of diseased area }\end{array}$ \\
& $\begin{array}{l}\text { EXCLUSION CRITERIA: } 1 \text { ) Previous ileal resection }>100 \mathrm{~cm}, 2) \text { Infectious complication such as abscess } \\
\text { or fistula, 3) Corticosteroids less than } 30 \text { days from surgery, 4) Any medication for treatment of CD (ex- } \\
\text { cept budesonide) }\end{array}$
\end{tabular}

Group 1: CIR budesonide (Entocort) 6 mg once daily for 52 weeks $(n=63)$
Group 2: Placebo for 52 weeks $(n=67)$
Outcomes
1) Proportion of patients with disease in remission defined as $C D A I<150$ at specific time points
2) Recurrence of disease defined by a score of 2 or higher on the Rutgeerts scale (Rutgeerts 1990)
3) CDAI score (note: baseline CDAI was taken 6 weeks after surgical resection to induce remission) 
Hellers 1999 (Continued)

4) ACTH stimulation test (normal response defined as baseline plasma cortisol concentration $\geq 150$ $\mathrm{nmol} / \mathrm{L}$ and a concentration of $\geq 400 \mathrm{nmol} / \mathrm{L}$ or an increase of at least $200 \mathrm{nmol} / \mathrm{L}$ at 30 or 60 minutes).

Notes

Additional unpublished data obtained from study sponsor

\section{Risk of bias}

\begin{tabular}{lll}
\hline Bias & Authors' judgement & Support for judgement \\
\hline $\begin{array}{l}\text { Random sequence genera- } \\
\text { tion (selection bias) }\end{array}$ & Unclear risk & No description provided \\
\hline $\begin{array}{l}\text { Allocation concealment } \\
\text { (selection bias) }\end{array}$ & Unclear risk & No description provided \\
\hline $\begin{array}{l}\text { Blinding (performance } \\
\text { bias and detection bias) } \\
\text { All outcomes }\end{array}$ & Unclear risk & $\begin{array}{l}\text { The study is described as double blind; however, no description is provided } \\
\text { with regard to the mechanisms to ensure the blinding of participants and out- } \\
\text { come assessors (endoscopists) }\end{array}$ \\
\hline $\begin{array}{l}\text { Incomplete outcome data } \\
\text { (attrition bias) } \\
\text { All outcomes }\end{array}$ & Low risk & Withdrawals similar across groups \\
\hline $\begin{array}{l}\text { Selective reporting (re- } \\
\text { porting bias) }\end{array}$ & Low risk & All key outcomes were included \\
\hline \begin{tabular}{l} 
Other bias \\
\hline
\end{tabular} & Low risk & No additional sources of bias were identified \\
\hline
\end{tabular}

Lofberg 1996

\begin{tabular}{ll}
\hline Methods & Randomized, double-blind, placebo-controlled, multicenter study with three parallel groups \\
\hline Participants & Patients $>18$ years of age with CD restricted to the terminal ileum or ileocecal region, in clinical remis- \\
& sion defined by a CDAI $\leq 150(\mathrm{~N}=90)$ \\
& METHOD OF INDUCTION OF REMISSION: 10 week course of either budesonide or prednisolone in a clin- \\
& ical trial \\
& EXCLUSION CRITERIA: 1) Septic complications, 2) Active inflammation of the rectum, 3) Peptic ulcer \\
disease, 4) Diabetes mellitus, 5) Hyperglycemia, 6) Significant hepatic, renal or cardiovascular disease, \\
7) Patients receiving total parenteral, enteric or polymeric nutrition, 8) lleostomy or previous small \\
bowel resection $>100 \mathrm{~cm}$
\end{tabular}

\begin{tabular}{ll}
\hline Interventions & Group 1: CIR budesonide (Entocort) 6 mg daily for 12 months $(n=32)$ \\
Group 2: CIR budesonide (Entocort) 3 mg daily for 12 months $(n=31)$ \\
Group 3: Placebo for 12 months $(n=27)$
\end{tabular}
Outcomes
1) Proportion of patients with disease in remission defined as $C D A I<150$ at specific time points
2) Time to relapse of disease (defined as CDAI > 150 and an increase of at least 60 points from baseline)
3) Adverse events
4) ACTH stimulation test (normal response defined as baseline plasma cortisol concentration $\geq 150$ $\mathrm{nmol} / \mathrm{L}$ and a concentration of $\geq 400 \mathrm{nmol} / \mathrm{L}$ or an increase of at least $200 \mathrm{nmol} / \mathrm{L}$ at 30 or 60 minutes) 
Lofberg 1996 (Continued)

Risk of bias

\begin{tabular}{lll}
\hline Bias & Authors' judgement & Support for judgement \\
\hline $\begin{array}{l}\text { Random sequence genera- } \\
\text { tion (selection bias) }\end{array}$ & Low risk & Patients were randomized in blocks at each centre \\
\hline $\begin{array}{l}\text { Allocation concealment } \\
\text { (selection bias) }\end{array}$ & Unclear risk & No description provided \\
\hline $\begin{array}{l}\text { Blinding (performance } \\
\text { bias and detection bias) } \\
\text { All outcomes }\end{array}$ & Low risk & Described as double blind \\
& $\begin{array}{l}\text { Appearance of placebo was identical to that of the study mediation } \\
\text { Blinding of outcome assessors was not described; however, the primary out- } \\
\text { come (based on the CDAl) is predominately based on patient reports (diary) } \\
\text { and is consequently at low risk of bias }\end{array}$ \\
\hline
\end{tabular}

Incomplete outcome data Low risk Withdrawals were similar across groups
(attrition bias)

All outcomes

Selective reporting (re- Low risk All key outcomes were included

porting bias)

Other bias Low risk No additional sources of bias were identified

Mantzaris 2003

\begin{tabular}{|c|c|}
\hline Methods & Randomized, investigator-blinded, controlled trial \\
\hline \multirow[t]{6}{*}{ Participants } & $\begin{array}{l}\text { Patients } 18-65 \text { years old with } \mathrm{CDAl} \leq 150 \text { who were steroid-dependent, defined as at least two courses } \\
\text { of oral or intravenous corticosteroids in the preceding } 12 \text { months with a relapse of disease prior to dis- } \\
\text { continuation }(N=57)\end{array}$ \\
\hline & Patients had disease limited to the ileum, ileocolonic region or proximal colon \\
\hline & $\begin{array}{l}\text { METHOD OF INDUCTION OF REMISSION: Prednisolone } 1 \mathrm{mg} / \mathrm{kg} \text { for at least } 4 \text { months prior to study with } \\
\text { the dose tapered by } 5 \mathrm{mg} / \text { week to the lowest dose possible to maintain remission effectively }\end{array}$ \\
\hline & $\begin{array}{l}\text { EXCLUSION CRITERIA: 1) Patients maintained on mesalamine, 2) Patients maintained on azathioprine } \\
\text { unless it had been withdrawn as a result of intolerance or side effects at least } 3 \text { months prior to trial en- } \\
\text { rollment, 3) Patients with left-sided colitis or perianal disease, 4) Fibrostenotic or fistulizing disease, 5) }\end{array}$ \\
\hline & Prior intestinal resection for $\mathrm{CD}, 6$ ) Pregnancy or breast-feeding, 7) Allergy to steroids or mesalamine, 8) \\
\hline & Regular use of NSAIDs or antibiotics, 9) Diabetes mellitus, 10) Chronic renal, hepatic or heart failure \\
\hline
\end{tabular}

Interventions

Group 1: CIR budesonide (Entocort) $6 \mathrm{mg}$ daily for 1 year $(\mathrm{n}=29)$

Group 2: $\mathrm{pH}$-dependent release mesalamine (Salofalk) 1 gram three times daily $(3 \mathrm{~g} /$ day) for 1 year $(\mathrm{n}=$ 28)
Outcomes
1) Relapse of disease (defined as CDAI > 150 and an increase of at least 100 points from baseline)
2) Time to relapse
3) Quality of life using IBDQ
4) Adverse events 
Mantzaris 2003 (Continued)

Notes

\section{Risk of bias}

\begin{tabular}{lll}
\hline Bias & Authors' judgement & Support for judgement \\
\hline $\begin{array}{l}\text { Random sequence genera- } \\
\text { tion (selection bias) }\end{array}$ & Unclear risk & No description provided \\
\hline $\begin{array}{l}\text { Allocation concealment } \\
\text { (selection bias) }\end{array}$ & Unclear risk & No description provided \\
\hline $\begin{array}{l}\text { Blinding (performance } \\
\text { bias and detection bias) } \\
\text { All outcomes }\end{array}$ & High risk & Study participants were not blinded \\
& & $\begin{array}{l}\text { Investigators were blinded but mechanisms to ensure blinding were not de- } \\
\text { scribed }\end{array}$ \\
\hline
\end{tabular}

Incomplete outcome data Low risk $\quad$ Withdrawals were similar across groups
(attrition bias)

All outcomes

Selective reporting (re- Low risk All key outcomes were included

porting bias)

Other bias Low risk No additional sources of bias were identified

Mantzaris 2009

\begin{tabular}{ll}
\hline Methods & Randomized endoscopist- and pathologist-blinded single-centre trial with 2 parallel groups \\
\hline Participants & $\begin{array}{l}\text { Patients } 18-67 \text { years old with inflammatory steroid-dependent Crohn's proximal colitis or ileocolitis in } \\
\text { remission }(\mathrm{CDAl}<150)\end{array}$ \\
& $\begin{array}{l}\text { Patients with } \geq 1 \text { flare within the past } 6-12 \text { months that had responded to steroids but experienced a re- } \\
\text { lapse while tapering or shortly following the withdrawal of steroids were considered to be steroid de- } \\
\text { pendent }(\mathrm{N}=77)\end{array}$
\end{tabular}

\section{METHOD OF INDUCTION OF REMISSION: Steroids}

EXCLUSION CRITERIA: 1) Prior exposure to infliximab or azathioprine for more than one month, 2) Leftsided colitis, 3) Fibrostenotic or fistulizing CD, 4) Prior resection, 5) Prednisone more than $30 \mathrm{mg}$ per day, 6) History of diabetes mellitus, tuberculosis, hepatitis B or C, human immunodeficiency virus, 7) Regular use of nonsteroidal anti-inflammatory drugs, 8) Existing or intended pregnancy or lactation, 9) Peptic ulcer disease, 10) Chronic renal, hepatic, or heart failure

Interventions Group 1: CIR Budesonide (Budecol; AstraZeneca A\&D, Lund, Sweden) 6-9 mg once daily for one year $(\mathrm{n}=$ 39)

Group 2: Azathioprine $2.0-2.5 \mathrm{mg} / \mathrm{kg}$ daily for one year $(\mathrm{n}=38)$
Outcomes
1) Rate of mucosal healing based on the Crohn's Disease Endoscopic Index of Severity (CDEIS; Mary 1989) and histologic remission based on the D'Haens score (D'Haens 1998)
2) Annual relapse rate
3) Time in remission
4) Time to discontinuation of study medication 
Mantzaris 2009 (Continued)

5) Changes in CDAI scores and health-related quality of life

Notes

\section{Risk of bias}

\begin{tabular}{|c|c|c|}
\hline Bias & Authors' judgement & Support for judgement \\
\hline $\begin{array}{l}\text { Random sequence genera- } \\
\text { tion (selection bias) }\end{array}$ & Low risk & Patients were randomized using a computer-generated list \\
\hline \multirow[t]{2}{*}{$\begin{array}{l}\text { Allocation concealment } \\
\text { (selection bias) }\end{array}$} & High risk & $\begin{array}{l}\text { Patients were not aware that they were participating in a randomized trial and } \\
\text { separate consent forms were used for each trial arm }\end{array}$ \\
\hline & & $\begin{array}{l}\text { Selective enrolment of participants based on the results of randomization may } \\
\text { have resulted in selection bias }\end{array}$ \\
\hline \multirow{2}{*}{$\begin{array}{l}\text { Blinding (performance } \\
\text { bias and detection bias) } \\
\text { All outcomes }\end{array}$} & High risk & $\begin{array}{l}\text { Participants were not blinded as they were not aware of the other treatment } \\
\text { arm in the study }\end{array}$ \\
\hline & & The endoscopist and pathologist were blinded to study group \\
\hline $\begin{array}{l}\text { Incomplete outcome data } \\
\text { (attrition bias) } \\
\text { All outcomes }\end{array}$ & Low risk & Withdrawals were similar across groups \\
\hline $\begin{array}{l}\text { Selective reporting (re- } \\
\text { porting bias) }\end{array}$ & Low risk & All key outcomes were included \\
\hline Other bias & Low risk & No additional sources of bias were identified \\
\hline
\end{tabular}

Schoon 2005

\begin{tabular}{ll}
\hline Methods & Randomized, controlled, open, multicenter trial \\
\hline Participants & Patients $20-70$ years old with CD affecting the distal ileum, ileocecal region or ascending colon, in clini- \\
cal remission defined by a CDAI $\leq 200(\mathrm{~N}=90)$ & \\
METHOD OF INDUCTION OF REMISSION: Prednisolone or prednisone $7-20 \mathrm{mg} / \mathrm{day}$ (at enrollment and \\
for at least 4 of the preceding 6 months) \\
EXCLUSION CRITERIA: 1$)$ CD proximal to the ileum, 2) Active CD in the rectum, 3) Previous gastric \\
surgery, 4) Resection of $>100 \mathrm{~cm}$ of small bowel, 5) Resection of tissues distal to mid-transverse colon, \\
6) Complicated CD (abscess, obstruction or perforation), 7) Hypersensitivity to corticosteroids, 8) Im- \\
munosuppressants within the past 3 months, 9) Hormone replacement therapy, bisphosphonates, an- \\
drogens, or anabolic steroids
\end{tabular}

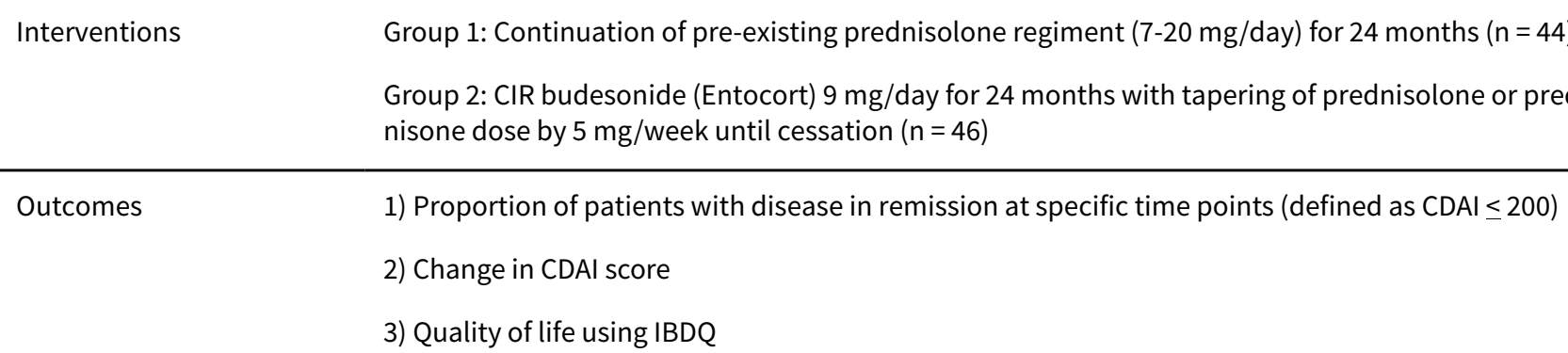


Schoon 2005 (Continued)

4) ACTH stimulation test (normal response defined as baseline plasma cortisol concentration $\geq 150$ $\mathrm{nmol} / \mathrm{L}$ and a concentration of $\geq 400 \mathrm{nmol} / \mathrm{L}$ or an increase of at least $200 \mathrm{nmol} / \mathrm{L}$ prior to 60 minutes),

5) Bone mineral density using DXA

Notes Main reference aimed at discussing bone mineral density results and not other outcomes

Additional unpublished data obtained from study authors

\section{Risk of bias}

\begin{tabular}{lll}
\hline Bias & Authors' judgement & Support for judgement \\
\hline $\begin{array}{l}\text { Random sequence genera- } \\
\text { tion (selection bias) }\end{array}$ & Low risk & Patients were randomized using a computer-generated list \\
\hline $\begin{array}{l}\text { Allocation concealment } \\
\text { (selection bias) }\end{array}$ & Unclear risk & No description provided \\
\hline $\begin{array}{l}\text { Blinding (performance } \\
\text { bias and detection bias) } \\
\text { All outcomes }\end{array}$ & High risk & Study was not blinded to allow for adjustments in dose throughout the trial \\
\hline $\begin{array}{l}\text { Incomplete outcome data } \\
\text { (attrition bias) }\end{array}$ & Low risk & Withdrawals were similar across all groups \\
\hline $\begin{array}{l}\text { All outcomes } \\
\text { pelective reporting (re- }\end{array}$ & Low risk & All key outcomes were included \\
\hline $\begin{array}{l}\text { Other bias } \\
\text { The aim of this study was to compare bone mineral density across the two }\end{array}$ & treatments \\
\hline
\end{tabular}

CDAI = Crohn's Disease Activity Index

$\mathrm{CIR}=$ controlled-ileal release

$\mathrm{IBDQ}=$ Inflammatory Bowel Disease Questionnaire

$C D=$ Crohn's disease

$\mathrm{ACTH}=$ Adrenocorticotropic hormone

DXA = Dual-energy X-ray absorptiometry

Characteristics of excluded studies [ordered by study ID]

\begin{tabular}{ll}
\hline Study & Reason for exclusion \\
\hline Dignass 2014 & Induction trial \\
\hline Ecker 2003 & Treatment group only, no control group \\
& Purpose of the study was to evaluate the effect of budesonide on ileostomy output \\
\hline Green 2001 & Fixed versus flexible dose budesonide \\
\hline Levine 2009 & No non-budesonide control group was included \\
\hline Pohl 1997 & Induction trial \\
\hline Rudeview of two included clinical trials (Greenberg 1996; Lofberg 1996)
\end{tabular}




\begin{tabular}{ll}
\hline Study & Reason for exclusion \\
\hline Sandborn 2005 & Systematic review and meta-analysis of previously published controlled clinical trials \\
\hline Suzuki 2013 & Induction trial \\
\hline Tromm 2011 & Induction trial \\
\hline
\end{tabular}

\section{Characteristics of ongoing studies [ordered by study ID]}

\begin{tabular}{ll}
\hline NCT01453946 & Safety and maintenance study of entocort for children with Crohn's disease \\
\hline Methods & Open-label, single group study \\
\hline Participants & Children aged 5-17 years with Crohn's disease in remission (PCDAl $\leq 10)$ \\
\hline Interventions & Budesonide 6 mg daily \\
\hline Outcomes & $\begin{array}{l}\text { Safety profile, in terms of adverse events, clinical laboratory evaluations, physical examinations, } \\
\text { including evaluation of glucocorticosteroid-related side effects, hypothalamic-pituitary-adrenal } \\
\text { axis, and vital signs }\end{array}$ \\
\hline Starting date & December 2011 \\
\hline Contact information & Not provided \\
\hline Notes & Study was completed in February 2014 \\
Results are not yet available
\end{tabular}

PCDAI = Pediatric Crohn's disease activity index

\section{DATA AND ANALYSES}

\section{Comparison 1. Budesonide 6 mg vs placebo}

\begin{tabular}{lllll}
\hline Outcome or subgroup title & No. of studies & $\begin{array}{l}\text { No. of partici- } \\
\text { pants }\end{array}$ & Statistical method & Effect size \\
\hline 1 Maintenance of clinical remission & 6 & & $\begin{array}{l}\text { Risk Ratio (M-H, Random, 95\% } \\
\mathrm{Cl})\end{array}$ & Subtotals only \\
\hline 1.13 months & 6 & 540 & $\begin{array}{l}\text { Risk Ratio (M-H, Random, 95\% } \\
\mathrm{Cl})\end{array}$ & $1.25[1.00,1.58]$ \\
\hline 1.26 months & 5 & 420 & $\begin{array}{l}\text { Risk Ratio (M-H, Random, 95\% } \\
\text { Cl) }\end{array}$ & $1.15[0.95,1.39]$ \\
\hline 1.312 months & 5 & 420 & $\begin{array}{l}\text { Risk Ratio (M-H, Random, 95\% } \\
\text { Cl) }\end{array}$ & $1.13[0.94,1.35]$ \\
\hline
\end{tabular}




\begin{tabular}{|c|c|c|c|c|}
\hline Outcome or subgroup title & No. of studies & $\begin{array}{l}\text { No. of partici- } \\
\text { pants }\end{array}$ & Statistical method & Effect size \\
\hline $\begin{array}{l}\text { 1.4 Subgroup (Budesonide Induc- } \\
\text { tion) - } 3 \text { months }\end{array}$ & 4 & 290 & $\begin{array}{l}\text { Risk Ratio (M-H, Random, 95\% } \\
\mathrm{Cl} \text { ) }\end{array}$ & $1.23[1.00,1.52]$ \\
\hline $\begin{array}{l}1.5 \text { Subgroup (Medical Induction) - } \\
3 \text { months }\end{array}$ & 5 & 410 & $\begin{array}{l}\text { Risk Ratio (M-H, Random, 95\% } \\
\mathrm{Cl})\end{array}$ & $1.36[1.11,1.68]$ \\
\hline $\begin{array}{l}1.6 \text { Subgroup (Medical Induction) - } \\
12 \text { months }\end{array}$ & 4 & 290 & $\begin{array}{l}\text { Risk Ratio (M-H, Random, 95\% } \\
\mathrm{Cl})\end{array}$ & $1.29[1.00,1.67]$ \\
\hline 2 Change in CDAl from baseline & 5 & & $\begin{array}{l}\text { Mean Difference (IV, Random, } \\
95 \% \mathrm{CI})\end{array}$ & Subtotals only \\
\hline $\begin{array}{l}\text { 2.1 Change after } 3 \text { months of treat- } \\
\text { ment }\end{array}$ & 5 & 420 & $\begin{array}{l}\text { Mean Difference (IV, Random, } \\
95 \% \mathrm{CI})\end{array}$ & $-15.06[-36.04,5.93]$ \\
\hline $\begin{array}{l}2.2 \text { Change after } 6 \text { months of treat- } \\
\text { ment }\end{array}$ & 5 & 420 & $\begin{array}{l}\text { Mean Difference (IV, Random, } \\
95 \% \mathrm{CI})\end{array}$ & $\begin{array}{l}-24.30[-46.31 \\
-2.29]\end{array}$ \\
\hline $\begin{array}{l}2.3 \text { Change after } 12 \text { months of } \\
\text { treatment }\end{array}$ & 5 & 420 & $\begin{array}{l}\text { Mean Difference (IV, Random, } \\
95 \% \mathrm{CI})\end{array}$ & $\begin{array}{l}-23.49[-46.65 \\
-0.32]\end{array}$ \\
\hline $\begin{array}{l}\text { 2.4 Subgroup (Medical Induction) - } \\
3 \text { months }\end{array}$ & 4 & 290 & $\begin{array}{l}\text { Mean Difference (IV, Random, } \\
95 \% \mathrm{CI} \text { ) }\end{array}$ & $\begin{array}{l}-25.27[-43.61 \\
-6.94]\end{array}$ \\
\hline $\begin{array}{l}2.5 \text { Subgroup (Medical Induction) - } \\
6 \text { months }\end{array}$ & 4 & 290 & $\begin{array}{l}\text { Mean Difference (IV, Random, } \\
95 \% \mathrm{CI})\end{array}$ & $\begin{array}{l}-36.56[-55.50 \\
-17.62]\end{array}$ \\
\hline $\begin{array}{l}\text { 2.6 Subgroup (Medical Induction) - } \\
12 \text { months }\end{array}$ & 4 & 290 & $\begin{array}{l}\text { Mean Difference (IV, Random, } \\
95 \% \mathrm{CI})\end{array}$ & $\begin{array}{l}-34.76[-55.42 \\
-14.10]\end{array}$ \\
\hline 3 Mean Time to Relapse (Days) & 4 & 171 & $\begin{array}{l}\text { Mean Difference (IV, Random, } \\
95 \% \mathrm{CI})\end{array}$ & $\begin{array}{l}59.93[19.02 \\
100.84]\end{array}$ \\
\hline $\begin{array}{l}4 \text { Withdrawals due to Treatment } \\
\text { Failure }\end{array}$ & 6 & 538 & $\begin{array}{l}\text { Risk Ratio (M-H, Random, 95\% } \\
\mathrm{CI})\end{array}$ & $0.75[0.55,1.03]$ \\
\hline $\begin{array}{l}5 \text { Proportion of Patients with } \\
\text { Treatment-Related Adverse Events } \\
\text { at } 12 \text { Months }\end{array}$ & 5 & 419 & $\begin{array}{l}\text { Risk Ratio (M-H, Random, 95\% } \\
\mathrm{Cl})\end{array}$ & $1.51[0.90,2.52]$ \\
\hline $\begin{array}{l}6 \text { Withdrawals due to Adverse } \\
\text { Events }\end{array}$ & 5 & 466 & $\begin{array}{l}\text { Risk Ratio (M-H, Random, 95\% } \\
\mathrm{Cl})\end{array}$ & $1.08[0.60,1.95]$ \\
\hline 7 Abnormal ACTH Stimulation Test & 4 & 295 & $\begin{array}{l}\text { Risk Ratio (M-H, Random, 95\% } \\
\text { Cl) }\end{array}$ & $2.72[1.62,4.58]$ \\
\hline
\end{tabular}


Analysis 1.1. Comparison 1 Budesonide $6 \mathrm{mg}$ vs placebo, Outcome 1 Maintenance of clinical remission.

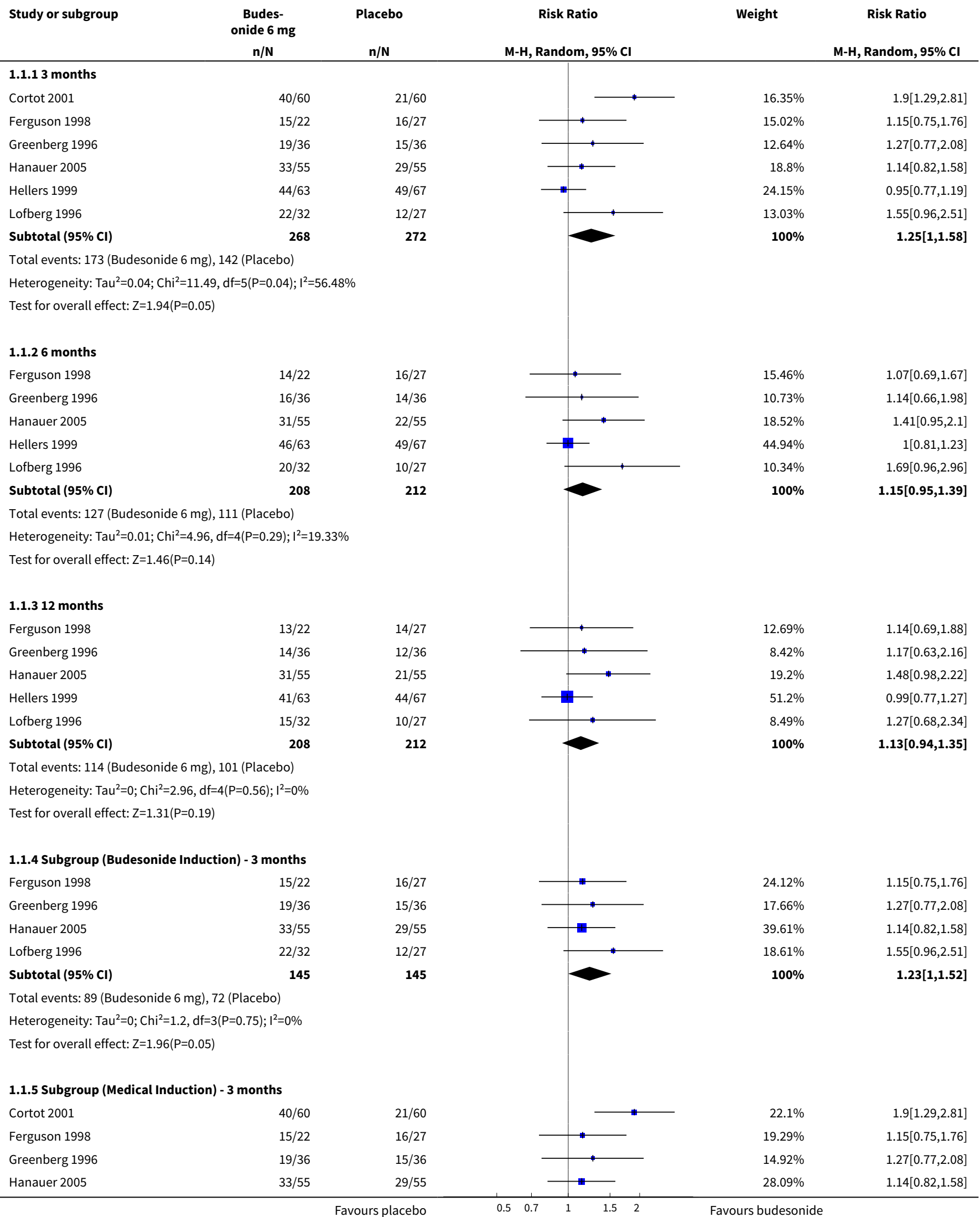




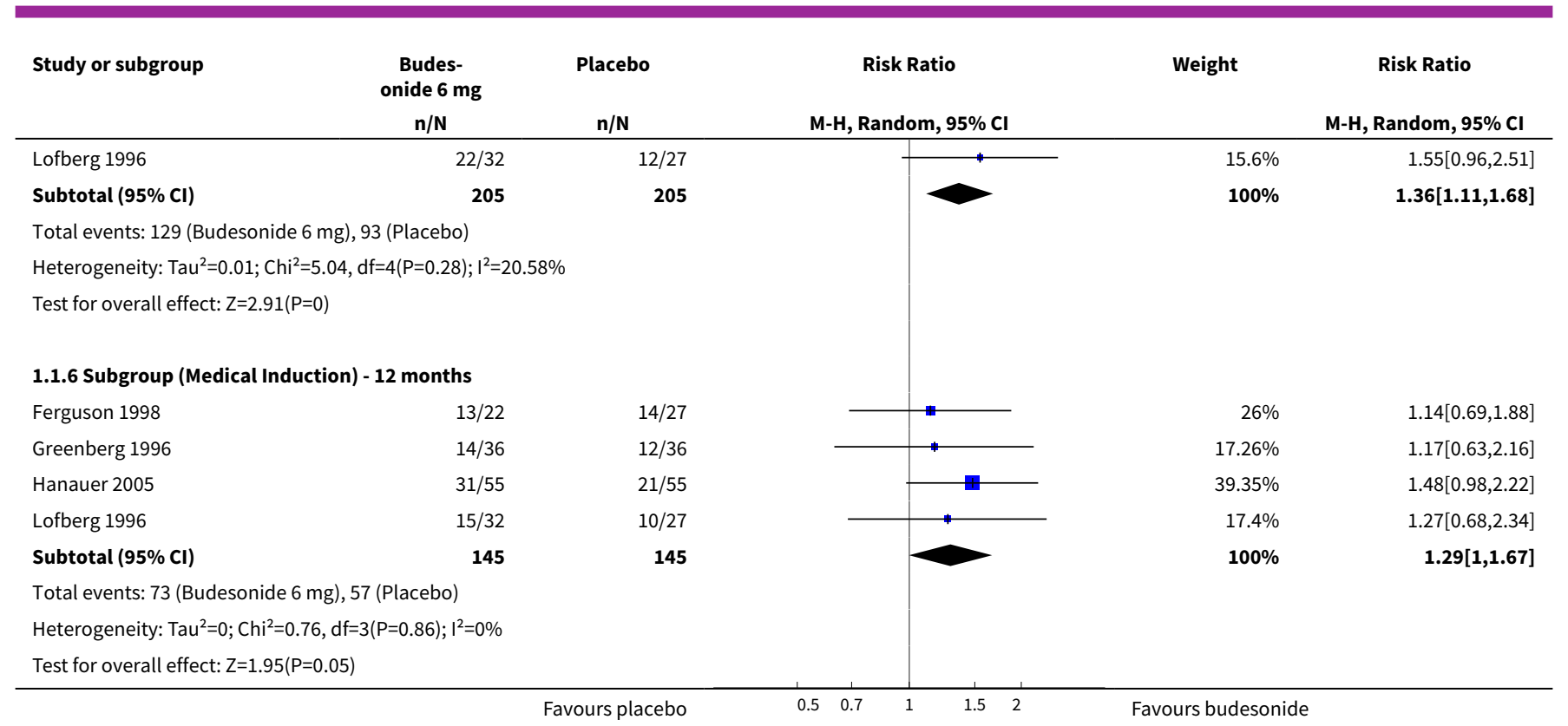

\section{Analysis 1.2. Comparison 1 Budesonide $6 \mathrm{mg}$ vs placebo, Outcome 2 Change in CDAl from baseline.}

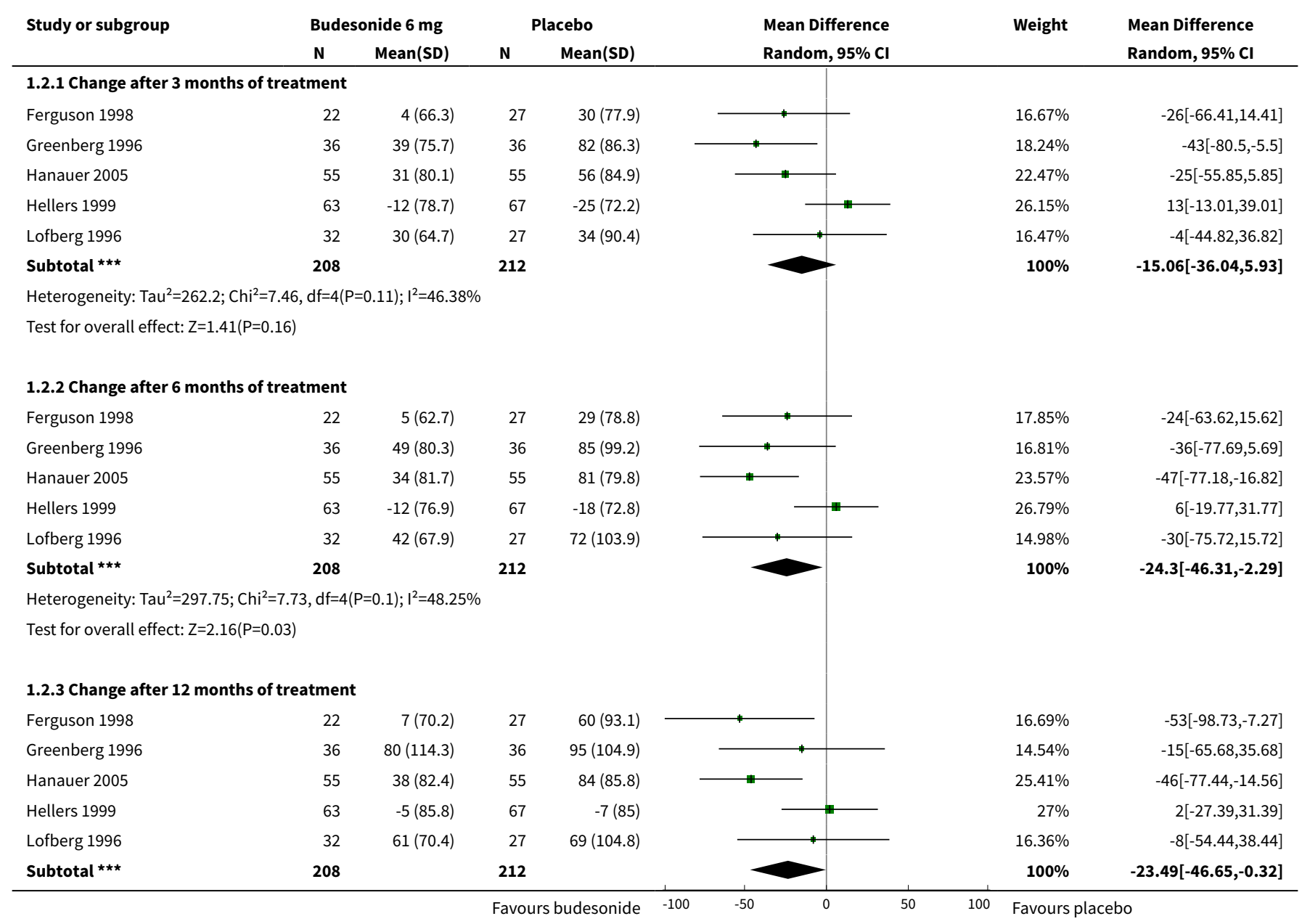




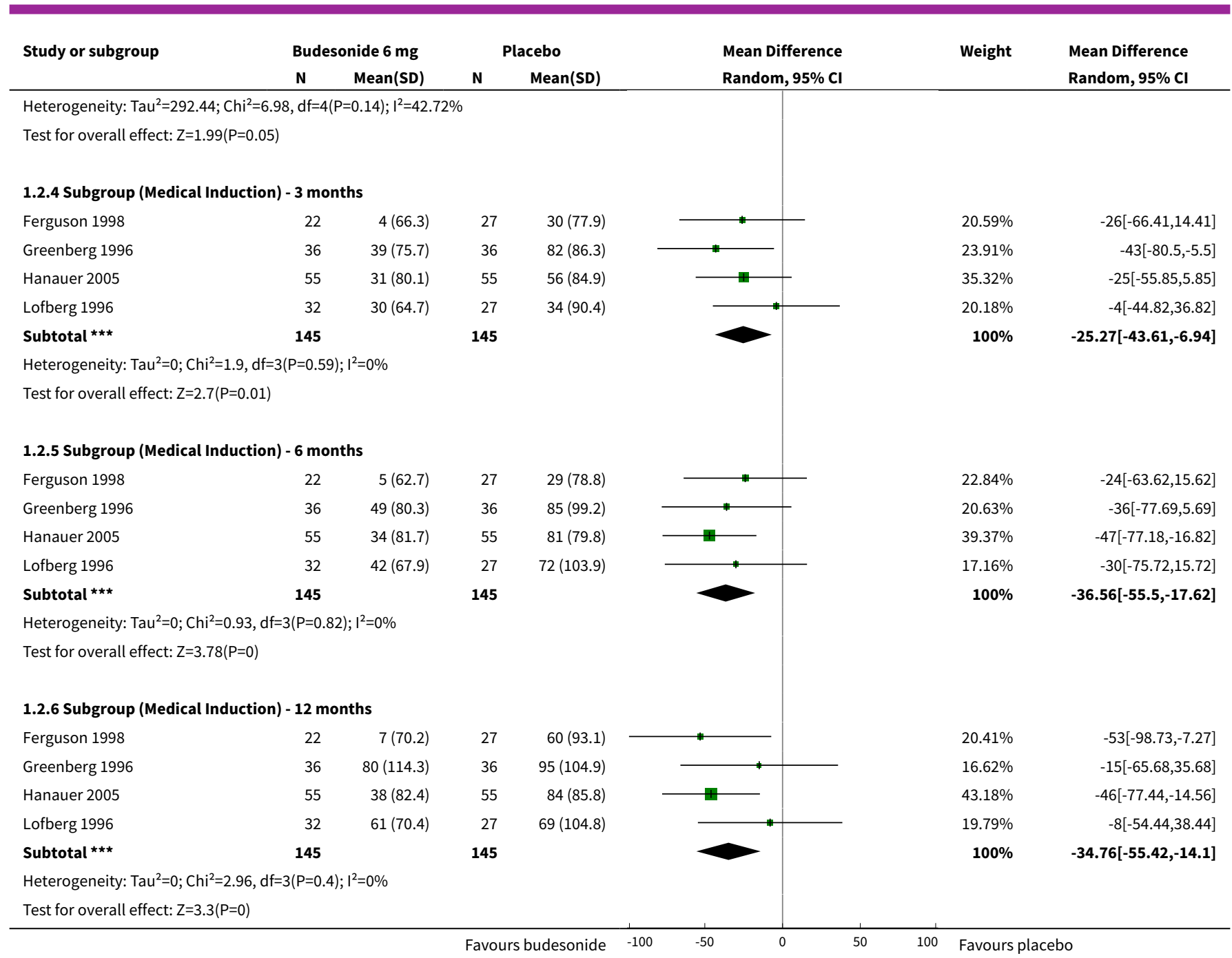

Analysis 1.3. Comparison 1 Budesonide $6 \mathrm{mg}$ vs placebo, Outcome 3 Mean Time to Relapse (Days).

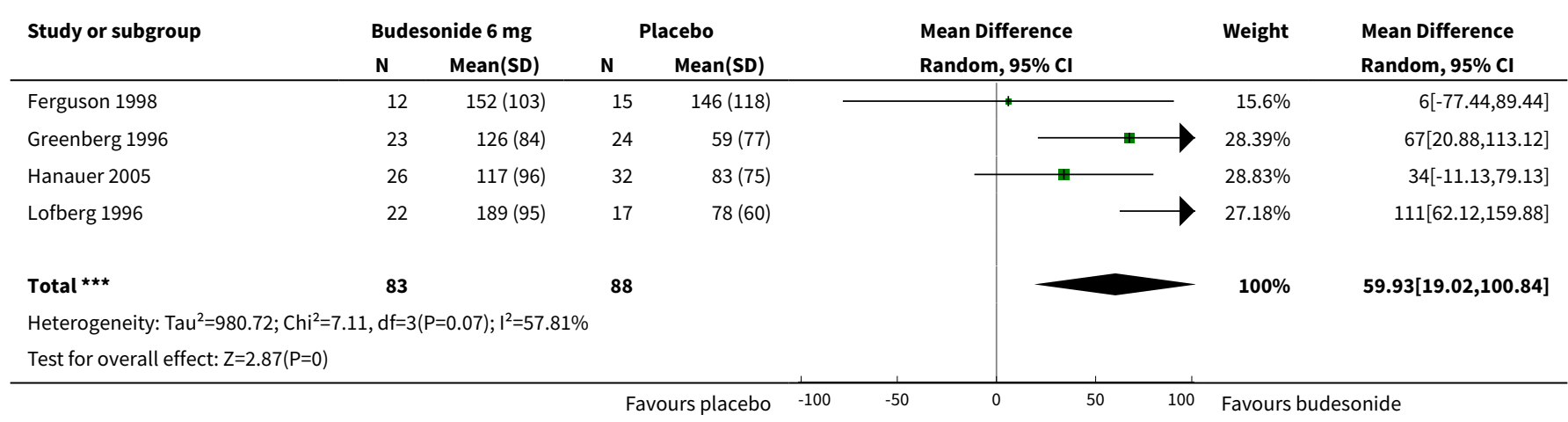


Analysis 1.4. Comparison 1 Budesonide 6 mg vs placebo, Outcome 4 Withdrawals due to Treatment Failure.

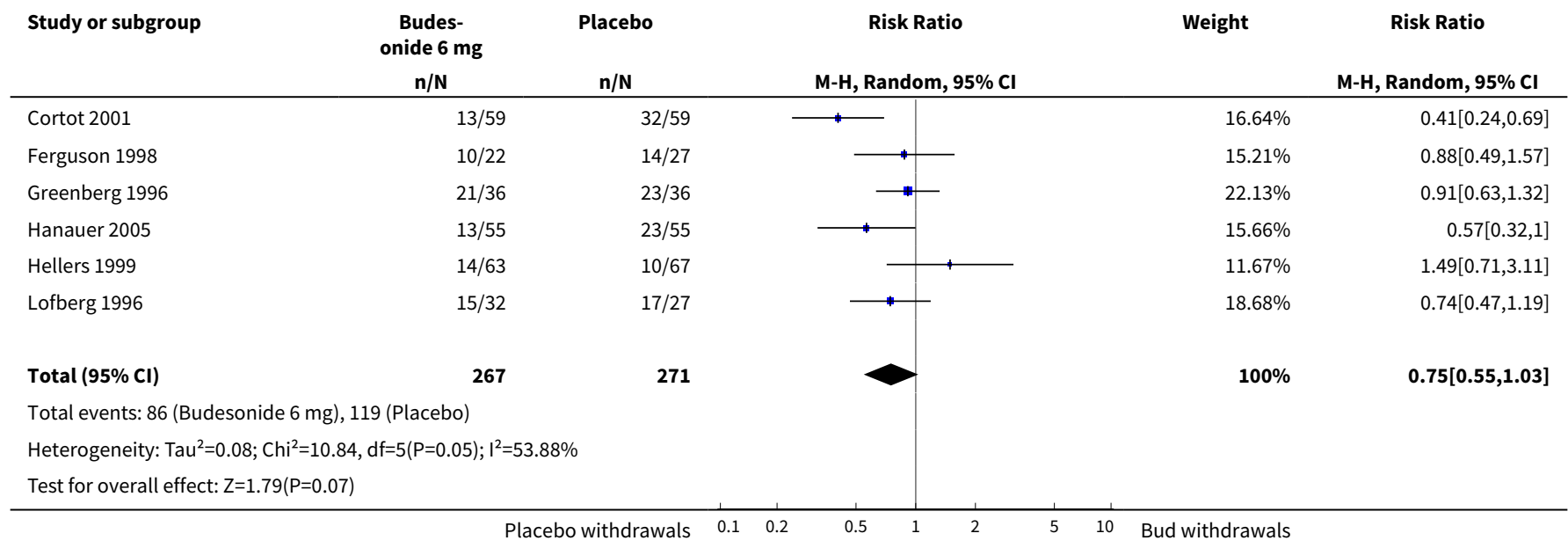

Analysis 1.5. Comparison 1 Budesonide $6 \mathrm{mg}$ vs placebo, Outcome 5 Proportion of Patients with Treatment-Related Adverse Events at 12 Months.

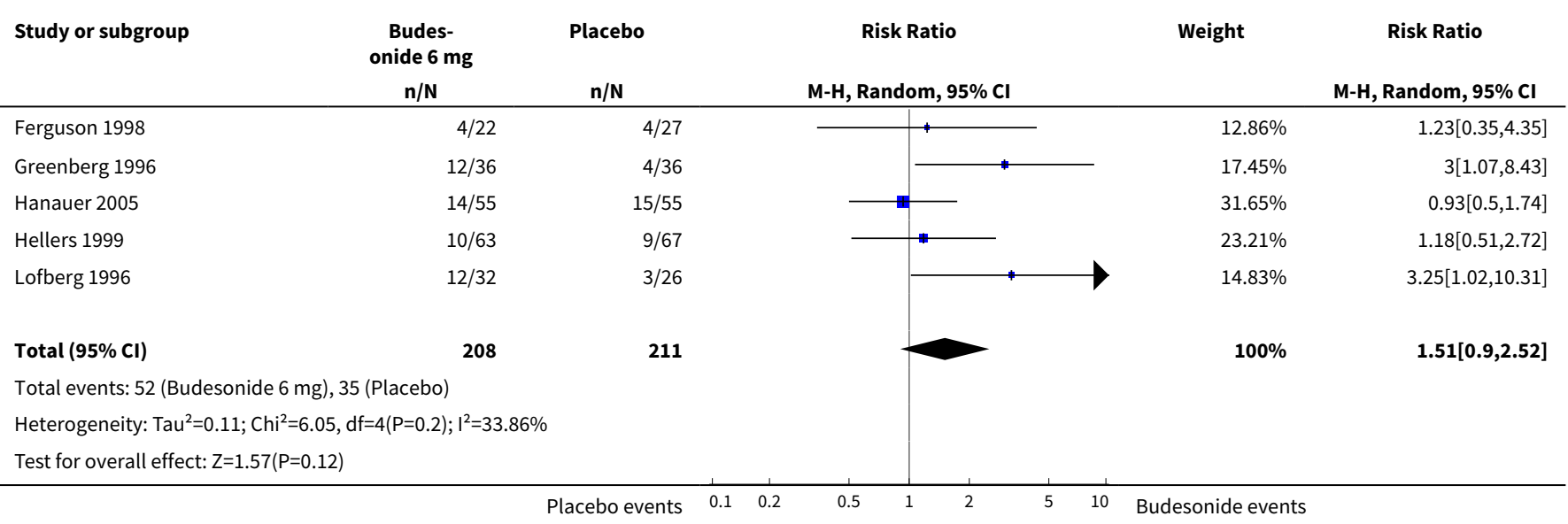

Analysis 1.6. Comparison 1 Budesonide $6 \mathrm{mg}$ vs placebo, Outcome 6 Withdrawals due to Adverse Events.

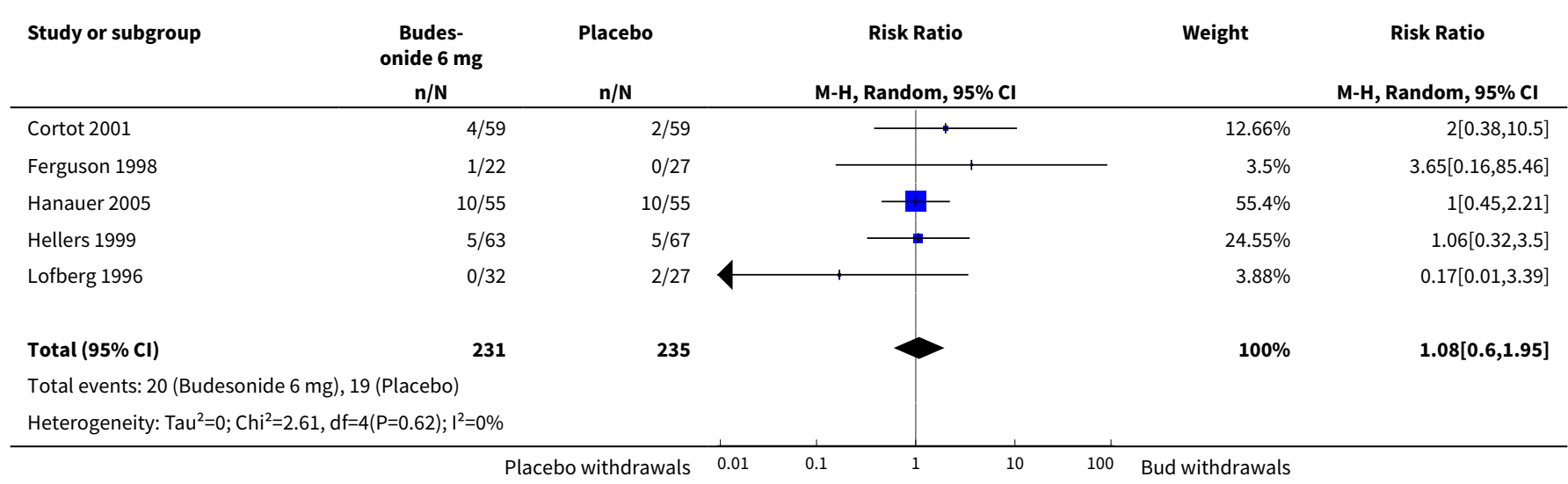




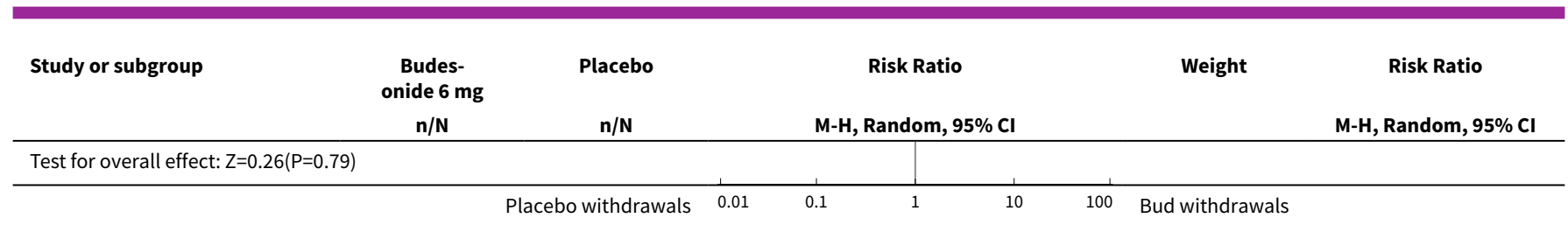

Analysis 1.7. Comparison 1 Budesonide 6 mg vs placebo, Outcome 7 Abnormal ACTH Stimulation Test.

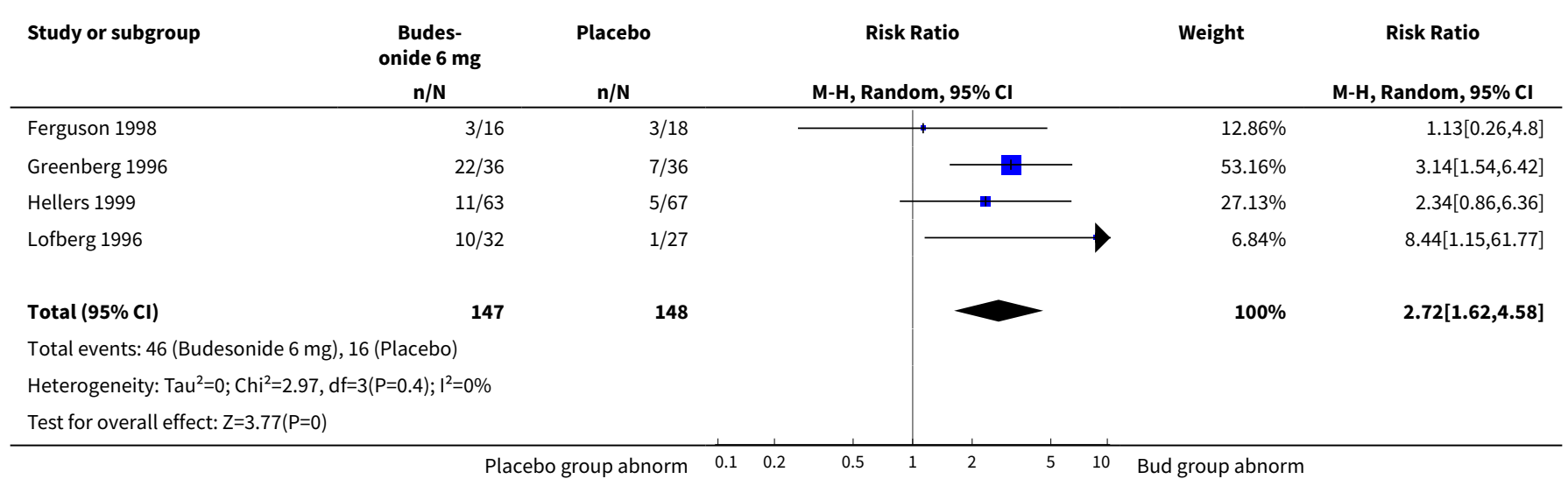

\section{Comparison 2. Budesonide $\mathbf{3} \mathbf{~ m g}$ vs placebo}

\begin{tabular}{|c|c|c|c|c|}
\hline Outcome or subgroup title & No. of studies & $\begin{array}{l}\text { No. of partici- } \\
\text { pants }\end{array}$ & Statistical method & Effect size \\
\hline $\begin{array}{l}1 \text { Maintenance of Clinical Re- } \\
\text { mission }\end{array}$ & 5 & & Risk Ratio (M-H, Random, 95\% Cl) & Subtotals only \\
\hline 1.13 months & 4 & 263 & Risk Ratio (M-H, Random, 95\% Cl) & $1.29[1.01,1.63]$ \\
\hline 1.26 months & 3 & 180 & Risk Ratio (M-H, Random, 95\% Cl) & $1.12[0.83,1.51]$ \\
\hline 1.312 months & 5 & 442 & Risk Ratio (M-H, Random, 95\% CI) & $1.08[0.87,1.34]$ \\
\hline $\begin{array}{l}\text { 1.4 Subgroup ( } \mathrm{pH} \text {-modified } \\
\text { Form) - } 12 \text { months }\end{array}$ & 2 & 262 & Risk Ratio (M-H, Random, 95\% Cl) & $1.13[0.84,1.51]$ \\
\hline $\begin{array}{l}1.5 \text { Subgroup (CIR Form) - } 12 \\
\text { months }\end{array}$ & 3 & 180 & Risk Ratio (M-H, Random, 95\% Cl) & $1.00[0.70,1.42]$ \\
\hline $\begin{array}{l}\text { 1.6 Subgroup (Medical Induc- } \\
\text { tion) - } 3 \text { months }\end{array}$ & 3 & 180 & Risk Ratio (M-H, Random, 95\% Cl) & $1.22[0.93,1.60]$ \\
\hline $\begin{array}{l}1.7 \text { Subgroup (Medical Induc- } \\
\text { tion) - } 12 \text { months }\end{array}$ & 4 & 359 & Risk Ratio (M-H, Random, 95\% Cl) & $0.98[0.75,1.28]$ \\
\hline $\begin{array}{l}2 \text { Change in CDAI from base- } \\
\text { line }\end{array}$ & 4 & & $\begin{array}{l}\text { Mean Difference (IV, Random, 95\% } \\
\mathrm{Cl} \text { ) }\end{array}$ & Subtotals only \\
\hline
\end{tabular}




\begin{tabular}{|c|c|c|c|c|}
\hline Outcome or subgroup title & No. of studies & $\begin{array}{l}\text { No. of partici- } \\
\text { pants }\end{array}$ & Statistical method & Effect size \\
\hline 2.13 months & 4 & 359 & $\begin{array}{l}\text { Mean Difference (IV, Random, 95\% } \\
\mathrm{CI} \text { ) }\end{array}$ & $-0.27[-15.19,14.66]$ \\
\hline 2.26 months & 4 & 359 & $\begin{array}{l}\text { Mean Difference (IV, Random, 95\% } \\
\mathrm{CI} \text { ) }\end{array}$ & $-4.70[-17.99,8.60]$ \\
\hline 2.312 months & 4 & 359 & $\begin{array}{l}\text { Mean Difference (IV, Random, 95\% } \\
\mathrm{CI} \text { ) }\end{array}$ & $17.66[-3.07,38.39]$ \\
\hline 3 Mean Time to Relapse (days) & 5 & 340 & $\begin{array}{l}\text { Mean Difference (IV, Random, 95\% } \\
\mathrm{CI} \text { ) }\end{array}$ & $30.80[8.88,52.71]$ \\
\hline $\begin{array}{l}4 \text { Withdrawals due to Treat- } \\
\text { ment Failure }\end{array}$ & 5 & 442 & Risk Ratio (M-H, Random, 95\% Cl) & $1.02[0.84,1.23]$ \\
\hline $\begin{array}{l}5 \text { Proportion of Patients with } \\
\text { Treatment-Related Adverse } \\
\text { Events at } 12 \text { Months }\end{array}$ & 5 & 440 & Risk Ratio (M-H, Random, 95\% Cl) & $1.19[0.63,2.24]$ \\
\hline $\begin{array}{l}6 \text { Withdrawals due to Adverse } \\
\text { Events }\end{array}$ & 4 & 373 & Risk Ratio (M-H, Random, 95\% Cl) & $0.66[0.20,2.17]$ \\
\hline $\begin{array}{l}7 \text { Abnormal ACTH Stimulation } \\
\text { Test }\end{array}$ & 3 & 164 & Risk Ratio (M-H, Random, 95\% Cl) & $1.89[0.76,4.69]$ \\
\hline
\end{tabular}

Analysis 2.1. Comparison 2 Budesonide $3 \mathrm{mg}$ vs placebo, Outcome 1 Maintenance of Clinical Remission.

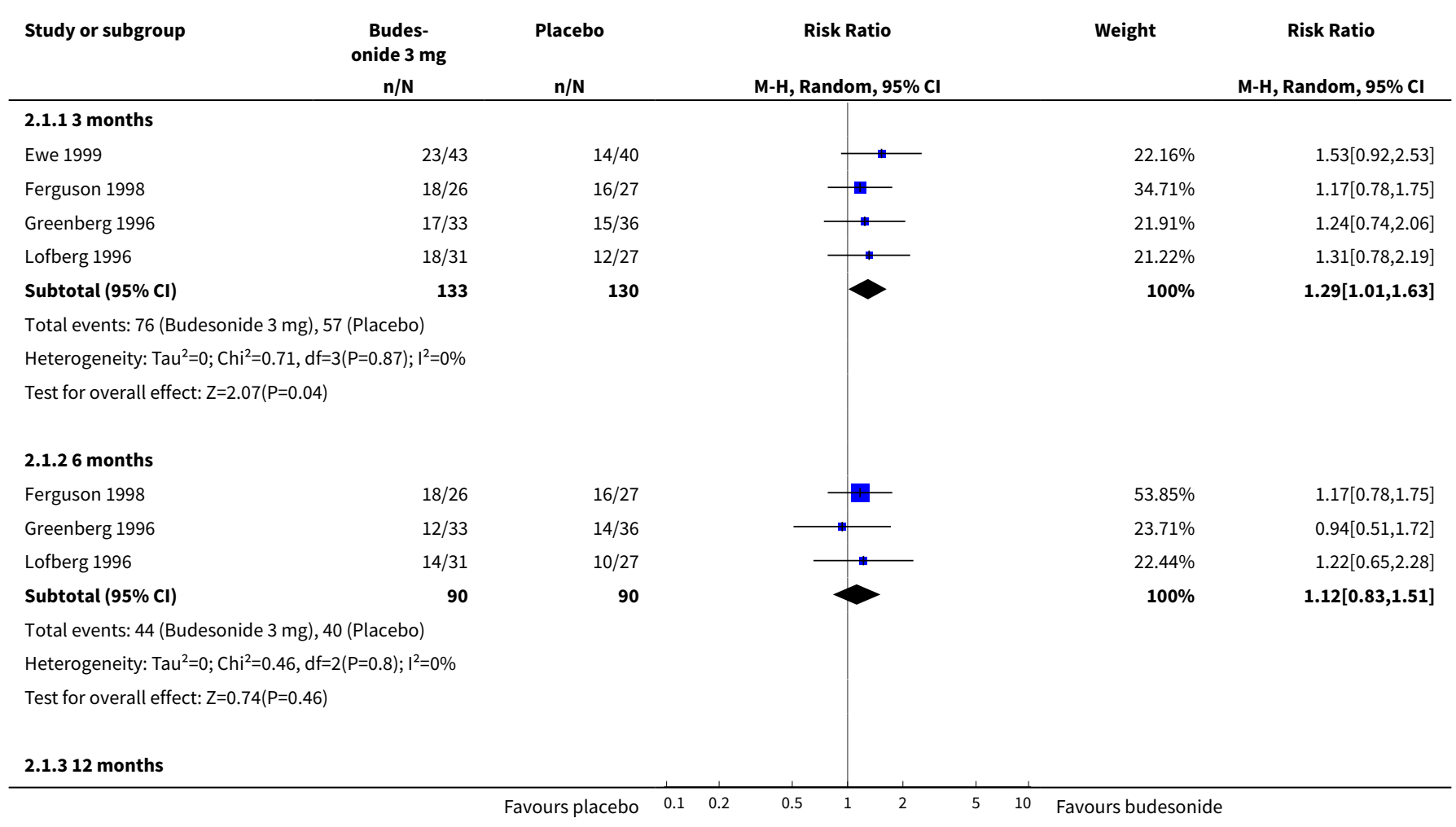




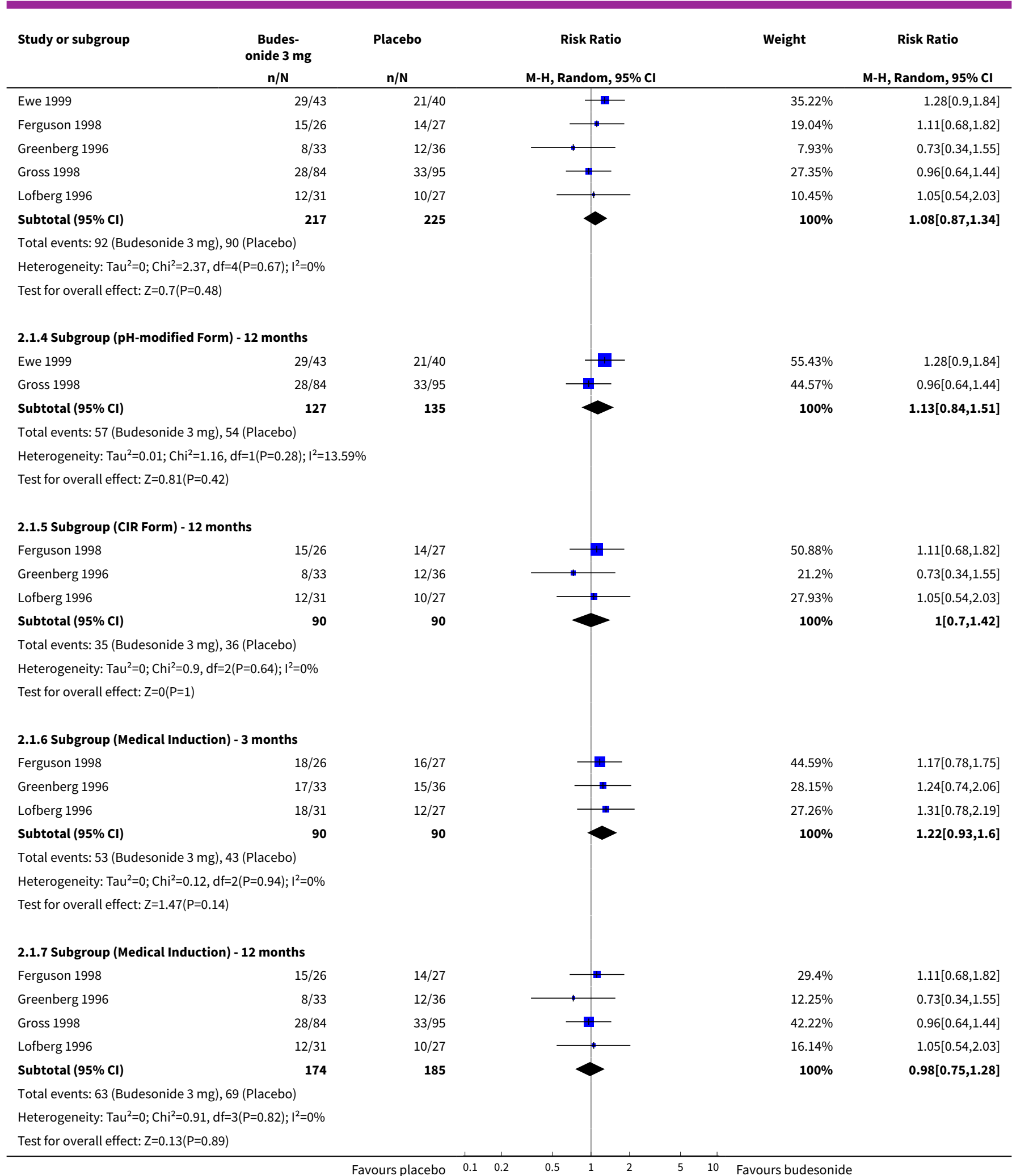


Analysis 2.2. Comparison 2 Budesonide $3 \mathrm{mg}$ vs placebo, Outcome 2 Change in CDAI from baseline.

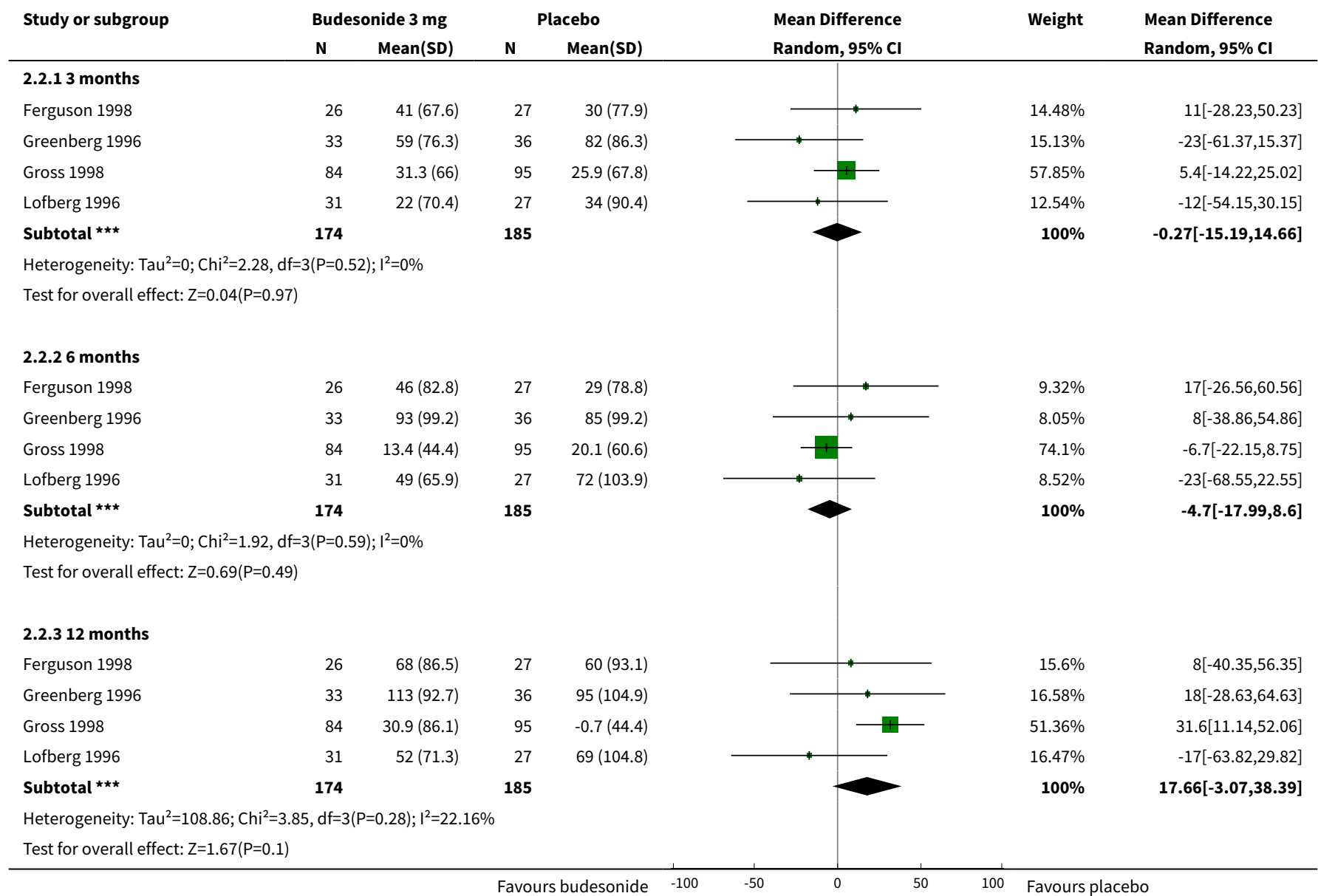

Analysis 2.3. Comparison 2 Budesonide $3 \mathrm{mg}$ vs placebo, Outcome 3 Mean Time to Relapse (days).

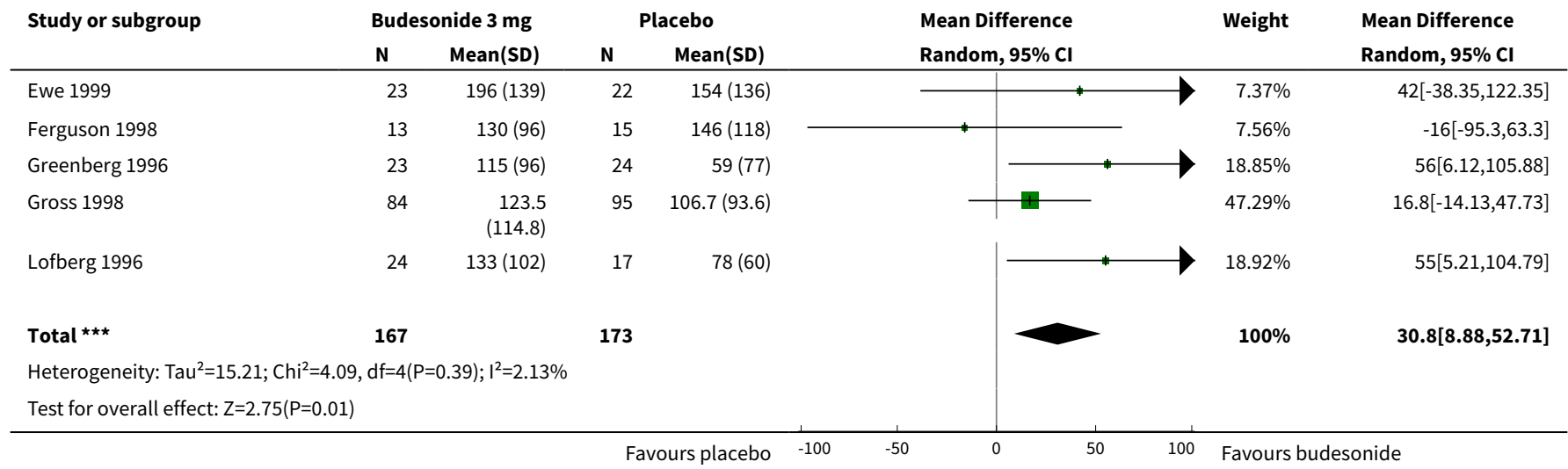


Analysis 2.4. Comparison 2 Budesonide $3 \mathrm{mg}$ vs placebo, Outcome 4 Withdrawals due to Treatment Failure.

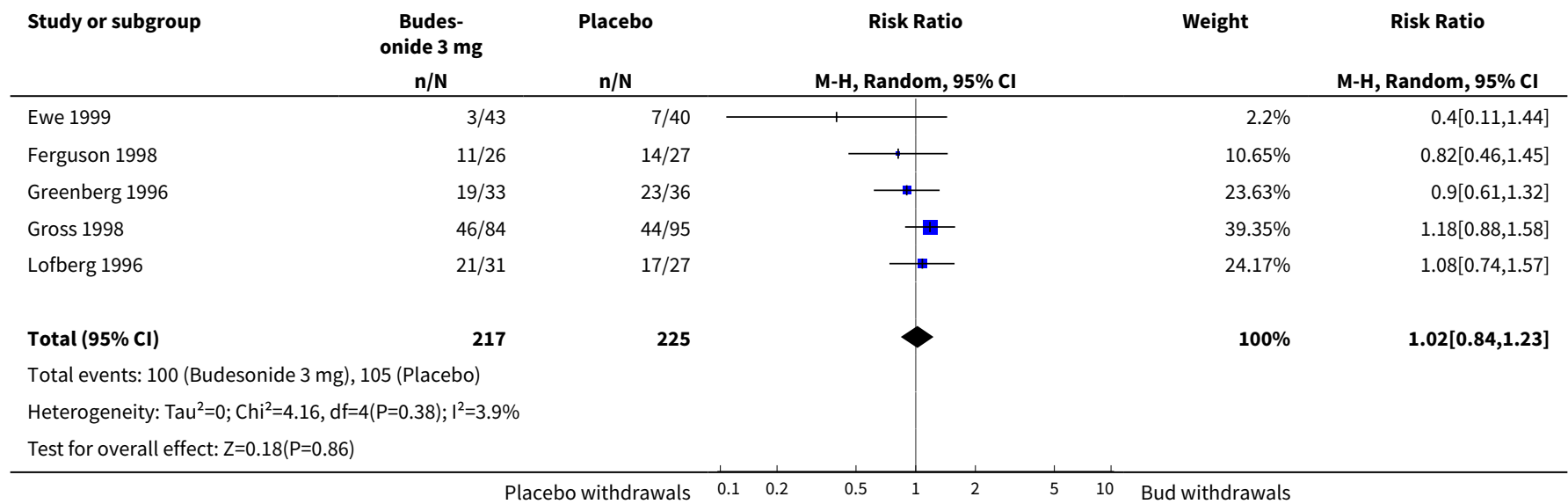

Analysis 2.5. Comparison 2 Budesonide $3 \mathrm{mg}$ vs placebo, Outcome 5 Proportion of Patients with Treatment-Related Adverse Events at 12 Months.

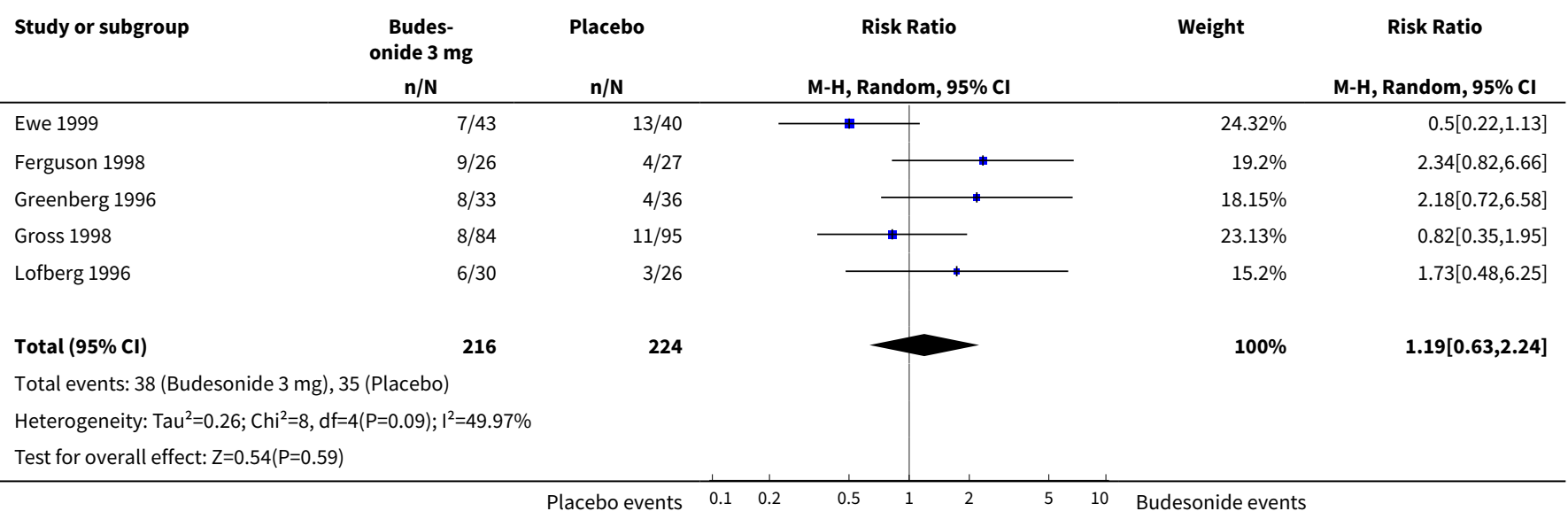

\section{Analysis 2.6. Comparison 2 Budesonide $3 \mathrm{mg}$ vs placebo, Outcome 6 Withdrawals due to Adverse Events.}

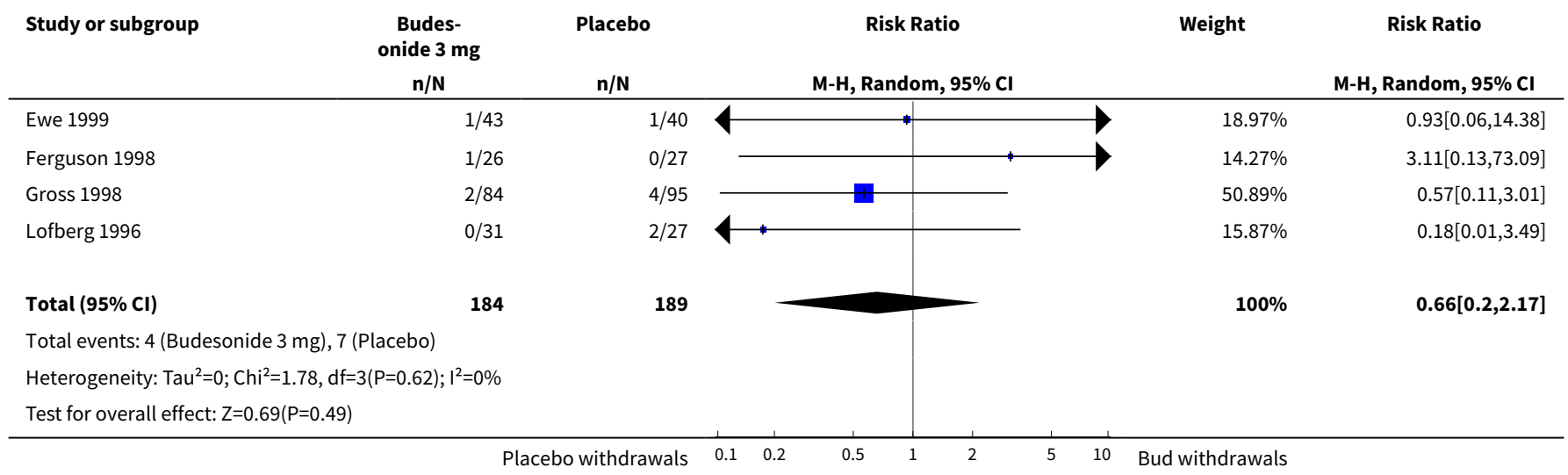


Analysis 2.7. Comparison 2 Budesonide 3 mg vs placebo, Outcome 7 Abnormal ACTH Stimulation Test.

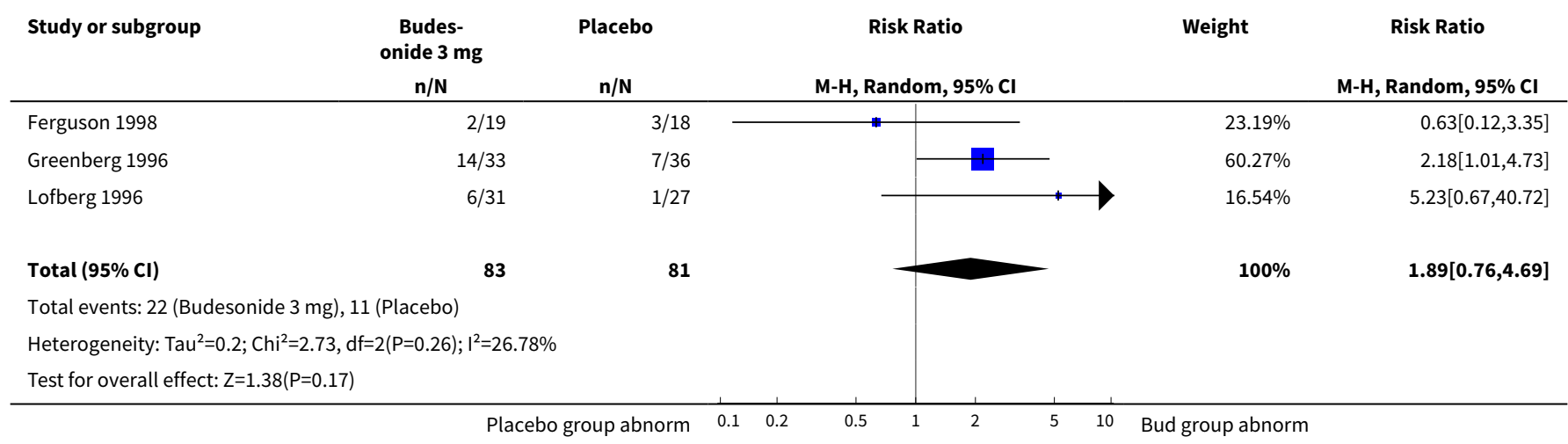

Comparison 3. Withdrawals due to Adverse Events

\begin{tabular}{lllll}
\hline Outcome or subgroup title & No. of studies & $\begin{array}{l}\text { No. of partici- } \\
\text { pants }\end{array}$ & Statistical method & Effect size \\
\hline 1 Budesonide (any dose) vs placebo & 7 & 772 & $\begin{array}{l}\text { Risk Ratio (M-H, Fixed, 95\% } \\
\text { Cl) }\end{array}$ & $0.81[0.48,1.36]$ \\
\hline
\end{tabular}

\section{Analysis 3.1. Comparison 3 Withdrawals due to Adverse Events, Outcome 1 Budesonide (any dose) vs placebo.}

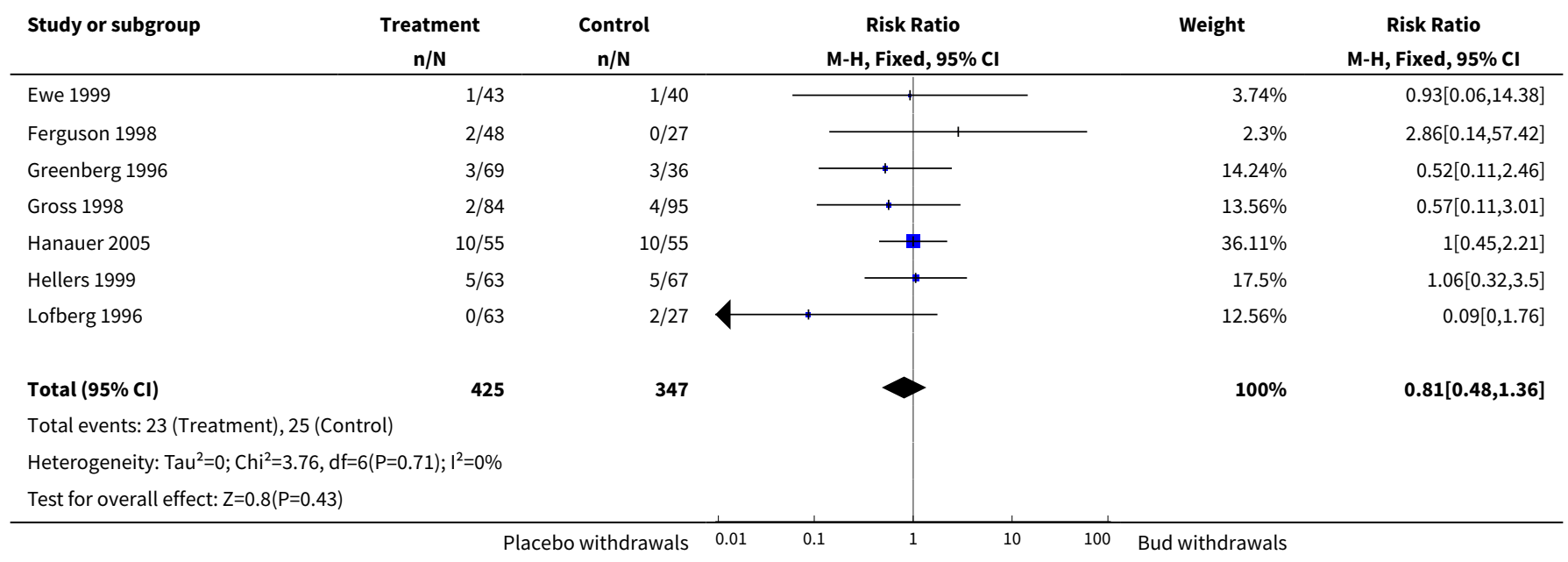


Comparison 4. Budesonide $6 \mathrm{mg}$ vs $3 \mathrm{mg}$

\begin{tabular}{|c|c|c|c|c|}
\hline Outcome or subgroup title & No. of studies & $\begin{array}{l}\text { No. of partici- } \\
\text { pants }\end{array}$ & Statistical method & Effect size \\
\hline $\begin{array}{l}1 \text { Maintenance of Clinical Re- } \\
\text { missions }\end{array}$ & 3 & & Risk Ratio (M-H, Random, 95\% Cl) & Subtotals only \\
\hline 1.13 months & 3 & 180 & Risk Ratio (M-H, Random, 95\% Cl) & $1.07[0.85,1.34]$ \\
\hline 1.26 months & 3 & 180 & Risk Ratio (M-H, Random, 95\% Cl) & $1.12[0.85,1.47]$ \\
\hline 1.312 months & 3 & 180 & Risk Ratio (M-H, Random, 95\% Cl) & $1.18[0.85,1.65]$ \\
\hline $\begin{array}{l}2 \text { Change in CDAI from base- } \\
\text { line }\end{array}$ & 3 & & $\begin{array}{l}\text { Mean Difference (IV, Random, 95\% } \\
\mathrm{CI})\end{array}$ & Subtotals only \\
\hline 2.13 months & 3 & 180 & $\begin{array}{l}\text { Mean Difference (IV, Random, 95\% } \\
\mathrm{CI})\end{array}$ & $-15.11[-41.10,10.88]$ \\
\hline 2.26 months & 3 & 180 & $\begin{array}{l}\text { Mean Difference (IV, Random, 95\% } \\
\mathrm{Cl} \text { ) }\end{array}$ & $-27.44[-52.09,-2.79]$ \\
\hline 2.312 months & 3 & 180 & $\begin{array}{l}\text { Mean Difference (IV, Random, 95\% } \\
\mathrm{Cl} \text { ) }\end{array}$ & $-26.42[-69.55,16.70]$ \\
\hline $\begin{array}{l}3 \text { Mean Time to Relapse } \\
\text { (days) }\end{array}$ & 3 & 117 & $\begin{array}{l}\text { Mean Difference (IV, Random, 95\% } \\
\mathrm{Cl} \text { ) }\end{array}$ & $29.67[-4.83,64.18]$ \\
\hline $\begin{array}{l}4 \text { Withdrawals Due to Treat- } \\
\text { ment Failure }\end{array}$ & 3 & 180 & Risk Ratio (M-H, Random, 95\% Cl) & $0.89[0.68,1.16]$ \\
\hline $\begin{array}{l}5 \text { Proportion of Patients with } \\
\text { Treatment-Related Adverse } \\
\text { Events at } 12 \text { months }\end{array}$ & 3 & 179 & Risk Ratio (M-H, Random, 95\% Cl) & $1.18[0.60,2.32]$ \\
\hline $\begin{array}{l}6 \text { Withdrawals Due to Ad- } \\
\text { verse Events }\end{array}$ & 2 & 111 & Risk Ratio (M-H, Random, 95\% Cl) & $1.18[0.08,17.82]$ \\
\hline $\begin{array}{l}7 \text { Abnormal ACTH Stimula- } \\
\text { tion Test }\end{array}$ & 3 & 167 & Risk Ratio (M-H, Random, 95\% Cl) & $1.49[1.00,2.24]$ \\
\hline
\end{tabular}

Analysis 4.1. Comparison 4 Budesonide $6 \mathrm{mg}$ vs $3 \mathrm{mg}$, Outcome 1 Maintenance of Clinical Remissions.

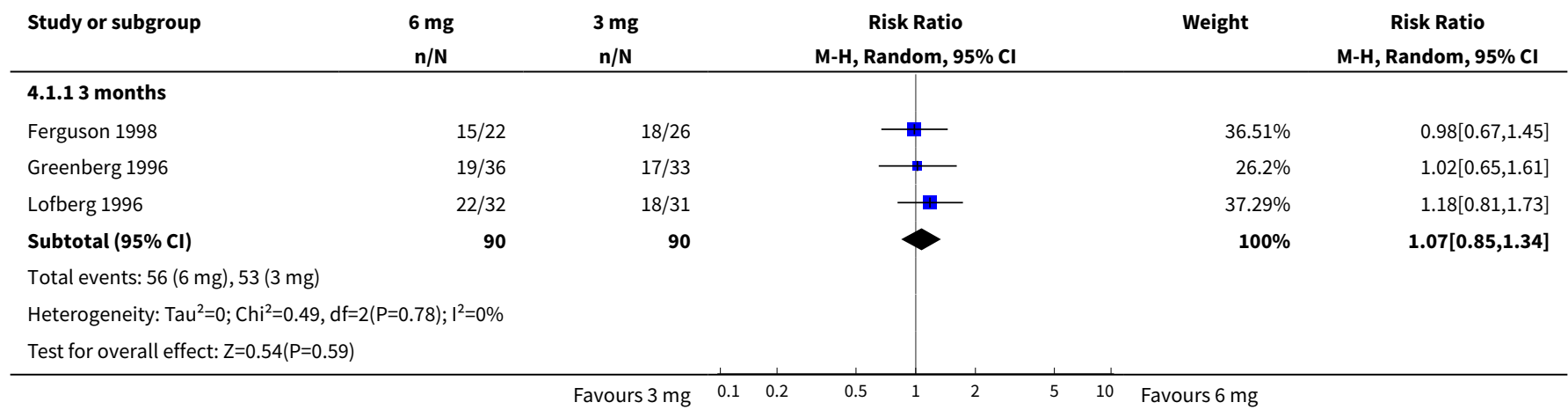




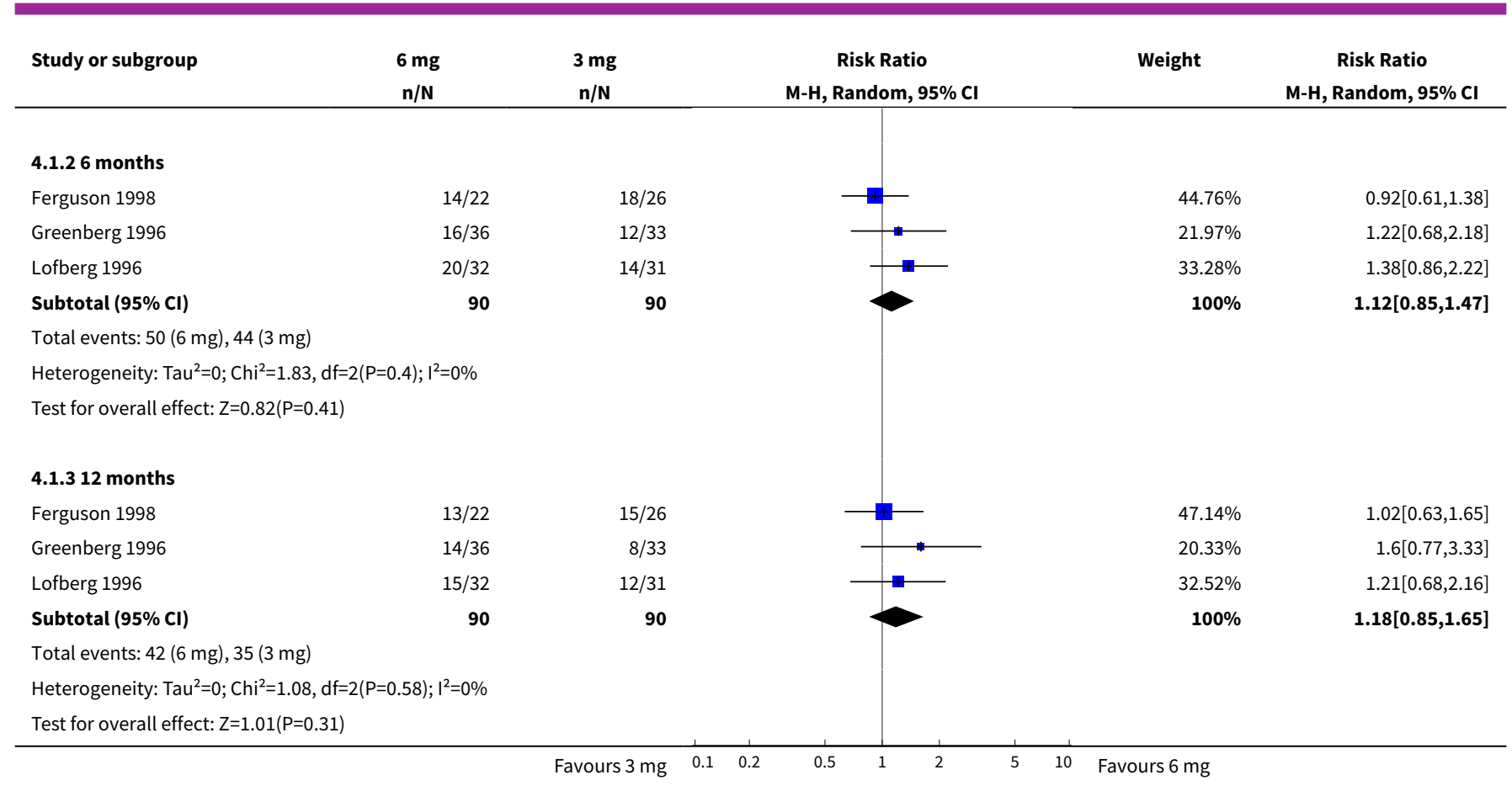

Analysis 4.2. Comparison 4 Budesonide $6 \mathrm{mg}$ vs $3 \mathrm{mg}$, Outcome 2 Change in CDAl from baseline.

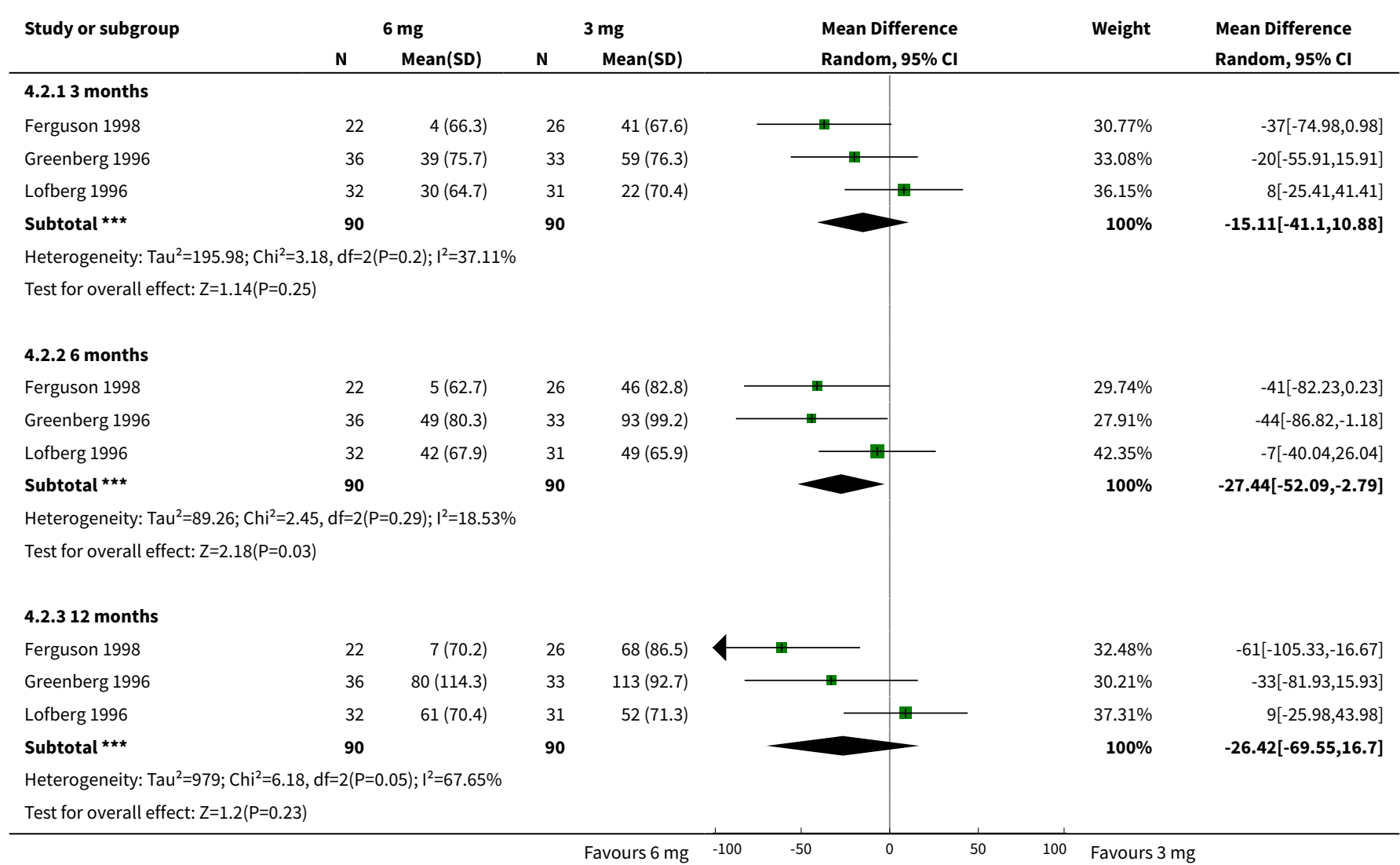


Analysis 4.3. Comparison 4 Budesonide $6 \mathrm{mg}$ vs $3 \mathrm{mg}$, Outcome 3 Mean Time to Relapse (days).

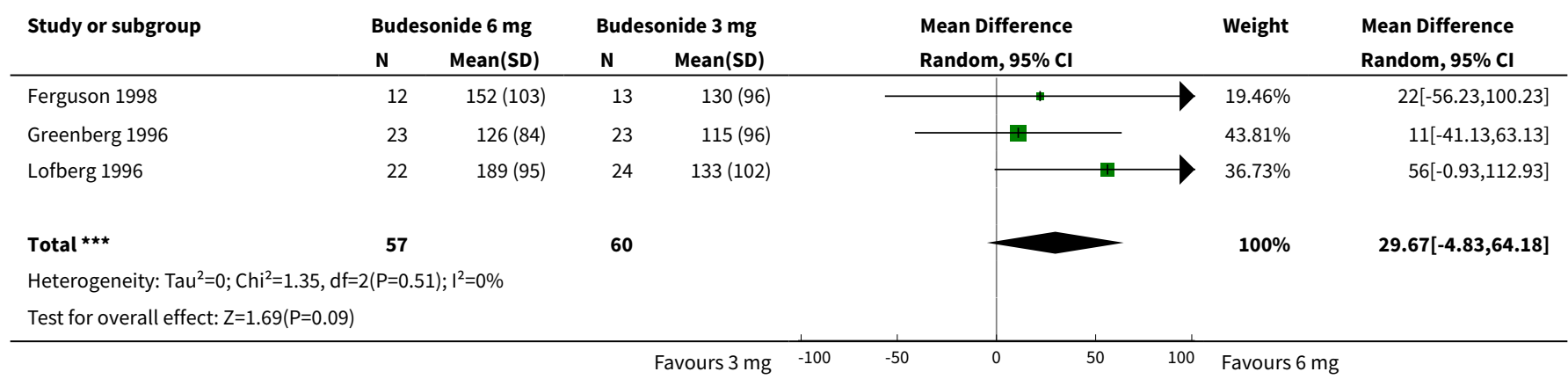

Analysis 4.4. Comparison 4 Budesonide $6 \mathrm{mg}$ vs $3 \mathrm{mg}$, Outcome 4 Withdrawals Due to Treatment Failure.

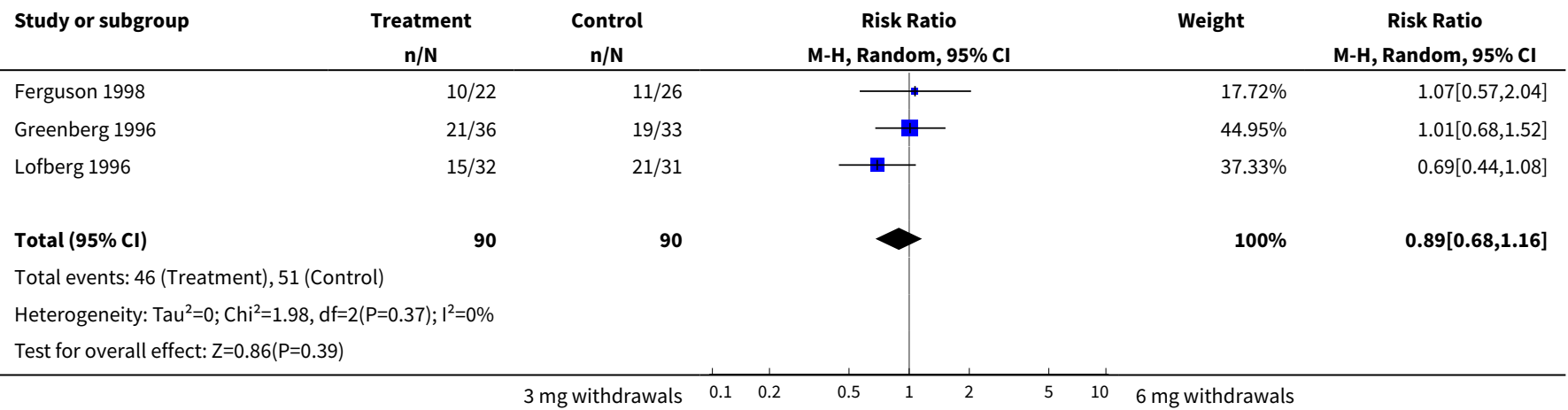

Analysis 4.5. Comparison 4 Budesonide $6 \mathrm{mg} v s 3 \mathrm{mg}$, Outcome 5 Proportion of Patients with Treatment-Related Adverse Events at 12 months.

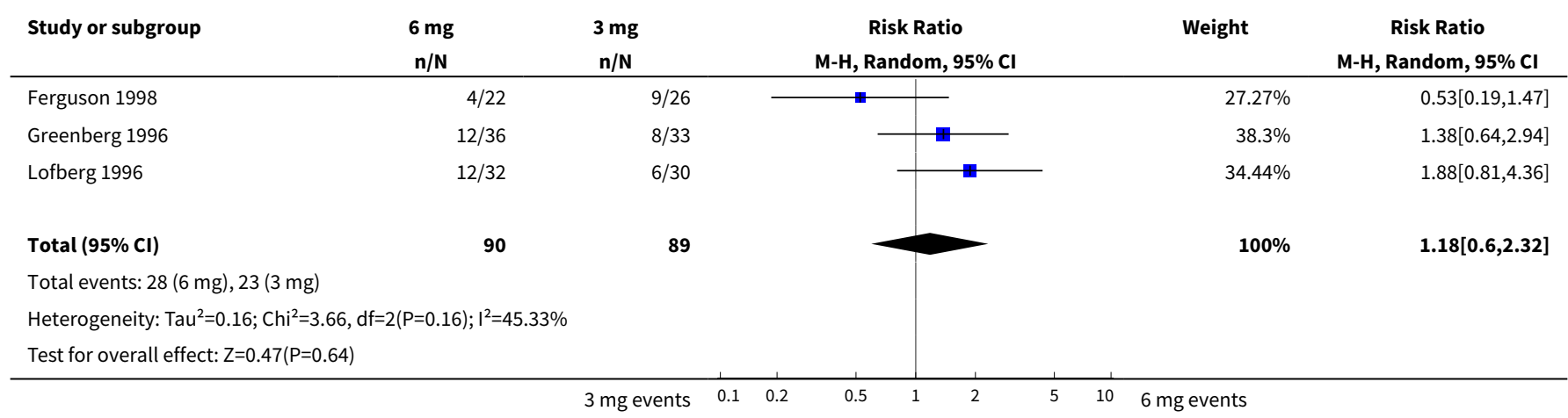


Analysis 4.6. Comparison 4 Budesonide $6 \mathrm{mg}$ vs $3 \mathrm{mg}$, Outcome 6 Withdrawals Due to Adverse Events.

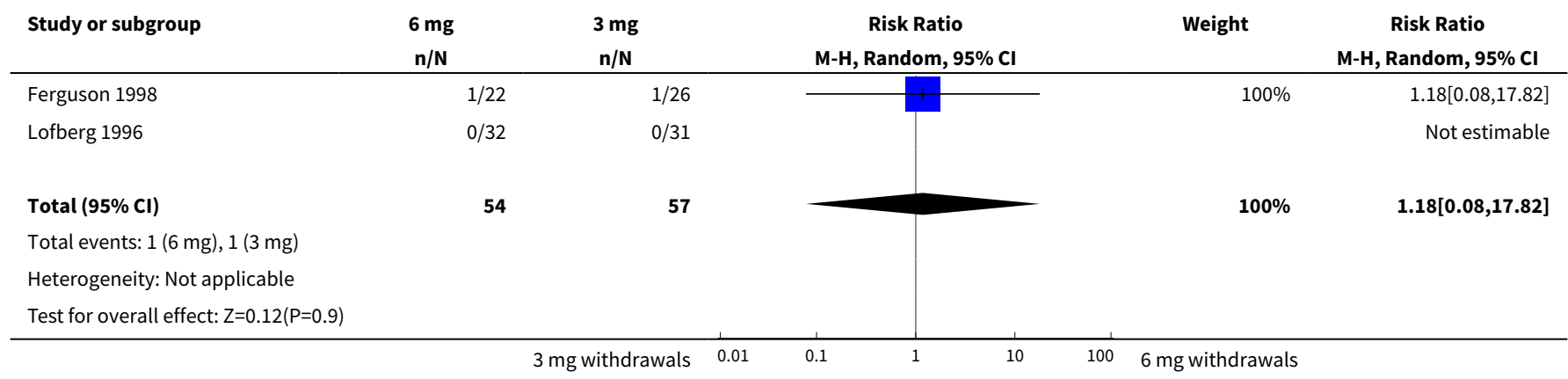

Analysis 4.7. Comparison 4 Budesonide $6 \mathrm{mg}$ vs $3 \mathrm{mg}$, Outcome 7 Abnormal ACTH Stimulation Test.

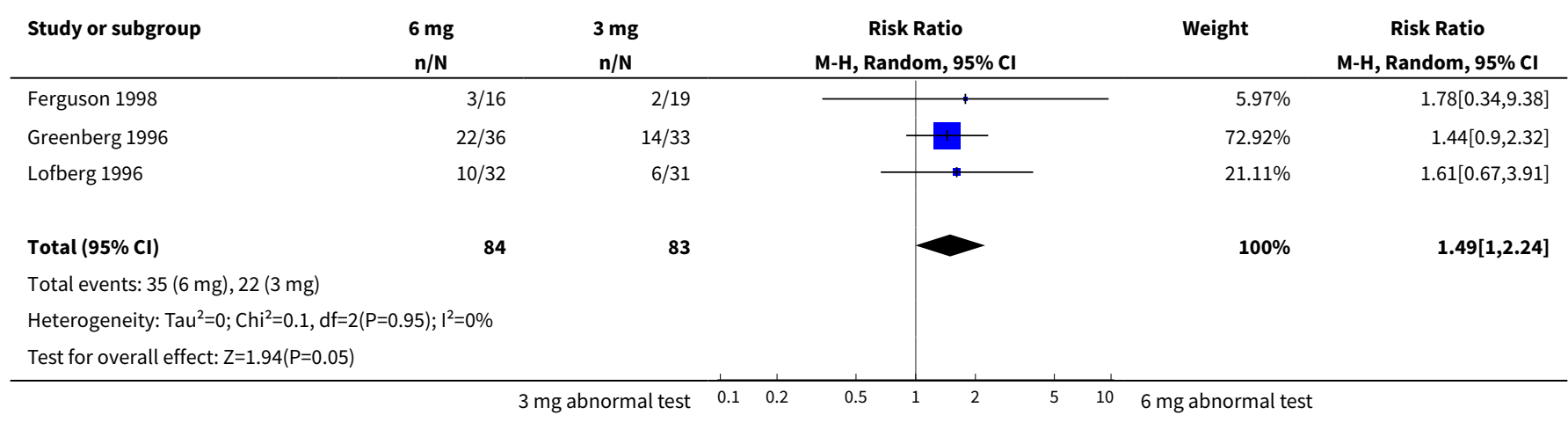

\section{Comparison 5. Budesonide $9 \mathrm{mg}$ vs $6 \mathrm{mg}$}

\begin{tabular}{|c|c|c|c|c|}
\hline Outcome or subgroup title & No. of studies & $\begin{array}{l}\text { No. of partici- } \\
\text { pants }\end{array}$ & Statistical method & Effect size \\
\hline 1 Maintenance of Clinical Remission & 1 & 157 & $\begin{array}{l}\text { Risk Ratio (M-H, Random, 95\% } \\
\mathrm{Cl})\end{array}$ & $1.07[0.91,1.26]$ \\
\hline 2 Change in CDAI from baseline & 1 & & $\begin{array}{l}\text { Mean Difference (IV, Random, } \\
95 \% \mathrm{CI})\end{array}$ & Subtotals only \\
\hline 2.112 months & 1 & 157 & $\begin{array}{l}\text { Mean Difference (IV, Random, } \\
95 \% \mathrm{CI})\end{array}$ & $-18.0[-41.06,5.06]$ \\
\hline $\begin{array}{l}3 \text { Withdrawals Due to Treatment } \\
\text { Failure }\end{array}$ & 1 & 157 & $\begin{array}{l}\text { Risk Ratio (M-H, Random, 95\% } \\
\mathrm{Cl})\end{array}$ & $0.99[0.55,1.78]$ \\
\hline $\begin{array}{l}4 \text { Proportion of Patients with Treat- } \\
\text { ment-Related Adverse Events at } 12 \\
\text { Months }\end{array}$ & 1 & 157 & $\begin{array}{l}\text { Risk Ratio (M-H, Random, 95\% } \\
\mathrm{Cl})\end{array}$ & $1.12[0.89,1.42]$ \\
\hline $\begin{array}{l}5 \text { Withdrawals Due to Adverse } \\
\text { Events }\end{array}$ & 1 & 157 & $\begin{array}{l}\text { Risk Ratio (M-H, Random, 95\% } \\
\text { Cl) }\end{array}$ & $0.31[0.03,2.94]$ \\
\hline
\end{tabular}


Analysis 5.1. Comparison 5 Budesonide $9 \mathrm{mg}$ vs $6 \mathrm{mg}$, Outcome 1 Maintenance of Clinical Remission.

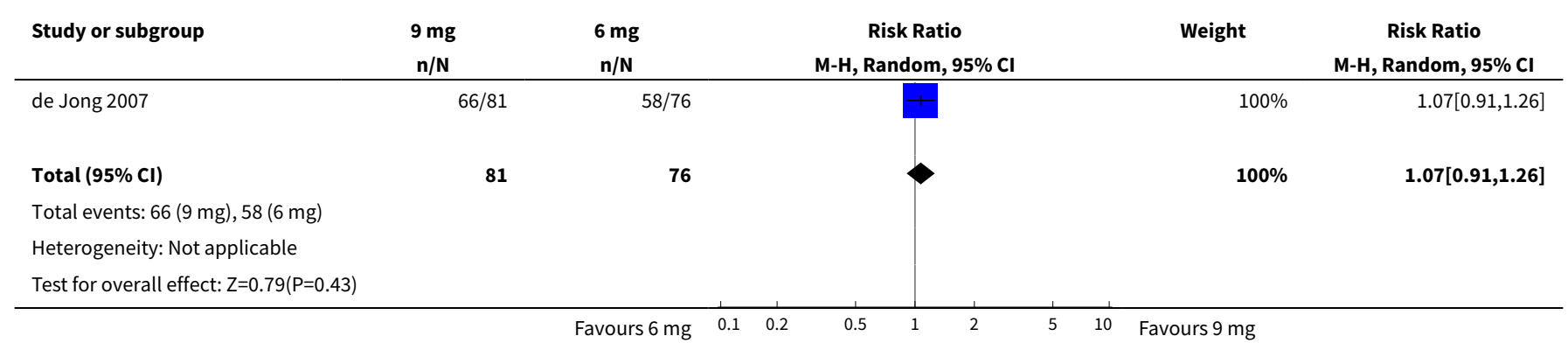

Analysis 5.2. Comparison 5 Budesonide $9 \mathrm{mg}$ vs $6 \mathrm{mg}$, Outcome 2 Change in CDAl from baseline.

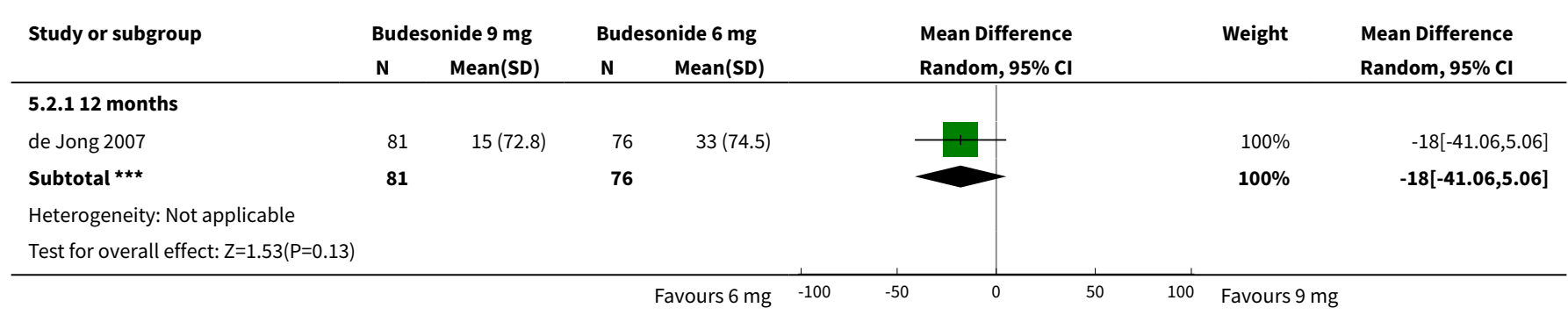

Analysis 5.3. Comparison 5 Budesonide $9 \mathrm{mg}$ vs $6 \mathrm{mg}$, Outcome 3 Withdrawals Due to Treatment Failure.

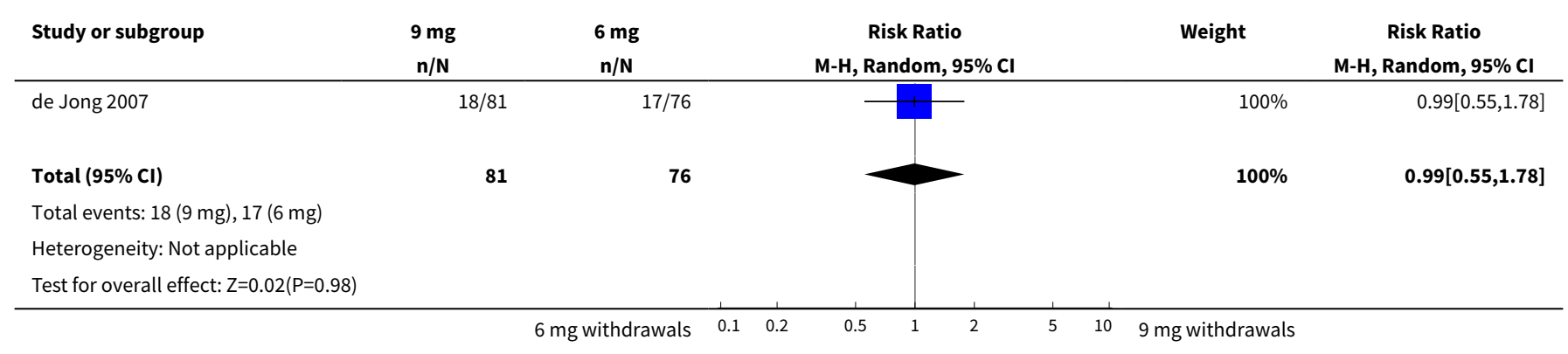

Analysis 5.4. Comparison 5 Budesonide $9 \mathrm{mg}$ vs $6 \mathrm{mg}$, Outcome 4 Proportion of Patients with Treatment-Related Adverse Events at 12 Months.

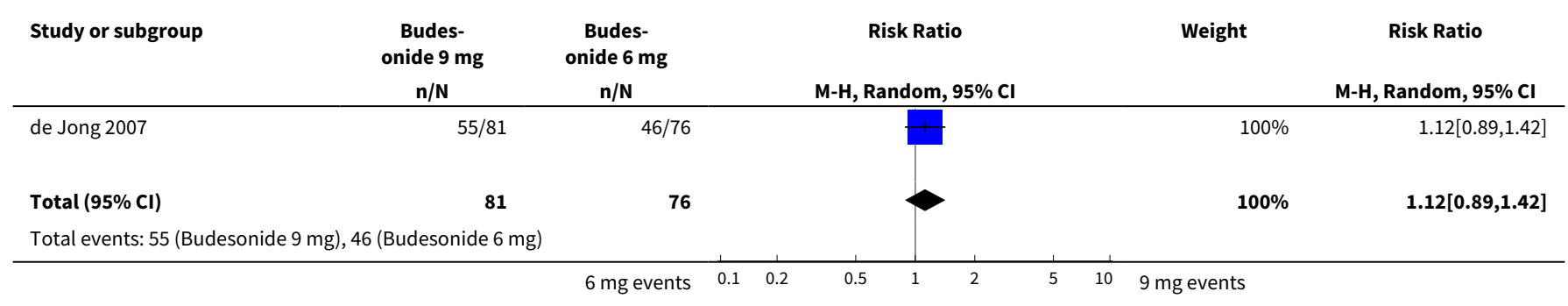




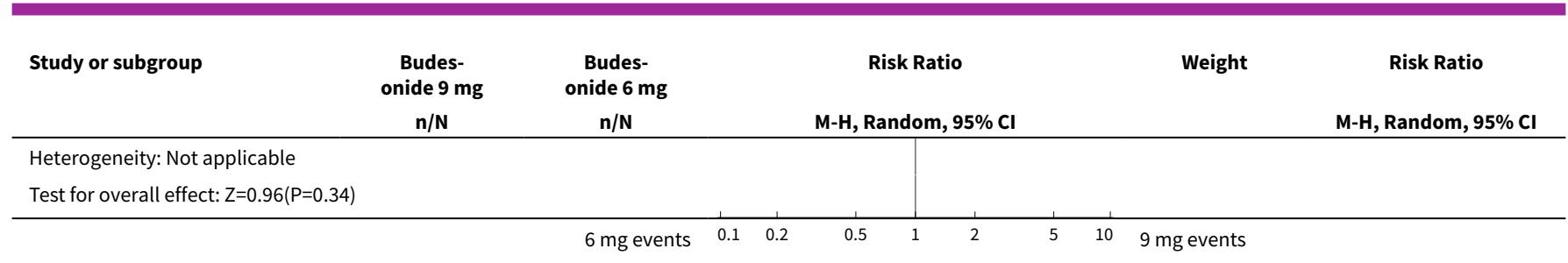

Analysis 5.5. Comparison 5 Budesonide $9 \mathrm{mg}$ vs $6 \mathrm{mg}$, Outcome 5 Withdrawals Due to Adverse Events.

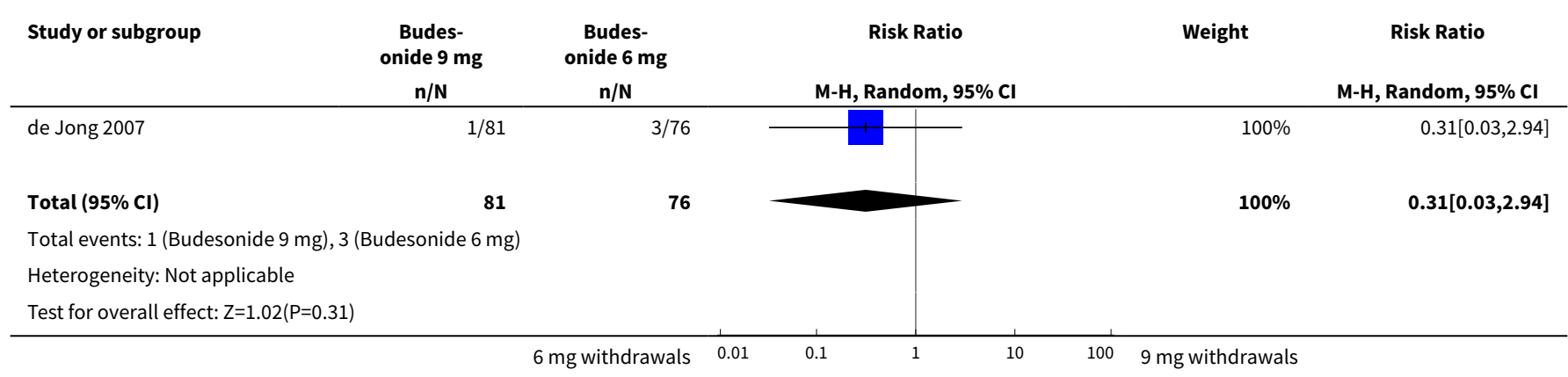

\section{Comparison 6. Budesonide $9 \mathrm{mg} /$ day vs prednisolone $40 \mathrm{mg} /$ day (weaning)}

\begin{tabular}{lllll}
\hline Outcome or subgroup title & No. of studies & $\begin{array}{l}\text { No. of partici- } \\
\text { pants }\end{array}$ & Statistical method & Effect size \\
\hline $\begin{array}{l}1 \text { Maintenance of Clinical Re- } \\
\text { mission }\end{array}$ & 1 & & Risk Ratio (M-H, Random, 95\% Cl) & Subtotals only \\
\hline $\begin{array}{l}1.13 \text { months } \\
1.26 \text { months }\end{array}$ & 1 & 90 & Risk Ratio (M-H, Random, 95\% Cl) & $0.81[0.60,1.09]$ \\
\hline $\begin{array}{l}1.312 \text { months } \\
2 \text { Withdrawals Due to Treat- } \\
\text { ment Failure }\end{array}$ & 1 & 90 & Risk Ratio (M-H, Random, 95\% Cl) & $0.79[0.56,1.12]$ \\
\hline $\begin{array}{l}3 \text { Withdrawals Due to Ad- } \\
\text { verse Events }\end{array}$ & 1 & 90 & Risk Ratio (M-H, Random, 95\% Cl) & $0.79[0.55,1.13]$ \\
\hline $\begin{array}{l}4 \text { Abnormal ACTH Stimula- } \\
\text { tion Test }\end{array}$ & 1 & 90 & Risk Ratio (M-H, Fixed, 95\% Cl) & $1.65[0.89,3.06]$ \\
\hline
\end{tabular}


Analysis 6.1. Comparison 6 Budesonide $9 \mathrm{mg} /$ day vs prednisolone $40 \mathrm{mg} /$ day (weaning), Outcome 1 Maintenance of Clinical Remission.

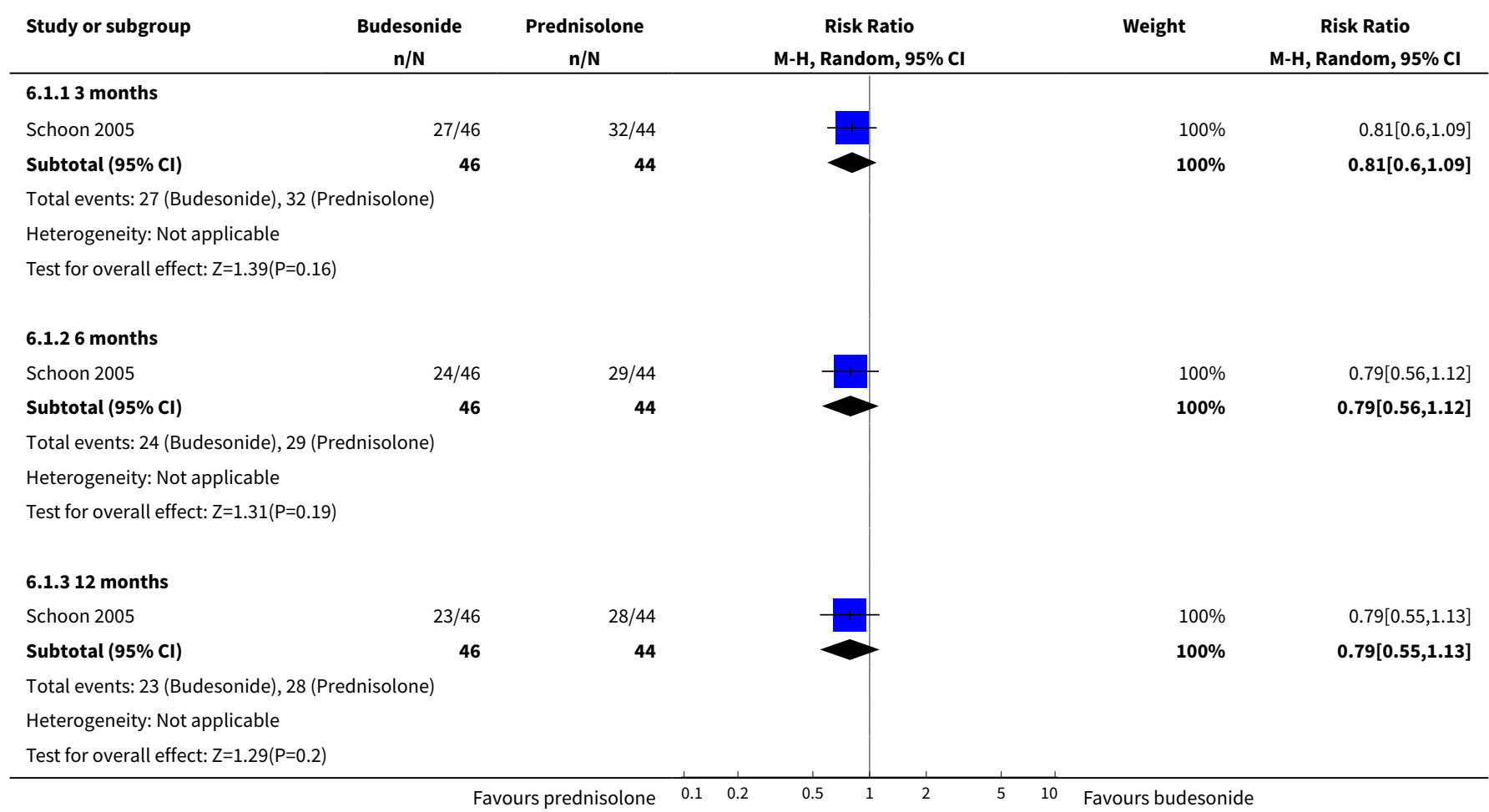

Analysis 6.2. Comparison 6 Budesonide $9 \mathrm{mg} /$ day vs prednisolone 40 $\mathrm{mg} /$ day (weaning), Outcome 2 Withdrawals Due to Treatment Failure.

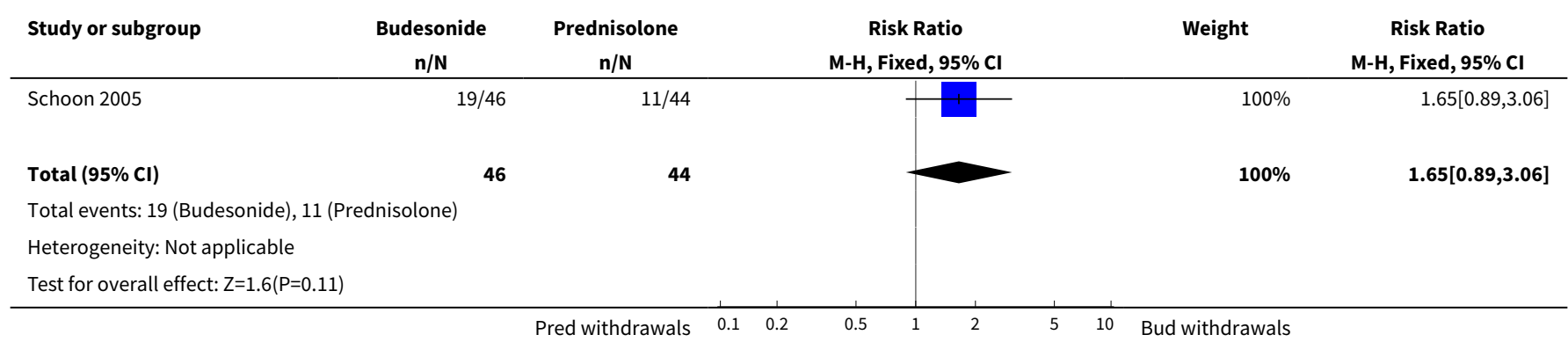

Analysis 6.3. Comparison 6 Budesonide $9 \mathrm{mg}$ /day vs prednisolone 40 $\mathrm{mg} /$ day (weaning), Outcome 3 Withdrawals Due to Adverse Events.

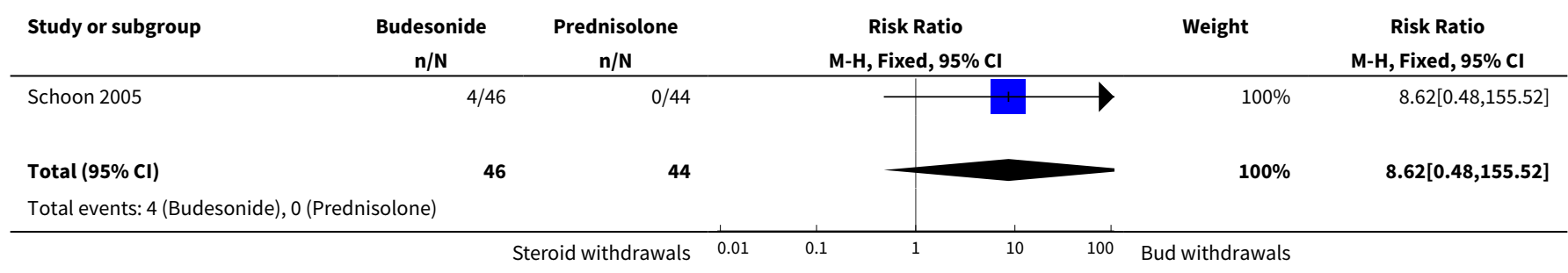




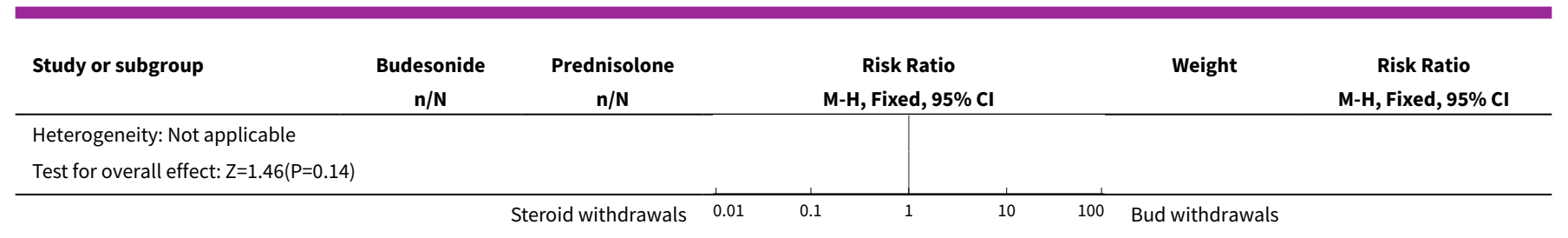

Analysis 6.4. Comparison 6 Budesonide $9 \mathrm{mg} / \mathrm{day}$ vs prednisolone $40 \mathrm{mg} /$ day (weaning), Outcome 4 Abnormal ACTH Stimulation Test.

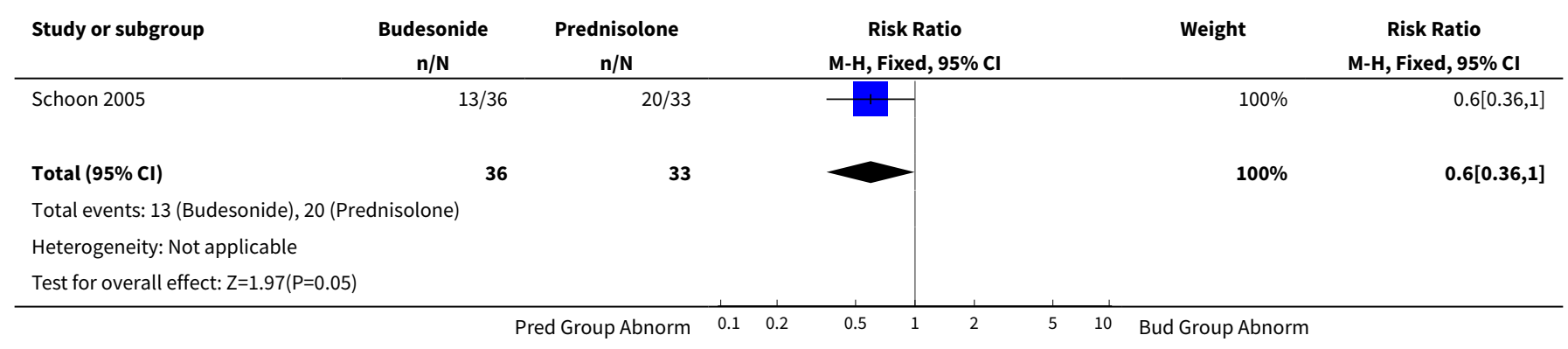

\section{Comparison 7. Budesonide $6 \mathrm{mg}$ vs mesalamine $3 \mathrm{~g} / \mathrm{day}$}

\begin{tabular}{lllll}
\hline Outcome or subgroup title & No. of studies & $\begin{array}{l}\text { No. of partici- } \\
\text { pants }\end{array}$ & Statistical method & Effect size \\
\hline $\begin{array}{lllll}1 \text { Maintenance of clinical remission } \\
\text { Paithdrawals Due to Treatment }\end{array}$ & 1 & 57 & $\begin{array}{l}\text { Risk Ratio (M-H, Random, 95\% } \\
\mathrm{Cl})\end{array}$ & $2.51[1.03,6.12]$ \\
\hline \begin{tabular}{l} 
Failure \\
\hline
\end{tabular} & 57 & $\begin{array}{l}\text { Risk Ratio (M-H, Random, 95\% } \\
\mathrm{Cl})\end{array}$ & $0.67[0.46,0.97]$ \\
\hline
\end{tabular}

Analysis 7.1. Comparison 7 Budesonide $6 \mathrm{mg}$ vs mesalamine $3 \mathrm{~g} / \mathrm{day}$, Outcome 1 Maintenance of clinical remission.

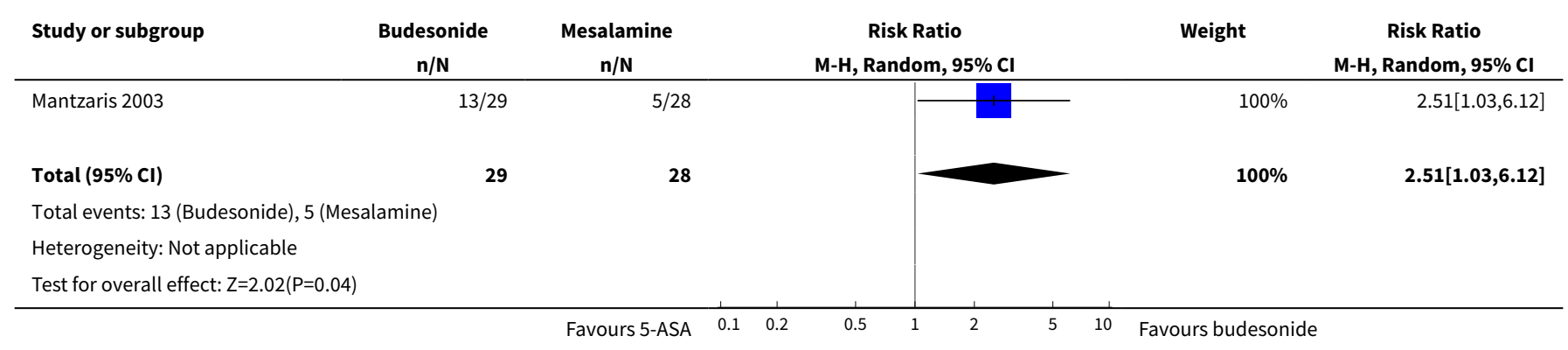


Analysis 7.2. Comparison 7 Budesonide $6 \mathrm{mg}$ vs mesalamine $3 \mathrm{~g} /$ day, Outcome 2 Withdrawals Due to Treatment Failure.

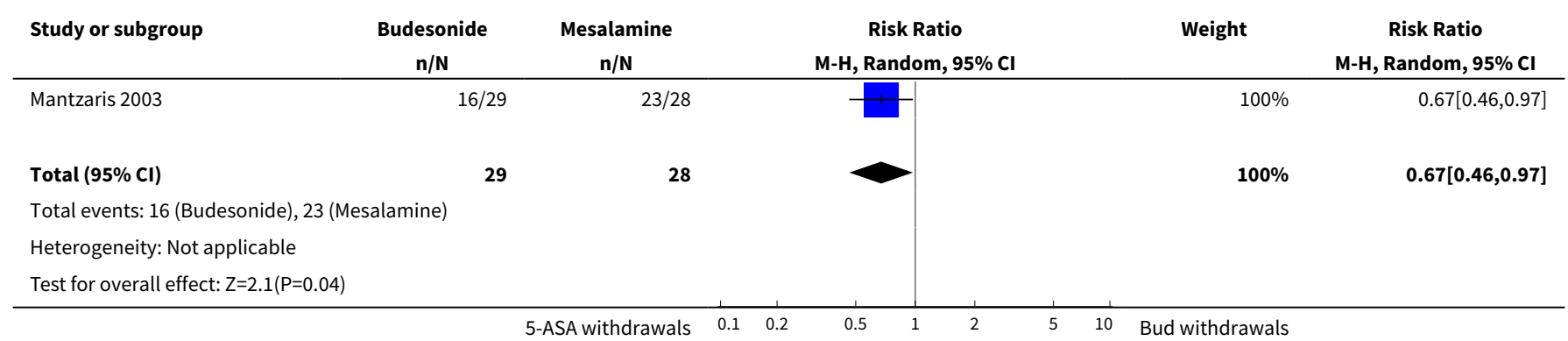

Comparison 8. Budesonide 6-9 mg vs azathioprine $2.0-2.5 \mathrm{mg} / \mathrm{kg} / \mathrm{day}$

\begin{tabular}{lllll}
\hline Outcome or subgroup title & No. of studies & $\begin{array}{l}\text { No. of partici- } \\
\text { pants }\end{array}$ & Statistical method & Effect size \\
\hline $\begin{array}{l}1 \text { Maintenance of clinical remis- } \\
\text { sion }\end{array}$ & 1 & 77 & $\begin{array}{l}\text { Risk Ratio (M-H, Random, 95\% } \\
\text { Cl) }\end{array}$ & $0.81[0.61,1.08]$ \\
\hline 2 Mean time to relapse & 1 & 77 & $\begin{array}{l}\text { Mean Difference (IV, Random, } \\
95 \% \text { Cl) }\end{array}$ & $-58.0[-96.68$, \\
\hline $\begin{array}{l}3 \text { Withdrawals due to treatment } \\
\text { failure }\end{array}$ & 1 & & $\begin{array}{l}\text { Risk Ratio (M-H, Random, 95\% } \\
\text { Cl) }\end{array}$ & $2.27[0.98,5.30]$ \\
\hline $\begin{array}{l}4 \text { Withdrawls due to adverse } \\
\text { events }\end{array}$ & 1 & 77 & $\begin{array}{l}\text { Risk Ratio (M-H, Random, 95\% } \\
\text { Cl) }\end{array}$ & 0.19 [0.01, 3.93] \\
\hline
\end{tabular}

Analysis 8.1. Comparison 8 Budesonide 6-9 mg vs azathioprine 2.0-2.5 $\mathrm{mg} / \mathrm{kg} / \mathrm{day}$, Outcome 1 Maintenance of clinical remission.

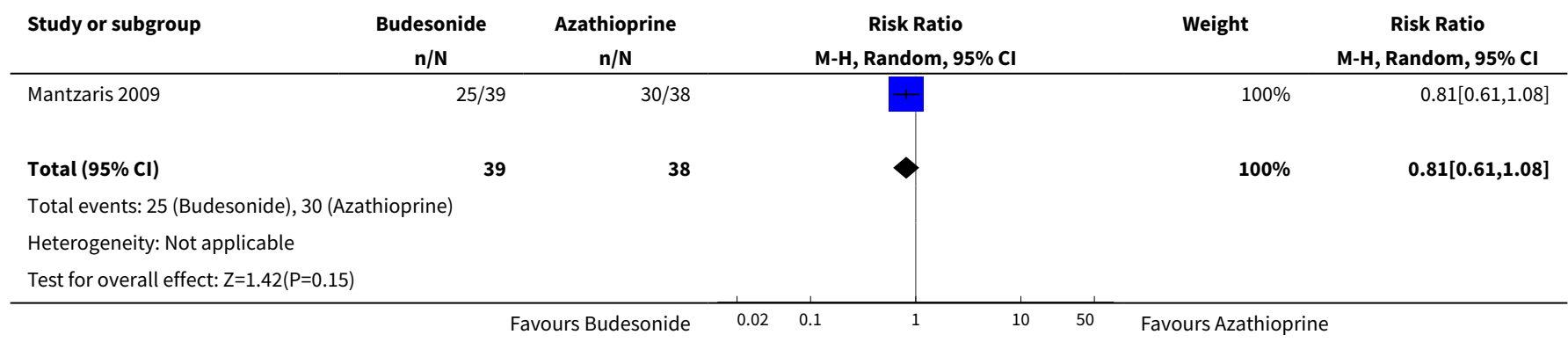


Analysis 8.2. Comparison 8 Budesonide 6-9 mg vs azathioprine 2.0-2.5 mg/kg/day, Outcome 2 Mean time to relapse.

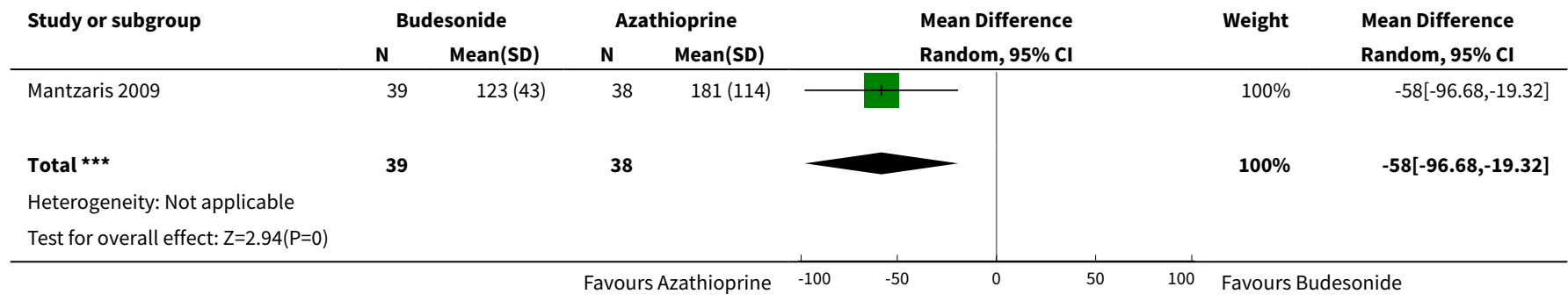

Analysis 8.3. Comparison 8 Budesonide 6-9 mg vs azathioprine 2.0-2.5 $\mathrm{mg} / \mathrm{kg} / \mathrm{day}$, Outcome 3 Withdrawals due to treatment failure.

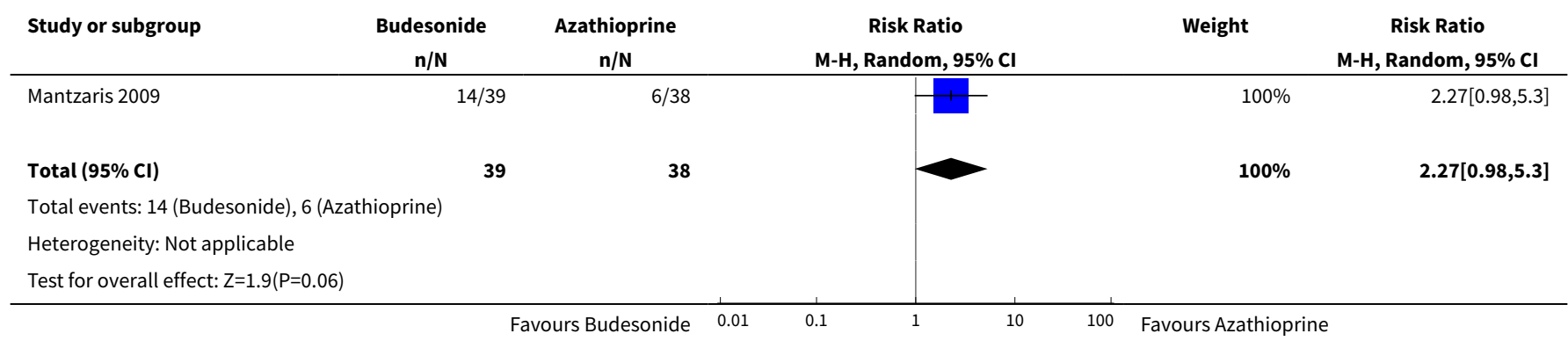

Analysis 8.4. Comparison 8 Budesonide 6-9 mg vs azathioprine 2.0-2.5 $\mathrm{mg} / \mathrm{kg} / \mathrm{day}$, Outcome 4 Withdrawls due to adverse events.

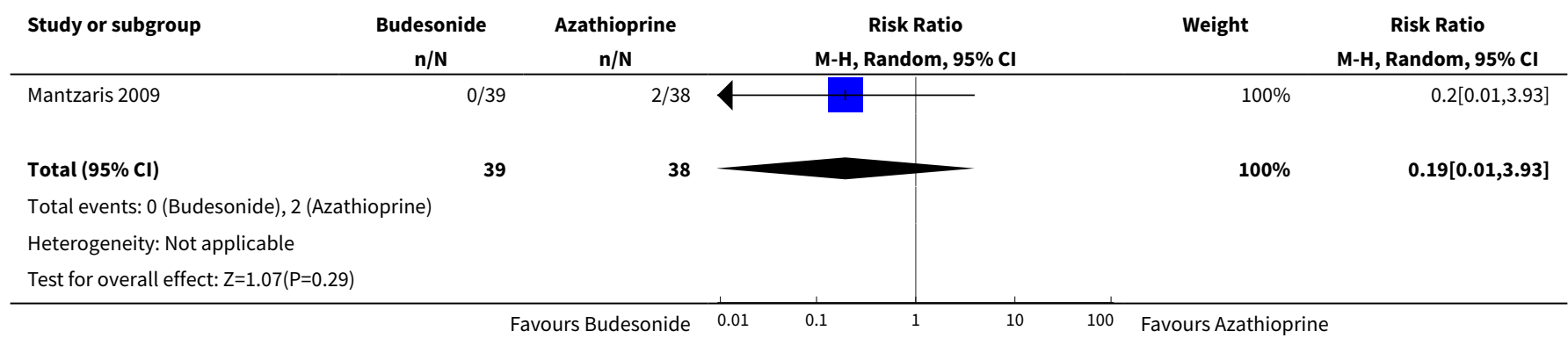

\section{AP PEN DICES}

\section{Appendix 1. Search strategies}

\section{Search sources}

A. Electronic searching

1. PubMed

2. MEDLINE (1950 - June 2014)

3. EMBASE (1980 - June 2014)

4. Cochrane Central Register of Controlled Trials (June 2014) 
5. Cochrane Inflammatory Bowel Disease and Functional Bowel Disorders (IBD/FBD) Group Specialised Trials Register

6. Ongoing trials were identified from the registry link http://ClinicalTrials.gov

B. Reference lists of trials and review articles identified using computer-assisted search (if electronic copies were available) and hand searching.

C. Proceedings from major gastroenterology meetings

American Gastroenterology Association, British Society of Gastroenterology, and United European Gastroenterology Week were manually searched from 2009 onwards.

Conference proceedings from Digestive Diseases Week were searched for 2009 using the Procite database of abstracts. Digestive Diseases Week proceedings from 2010 onwards are referenced in EMBASE.

D. Pharmaceutical and personal contacts

Relevant pharmaceutical companies were contacted for further information.

\section{Search terms}

\section{PubMed}

The PubMed search strategy combined all disease and budesonide terms with those used to identify randomized controlled trials to create the final set of keywords:

1. (crohn* OR IBD OR (inflammatory bowel disease*))

2. (budesonide OR entocort OR glucocorticoid ${ }^{\star}$ )

3. (singl* OR doubl* OR tripl* OR blind* OR mask* OR placebo* OR single-blind* OR double-blind* OR triple-blind ${ }^{\star} \mathrm{OR}^{\star}$ random OR (controlled clinical))

4. 1 and 2 and 3

\section{MEDLINE}

The MEDLINE search strategy combined all disease and budesonide terms with those used to identify randomized controlled trials to create the final set of keywords:

1. random\$.tw

2. factorial\$.tw

3. (crossover\$ or cross over\$ or cross-over\$).tw

4. placebo\$.tw

5. single blind.mp

6. double blind.mp

7. triple blind.mp

8. (singl\$ adj blind\$).tw

9. (double\$ adj blind\$).tw

10.(triple\$ adj blind\$).tw

11.assign\$.tw

12.allocat\$.tw

13.crossover procedure/

14.double blind procedure/

15.single blind procedure/

16.triple blind procedure/

17.randomized controlled trial/

18.or/1-17

19. (exp animal/ or animal.hw. or nonhuman/) not (exp human/ or human cell/ or (human or humans).ti.)

20.18 not 19

21.budesonide.mp or exp budesonide/

22. glucocorticoid ${ }^{\star}$.mp or exp glucocorticoid/

23.21 or 22

24.exp enteritis/ or inflammatory bowel disease*.mp or exp Crohn disease/

25.exp colon Crohn disease/ or crohn*.mp 
26.24 or 25

27.20 and 23 and 26

Additionally, articles currently being indexed for MEDLINE were identified using the following search strategy:

1. (crohn* OR CD OR IBD OR "inflammatory bowel disease*") AND (budesonide OR glucocorticoid*)

\section{EMBASE}

The EMBASE search strategy combined all disease and budesonide terms with those used to identify randomized controlled trials to create the final set of keywords:

1. random\$.tw

2. factorial\$.tw

3. (crossover\$ or cross over\$ or cross-over\$).tw

4. placebo\$.tw

5. single blind.mp

6. double blind.mp

7. triple blind.mp

8. (singl\$ adj blind\$).tw

9. (doubl\$ adj blind\$).tw

10.(tripl\$ adj blind\$).tw

11.assign\$.tw

12.allocat\$.tw

13.crossover procedure/

14. double blind procedure/

15.single blind procedure/

16.triple blind procedure/

17.randomized controlled trial/

18.or/1-17

19.(exp animal/ or animal.hw or nonhuman/) not (exp human/ or human cell/ or (human or humans).ti)

20.18 not 19

21.budesonide.mp or exp budesonide/

22. glucocorticoid ${ }^{\star} . \mathrm{mp}$ or exp glucocorticoid/

23.21 or 22

24.exp enteritis/ or inflammatory bowel disease*.mp or exp Crohn disease/

25.exp colon Crohn disease/ or crohn*.mp

26.24 or 25

27.20 and 23 and 26

\section{Cochrane Central Register of Controlled Trials}

The Cochrane Central Register of Controlled Trials search strategy combined all disease and budesonide terms to create the final set of keywords:

1. crohn* or (inflammatory bowel disease*) or IBD

2. budesonide or entocort or glucocorticoid ${ }^{\star}$

3. 1 and 2

\section{Procite}

The Procite search strategy combined all disease and budesonide terms:

1. (crohn* or CD or IBD OR "inflammatory bowel disease*") AND (budesonide OR glucocorticoid*)

ClinicalTrials.gov

The ClinicalTrials.gov search strategy combined all disease and budesonide terms to create the final set of keywords: 
1. (crohn* OR "inflammatory bowel disease*" OR IBD OR CD) AND (budesonide OR glucocorticoid*)

WHAT'S NEW

\begin{tabular}{lll}
\hline Date & Event & Description \\
\hline 9 April 2020 & Amended & $\begin{array}{l}\text { Correction of minor typographical error in the Abstract (main re- } \\
\text { sults). This does not affect the reporting of the results or the con- } \\
\text { clusions of the review. }\end{array}$ \\
\hline
\end{tabular}

\section{H I S T O R Y}

Protocol first published: Issue 1, 2001

Review first published: Issue 1, 2001

\begin{tabular}{lll}
\hline Date & Event & Description \\
\hline 4 June 2015 & Amended & Correction of data extraction error for ACTH outcome \\
\hline 17 July 2014 & New search has been performed & New literature search conducted on June 12, 2014. \\
\hline 17 July 2014 & $\begin{array}{l}\text { New citation required but conclusions } \\
\text { have not changed }\end{array}$ & Updated review with some new authors \\
\hline
\end{tabular}

\section{CONTRIBUTIONSOF AUTHORS}

MEK and AR were responsible for formulating the study question, carrying out the literature search, selecting and reviewing the studies, risk of bias assessment, performing the analyses and writing the manuscript.

CHS and EIB provided methodological expertise, IBD expert opinion, and reviewed the manuscript.

ARO, AHS, AMG, GGK provided IBD expert opinion and reviewed the manuscript.

\section{DECLARATIONS OF INTEREST}

M Ellen Kuenzig has no known declarations of interest to declare.

Ali Rezaie has no known declarations of interest to declare.

Cynthia Seow has served as a consultant and on advisory boards for Janssen Pharmaceuticals, Abbvie and Takeda. She has a grant through Janssen Pharmaceuticals. Dr. Seow has also provided lectures for Janssen Pharmaceuticals and Warner Chilcott. All of these activities are outside the submitted work.

Anthony Otley's institution is a participating site in an AstraZeneca funded FDA approved induction and maintenance clinical trials studying Entocort safety in pediatric Crohn's disease. Funds are paid to the institution, and the site $\mathrm{PI}(\mathrm{AO})$ does not receive payment directly. AO did not participate in the initial review of potentially eligible studies to determine whether they should be included or excluded.

Hillary Steinhart has received fee(s) from Janssen, Abbvie, Shire, Pendopharm, Pfizer, and Takeda for consultancy; and lecture fee(s) from: Janssen, Abbvie, Shire, Warner Chilcott, Aptalis, and Takeda. His institution has received grants or grants pending from Janssen, Abbvie, Pfizer, Amgen, Takeda and Actavis. All of these activities are outside the submitted work.

Anne Marie Griffiths has received fee(s) from Johnson and Johnson for board membership; fee(s) from Janssen Canada, Abbive Canada and Ferring Canada for consultancy; lecture fees from Abbvie Canada and Merck; and payment for development of educational presentations from Ferring. Her institution has received grants or grants pending from Johnson and Johnson and Abbvie Canada. All of these activities are outside the submitted work. 
Gilaad Kaplan has served as a speaker for Jansen, Merck, Schering-Plough, and Abbvie. He has participated in advisory board meetings for Jansen, Abbvie, Merck, and Schering-Plough. Dr. Kaplan has received research support from Merck, Abbvie, and Shire. All of these activities are outside the submitted work.

Eric Benchimol has no known declarations of interest to declare.

\section{SOURCES OF SUPPORT}

\section{Internal sources}

- MEK: University of Calgary, Calgary, Alberta, Canada.

- AR: Cedars Sinai Medical Center, Los Angeles, California, USA.

- CHS: University of Calgary, Calgary, Alberta, Canada.

- ARO: IWK Health Centre, Dalhousie University, Halifax, Nova Scotia, Canada.

- AHS: Inflammatory Bowel Disease Centre, Mount Sinai Hospital, University of Toronto, Toronto, Ontario, Canada.

- AMG: The Hospital for Sick Children, Toronto, Ontario, Canada.

- GGK: University of Calgary, Calgary, Alberta, Canada.

- EIB: The Children's Hospital of Eastern Ontario and University of Ottawa, Ottawa, Ontario, Canada.

\section{External sources}

- MEK: Achievers in Medical Science Recruitment Award, Eyes High Research Excellence Doctoral Scholarship, Queen Elizabeth II Graduate Scholarship, University of Calgary, Canada.

- AR: Canadian Institutes of Health Research Fellowship, Canada.

- GGK: CIHR New Investigator and Al-HS Population Health Investigator, Canada.

- EIB: Career Development Award from the Canadian Child Health Clinician Scientist Program, a Canadian Institutes of Health Research (CIHR) Strategic Training Program, Canada.

\section{INDEX TERMS}

\section{Medical Subject Headings (MeSH)}

Administration, Oral; Anti-Inflammatory Agents [*administration \& dosage]; Budesonide [*administration \& dosage]; Crohn Disease [ ${ }^{\star}$ drug therapy]; Induction Chemotherapy [methods]; Maintenance Chemotherapy [ ${ }^{\star}$ methods]; Randomized Controlled Trials as Topic; Risk; Secondary Prevention

\section{MeSH check words}

Humans 